\title{
Test Results for CSTR Test 4
}

\author{
D. D. Lee \\ J. L. Collins
}




\title{
DOCUMENT AVAILABILITY
}

Reports produced after January 1, 1996, are generally available free via the U.S. Department of Energy (DOE) Information Bridge:

Web site: http://www.osti.gov/bridge

Reports produced before January 1, 1996, may be purchased by members of the public from the following source:

\author{
National Technical Information Service \\ 5285 Port Royal Road \\ Springfield, VA 22161 \\ Telephone: 703-605-6000 (1-800-553-6847) \\ TDD: $703-487-4639$ \\ Fax: 703-605-6900 \\ E-mail: info@ntis.fedworld.gov \\ Web site: http://www.ntis.gov/support/ordernowabout.htm
}

Reports are available to DOE employees, DOE contractors, Energy Technology Data Exchange (ETDE) representatives, and International Nuclear Information System (INIS) representatives from the following source:

Office of Scientific and Technical Information

P.O. Box 62

Oak Ridge, TN 37831

Telephone: $865-576-8401$

Fax: 865-576-5728

E-mail: reports@adonis.osti.gov

Web site: http://www.osti.gov/contact.html

\begin{abstract}
This report was prepared as an account of work sponsored by an agency of the United States Government. Neither the United States government nor any agency thereof, nor any of their employees, makes any warranty, express or implied, or assumes any legal liability or responsibility for the accuracy, completeness, or usefulness of any information, apparatus, product, or process disclosed, or represents that its use would not infringe privately owned rights. Reference herein to any specific commercial product, process, or service by trade name, trademark, manufacturer, or otherwise, does not necessarily constitute or imply its endorsement, recommendation, or favoring by the United States Government or any agency thereof. The views and opinions of authors expressed herein do not necessarily state or reflect those of the United States Government or any agency thereof.
\end{abstract}


ORNL/TM-2001/8

Chemical Technology Division

\title{
Test Results for CSTR Test 4
}

D. D. Lee and J. L. Collins

Date Published: April 2001

\author{
Prepared by \\ OAK RIDGE NATIONAL LABORATORY \\ P.O. Box 2008 \\ Oak Ridge, Tennessee 37831-6285 \\ managed by \\ UT-BATTELLE, LLC \\ for the \\ U.S. DEPARTMENT OF ENERGY \\ under contract DE-AC05-00OR22725
}





\section{CONTENTS}

LIST OF FIGURES $\quad$ Page

LIST OF TABLES …............................................................................................... vii

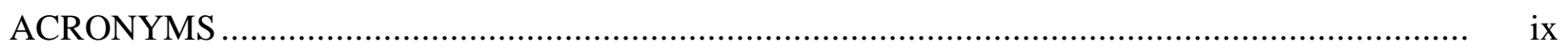

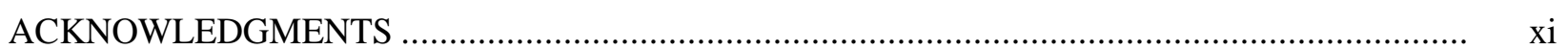

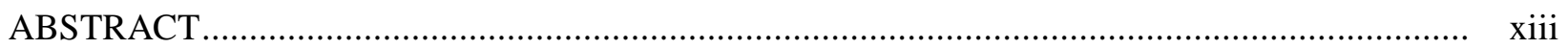

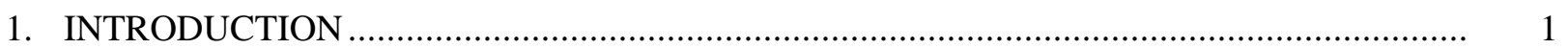

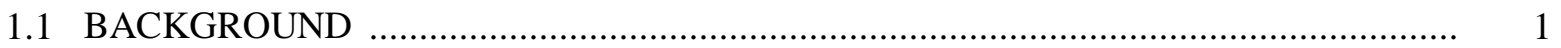

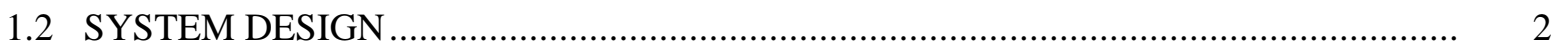

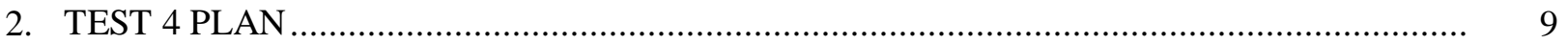

2.1 TEST DESIGN

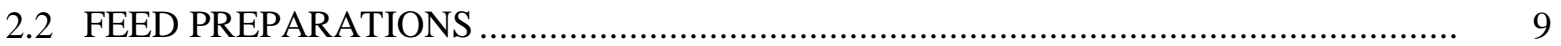

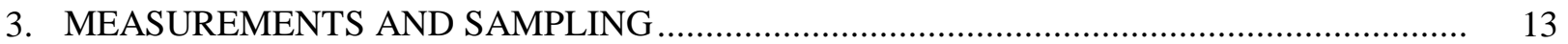

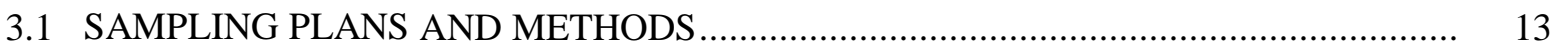

3.2 MEASURING AND TEST EQUIPMENT .......................................................... 13

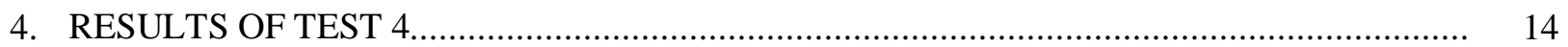

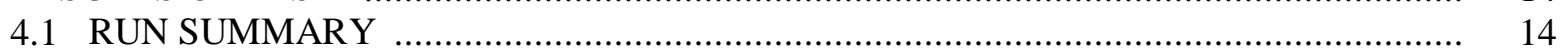

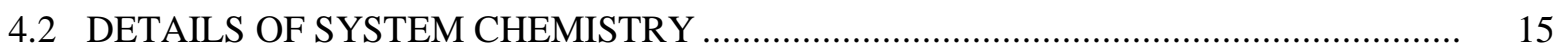

4.2.1 Cesium and Strontium Decontamination of Test 4 Feed .................................... 15

4.2.2 HPLC Analyses for TPB Decomposition Products ........................................... 20

4.2.3 ICP-AES Analyses for Potassium and Boron ..................................................... 25

4.2.4 Benzene Production Rate as a Measure of TPB Decomposition............................. 25

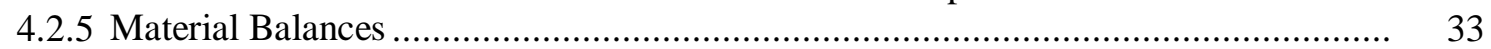

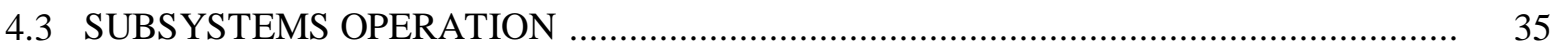

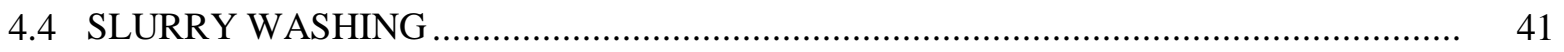

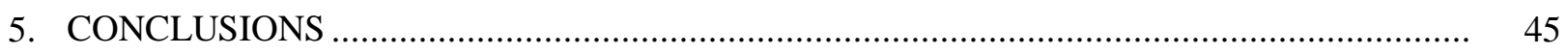

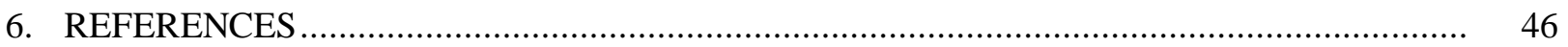





\section{LIST OF FIGURES}

Figure

Page

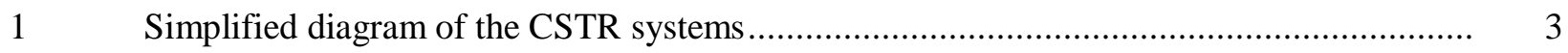

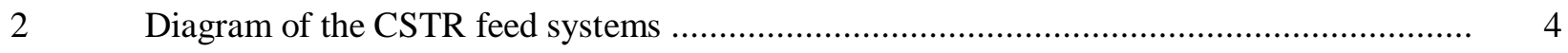

$3 \quad$ Redesigned slurry concentration filter system .................................................. 5

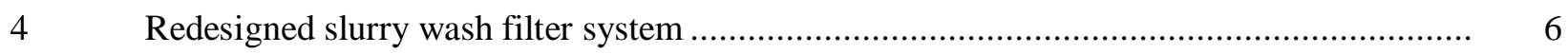

$5 \quad$ Flowsheet for the benzene monitoring system ....................................................

$6 \quad$ Valves and piping for the benzene monitoring system ........................................... 8

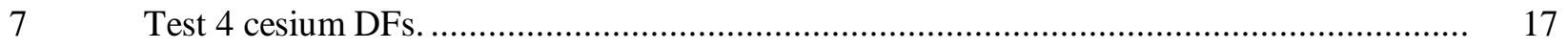

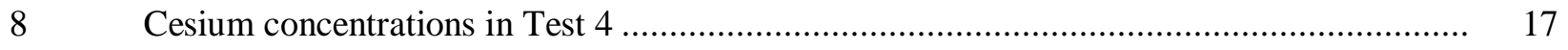

9 Cesium concentrations in Test 4 concentrate filtrate showing filtration differences............. 18

10 Cesium concentrations in Test 4, after CSTR 1 ........................................................ 18

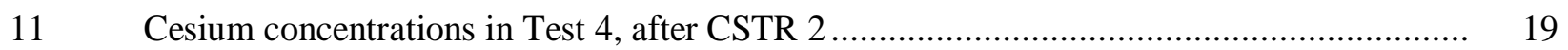

12 Cesium concentrations in Test 4, after Slurry Concentrating Tank................................ 19

$13 \quad$ Analytical concentrations of ${ }^{85} \mathrm{Sr}$ in Test 4 process vessels....................................... 20

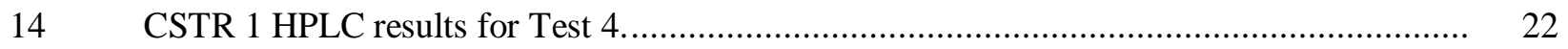

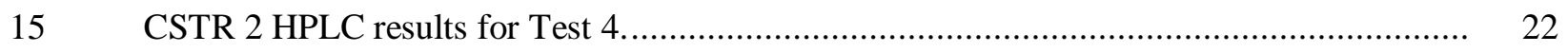

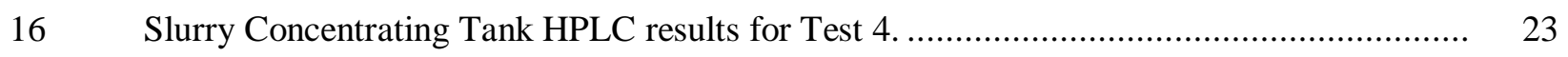

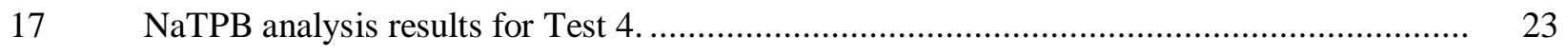

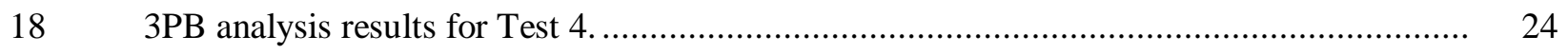

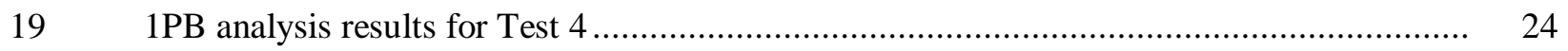

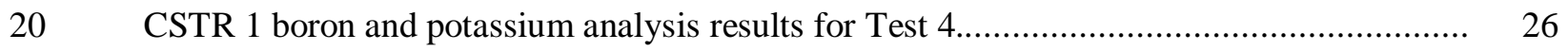

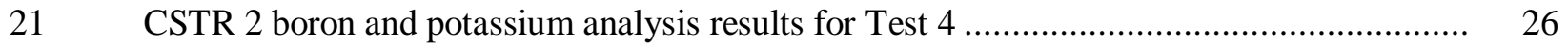

22 Concentrate filtrate boron and potassium analysis results for Test 4 ............................. 27

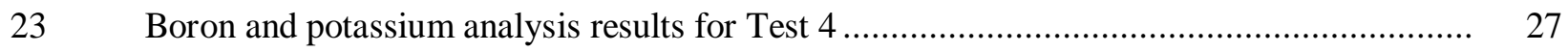

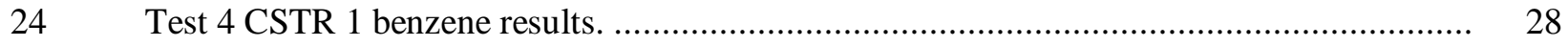


26 CSTR 2 HPLC results for Test 4, subtracting CSTR 1 values from those in CSTR 2..........

27 Test 4 Slurry Concentrating Tank benzene results

28 Concentrate filtrate benzene results for Test 4, subtracting CSTR 2 values

from those in the filtrate.

29 Test 4 benzene analyzer results. Four-day overview

30 Test 4 benzene analyzer results. Response during benzene addition.

31 Test 4 benzene analyzer results. Response during $45^{\circ} \mathrm{C}$ operation.

32 Test 4 feed materials flow balance showing overall test average flow rate.

33 Test 4 cumulative masses fed to CSTR 1

$34 \quad$ TPB and MST feed rates from their balances during $25^{\circ} \mathrm{C}$ operation. ............................ 36

35 TPB and MST feed rates from their balances during heatup and $45^{\circ} \mathrm{C}$ operation................ 36

$36 \quad$ TPB and MST feed rates from their balances during $45^{\circ} \mathrm{C}$ operation. ............................ 37

37 CSTR 1 operation during feeding from recycle washer tank ........................................ 37

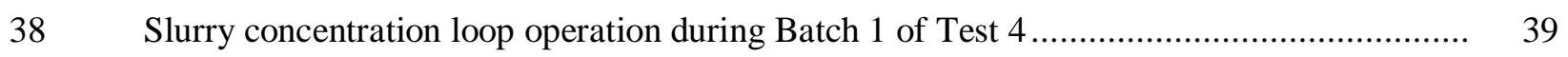

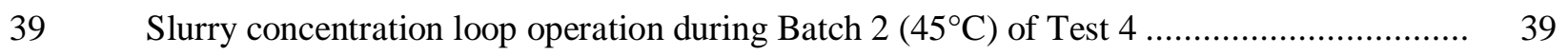

$40 \quad$ Slurry concentration loop filter backpulse during first batch concentration ...................... 40

41 CSTRs and Slurry Concentrating Tank temperatures during operation at $45^{\circ} \mathrm{C} \ldots \ldots \ldots \ldots \ldots \ldots . . . . . . .40$

42 Close-up view of CSTRs and Slurry Concentrating Tank temperatures during operation at $45^{\circ} \mathrm{C}$

$43 \quad$ Nitrite and TPB concentrations during Test 4 slurry washing $\left(25^{\circ} \mathrm{C}\right.$ batch and $45^{\circ} \mathrm{C}$ batch). 


\section{LIST OF TABLES}

Table

Page

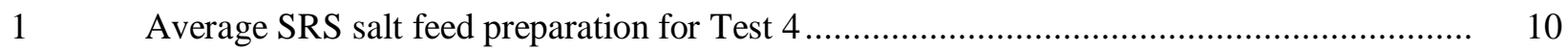

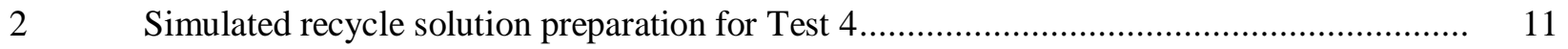

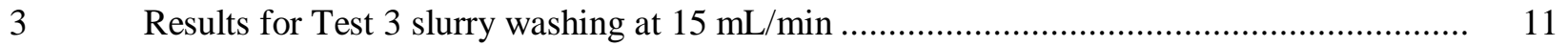

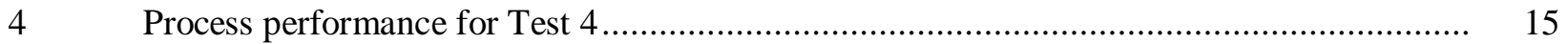

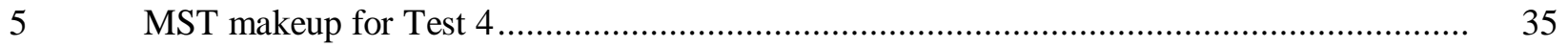

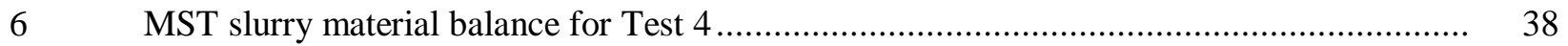

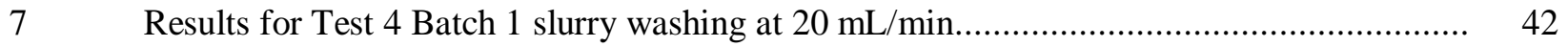

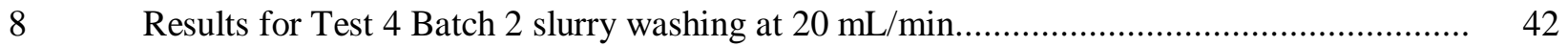

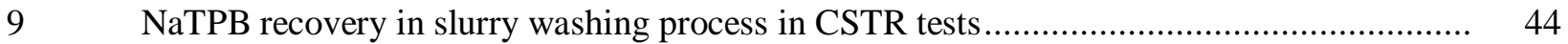





\section{ACRONYMS}

\begin{tabular}{|c|c|}
\hline ALARA & as low as reasonably achievable \\
\hline BDL & below the detection limit \\
\hline CERS & Chemical and Energy Research Section \\
\hline CsTPB & cesium tetraphenylborate \\
\hline CSTR & continuous-flow stirred-tank reactor \\
\hline DF & decontamination factor \\
\hline FTIR & Fourier transform infrared analyzer \\
\hline HLW & high-level waste \\
\hline HPLC & high-performance liquid chromatography \\
\hline ICP & inductively coupled plasma \\
\hline ICP-MS & inductively coupled plasma-mass spectroscopy \\
\hline КТРВ & potassium tetraphenylborate \\
\hline MST & monosodium titanate \\
\hline NaTPB & sodium tetraphenylborate \\
\hline NIST & National Institute of Standards and Technology \\
\hline ORNL & Oak Ridge National Laboratory \\
\hline PBs & $1 \mathrm{~PB}, 2 \mathrm{~PB}$, and $3 \mathrm{~PB}$ decomposition products of $\mathrm{TPB}$ \\
\hline$P \& E$ & Plant and Equipment Division (ORNL) \\
\hline QA & quality assurance \\
\hline RMAL & Radioactive Materials Analytical Laboratory \\
\hline SP & sample port \\
\hline SPP & Salt Waste Processing Program \\
\hline SRL & Savannah River Laboratory \\
\hline SRS & Savannah River Site \\
\hline SRTC & Savannah River Technology Center \\
\hline STTP & Small-Tank Tetraphenylborate Process \\
\hline TPB & tetraphenylborate \\
\hline TTP & technical task plan \\
\hline WAC & waste acceptance criteria \\
\hline WSRC & Westinghouse Savannah River Company \\
\hline 3PB & triphenylborane \\
\hline $2 \mathrm{~PB}$ & diphenylborinic acid \\
\hline $1 \mathrm{~PB}$ & phenylboronic acid \\
\hline
\end{tabular}





\section{ACKNOWLEDGMENTS}

The authors wish to thank their colleagues at the Westinghouse Savannah River Company and Savannah River Technology Center for the invaluable assistance they provided in ensuring that the 20-L CSTR Demonstration Program was a success. In addition to participating in the actual tests, the Savannah River Salt Processing Program Team provided excellent design, operational, and chemistry guidance. Some of the many key contributors were (in alphabetical order) Mark Barnes, Seth Campbell, Joe Carter, Hank Elder, Sam Fink, Jim Firth, Rick Fowler, Harry Harmon, Roy Jacobs, Rocci Norcia (the Control Company), Reid Peterson, Michael Poirier, Ken Rueter, Steve Schlahta, Tony Tipton, and Walter Tamosaitis.

The efforts of the ORNL staff were also greatly appreciated. Kim Anderson, Bill Chase, Bob Cummins, Jim Hewitt, Rodney Hunt, Hal Jennings, Tim Kent, Steve Richardson, Paul Taylor, Jim Travis, and Betty Evans of the Chemical Technology Division participated in preparing and conducting the tests. Max Cronan, Greg Knox, and other members of the Plant and Equipment Division, as well as Vern McClain, Don Raby, and members of the Instrumentation and Controls Division, did an excellent job in the construction and installation of the experimental equipment in the hot cells. John Keller, Joe Giaquinto, and the technicians at the Radioactive Materials Analysis Laboratory conducted the hundreds of required analyses in a timely manner. John Slaten and the staff of Radiation Protection provided excellent support through the long days and nights of continuous operations. The authors also appreciate the efforts of Richard Shoun for his guidance on safety-related matters and the ALARA Plan, and Bob Jubin and Phil McGinnis for their managerial help and support, Roger Jones for his assistance with the QA plan, and Beulah Brock for her considerable help and patience in handling the large volume of paperwork that this project entailed.

This study was sponsored by the Tanks Focus Area of DOE's EM-50 under contract DE-AC05-00OR22725 with UT-Battelle, LLC. 



\begin{abstract}
The goal of the Savannah River Salt Waste Processing Program (SPP) is to evaluate and select the most effective technology for the treatment of high-level waste salt solutions presently being stored in underground storage tanks at the United States Department of Energy Savannah River Site (SRS) in Aiken, South Carolina. One of the three technologies currently being developed as part of this effort is the Small-Tank Tetraphenylborate Process (STTP). This process uses sodium tetraphenylborate (NaTPB) to precipitate and remove radioactive cesium from the waste and monosodium titanate (MST) to sorb and remove radioactive strontium and actinides. Oak Ridge National Laboratory is demonstrating this process at the 1:4000 scale using a 20-L-capacity continuous-flow stirred tank reactor (CSTR) system. Since March 1999, four operating campaigns of the 20-L CSTR have been conducted. The ultimate goal is to verify that this process, under certain extremes of operating conditions, can meet the minimum treatment criteria necessary for processing and disposal at the Savannah River Saltstone Facility. The waste acceptance criteria (WAC) for ${ }^{137} \mathrm{Cs},{ }^{90} \mathrm{Sr}$, and total actinides are $<40 \mathrm{nCi} / \mathrm{g},<40 \mathrm{nCi} / \mathrm{g}$, and $<18 \mathrm{nCi} / \mathrm{g}$, respectively. However, to allow for changes in process conditions, SPP is seeking a level of treatment that is about $50 \%$ of the WAC. The bounding separation goals for ${ }^{137} \mathrm{Cs}$ and ${ }^{90} \mathrm{Sr}$ are to obtain decontamination factors (DFs) of 40,000 (99.998\% removal) and 26 (96.15\% removal), respectively. The DF is defined as the concentration of contaminant in the waste divided by the concentration of contaminant in the effluent stream.

Tests 1 and 2 were conducted in June and July 1999, and the results are documented in ORNL/TM-1999/234. These initial tests, using simulants traced with radioactive materials, verified that the STTP process could achieve the necessary cesium, strontium, and actinide decontamination under standard operating conditions, with and without the recovery and recycle of the excess TPB that was not precipitated with potassium and cesium. TPB decomposition, the major side reaction of the process, did not occur in Test 2 despite the addition of materials [SRS synthetic sludge and modified Enhanced Comprehensive Catalyst (ECC)] that were known to cause TPB to degrade. Test 3 was a 72-h demonstration that was conducted during August 2000. The objectives were to examine the effectiveness of an improved foam suppressant (IIT B52) in minimizing foam formation and to determine if its presence had a deleterious effect on the removal of $\mathrm{Cs}, \mathrm{Sr}$, and $\mathrm{U}$ from simulated waste. Test 3 was operated long enough to provide about nine system turnovers. The DFs for Cs, Sr, and U obtained for the filtrate from the Slurry Concentrating Tank were $>40,000, \sim 50$, and $\sim 5$, respectively, which exceeded the WAC standards. No foaming problems were experienced during the test, and the foam suppressant had no apparent negative effect on the separations process. High-performance liquid chromatography (HPLC) analyses indicated that no measurable NaTPB decomposition occurred during the test. The results of Test 3 are documented in CERS/SR/TPB/011.

Test 4 was a 130.3-h demonstration that was conducted in October 2000. As in Test 3, foam suppressant IIT B52 was added to the system vessels to minimize foam formation. The primary goal was to verify that the STTP process could achieve and maintain the necessary cesium decontamination while TPB was actively decomposing. An improved SRS catalyst system, consisting of $\mathrm{Pd}(0)$ on alumina powder, $\mathrm{Hg}(\mathrm{II})$ salt, phenylboronic acid (1PB), and benzene, was continuously added during the test, which successfully initiated and sustained TPB decomposition. The rate of TPB decomposition was determined by analyzing process samples for TPB degradation products using reverse-phase HPLC. The rate of decomposition was also sensitive to temperature.
\end{abstract}


The system vessels were controlled at $25^{\circ} \mathrm{C}$ during the first $76 \mathrm{~h}$ of operation. The temperature was subsequently increased to $45^{\circ} \mathrm{C}$ over the next $13 \mathrm{~h}$ and then maintained at that temperature for the remainder of the test. As expected, the TPB decomposition rate increased at the elevated temperatures. At the end of the test, about $4.2 \%$ of the total TPB in the first CSTR vessel was being decomposed. This behavior was also confirmed by on-line Fourier transform infrared (analyzer) measurement of benzene from the vapor space of each vessel. Even with TPB being decomposed by the off-normal conditions of this test, the DF for ${ }^{137} \mathrm{Cs}$ obtained for the filtrate from the Slurry Concentrating Tank ranged from 47,000 to 646,000, exceeding the WAC standard.

Overall, the system control and hydraulic behavior were good, with no foam formation or problems being detected in any of the vessels. More than $162 \mathrm{~L}$ of radioactive, simulated waste was treated during the test, and $\sim 218 \mathrm{~L}$ of decontaminated filtrate was collected. About $13 \mathrm{~L}$ of 10 wt \% TPB precipitate/MST slurry was collected and washed to recover the excess TPB (that was not precipitated as potassium and cesium). Only about 10 to $11 \%$ of the available TPB was recovered during slurry washing with water. 


\section{INTRODUCTION}

\subsection{BACKGROUND}

The Small-Tank Tetraphenylborate Process (STTP) is one of three separations processes currently being examined by the Savannah River High-Level Waste (HLW) Salt Waste Processing Program (SPP) as an alternative to the In-Tank Precipitation Process for treatment of highly radioactive Savannah River Site (SRS) tank waste. The ultimate goal of the process is to decontaminate the SRS salt waste so that it meets the waste acceptance criteria (WAC) for processing and disposal at the Savannah River Saltstone Facility. The $\mathrm{WAC}$ for ${ }^{137} \mathrm{Cs},{ }^{90} \mathrm{Sr}$, and alpha are $<40 \mathrm{nCi} / \mathrm{g},<40 \mathrm{nCi} / \mathrm{g}$, and $<18 \mathrm{nCi} / \mathrm{g}$, respectively. However, to allow for changes in process conditions, the SPP is seeking a level of treatment that is about $50 \%$ of the WAC. Supernatants in "high- $\mathrm{OH}^{-}$" SRS tanks that are $6.4 \mathrm{M}$ in $\mathrm{Na}^{+}$have cesium concentrations in the range of $0.000415 \mathrm{M}$. Cesium concentrations for average SRS waste with the same $\mathrm{Na}^{+}$concentration are in the range of $0.000157 \mathrm{M}$. The ${ }^{137} \mathrm{Cs}$ radioactivity levels for these wastes are 1.1 and $0.41 \mathrm{Ci} / \mathrm{L}$, respectively.

A 1:4000-scale, 20-L continuous-flow stirred-tank reactor (CSTR) system was designed and fabricated at Oak Ridge National Laboratory (ORNL) for development of this process. The goal of the 20-L CSTR test program is to evaluate the performance of the 20-L CSTR system under conditions that simulate the anticipated full-scale operation of the system. The basic chemistry of the process makes use of tetraphenylborate (TPB) to remove cesium by precipitation and monosodium titanate (MST) to remove strontium and actinides ( $\mathrm{Pu}, \mathrm{Np}$, and $\mathrm{U}$ ) by sorption. The CSTR system was to be operated in a contained and shielded hot cell environment to allow the use of radioactive materials. Testing of the CSTR system would determine if this approach could (1) provide the necessary cesium, strontium, and actinide separations needed for treatment of the SRS salt waste; (2) perform satisfactorily with an improved antifoam agent; and (3) perform satisfactorily while active decomposition of TPB was taking place with and without the recovery and recycle of unreacted TPB.

Test 1a (Tests 1b and 1c were not needed) and Test 2 were conducted in FY 1999 and met performance objectives in verifying that the required separations of cesium, strontium, and actinides could be provided by this process. ${ }^{1}$ Test 3 was a 72-h demonstration conducted in FY 2000 to examine the effectiveness of an improved foam suppressant (IITB52) in minimizing foam formation and to determine if its presence had a damaging effect on the removal of $\mathrm{Cs}, \mathrm{Sr}$, and $\mathrm{U}$ from simulated waste. ${ }^{2}$ There was no evidence of excessive foam formation indicated in slurry samples taken or by any operational difficulties. Cesium, strontium, and uranium removal were not significantly impacted by the antifoam, and the DFs were comparable to those obtained in earlier tests. Slurry washing at the end of the test showed no apparent effect of the antifoam on TPB recovery as compared with Tests 1a and 2.

The objective of Test 4 was to demonstrate that acceptable system performance could be maintained while TPB was decomposing. The STTP must remove cesium from the salt to achieve the WAC requirement of $40 \mathrm{nCi}{ }^{137} \mathrm{Cs} / \mathrm{g}$. This requires a decontamination factor (DF) of $\sim 18,000(99.994 \%$ cesium removal) for the 1.1-Ci/L "high-OH" supernatant and a DF of $~ 7000$ (99.986\% cesium removal) for the $0.41-\mathrm{Ci} / \mathrm{L}$ average SRS supernatant. The SPP goal is to achieve a DF of 40,000 (99.998\% cesium removal), which would successfully treat supernatants with ${ }^{137} \mathrm{Cs}$ concentrations up to $2.44 \mathrm{Ci} / \mathrm{L}$. Only a few SRS tanks have concentrations that high. 


\subsection{SYSTEM DESIGN}

The apparatus used in the test system was sized and designed to provide reliable data for scaleup to larger systems. All feeds are introduced into CSTR 1, and the degree of decontamination of the process stream in any vessel is always defined based on the feed to this reactor. Most of the precipitation of cesium takes place in CSTR 1. CSTR 2 provides extended residence time for some additional precipitation to occur. The primary role of CSTR 2 in the process is to provide residence time for the MST to sorb the actinides present in the real waste. The test system, which is located in Hot Cell B, Building 4501, includes two CSTRs in series, each with a 15-L working volume, a slurry concentration tank with a cross-flow filter to concentrate the slurry, a concentrated-slurry washing tank with a cross-flow filter, and various tanks and pumps to integrate the operation. Two 55-gal feed tanks with mixing systems were located in Hot Cell C. Figure 1 shows a simplified process flowsheet for the system.

Figures 2-6 provide the updated flowsheets for the TPB process test system in Hot Cell B. Figure 2 shows the CSTR feed systems; Fig. 3, the slurry concentration system; and Fig. 4, the slurry wash system. Figures 5 and 6 show the CSTR benzene monitoring flowsheet. Note that the benzene analyzers are on a platform on the wall adjacent to Hot Cell B in room 126C. 


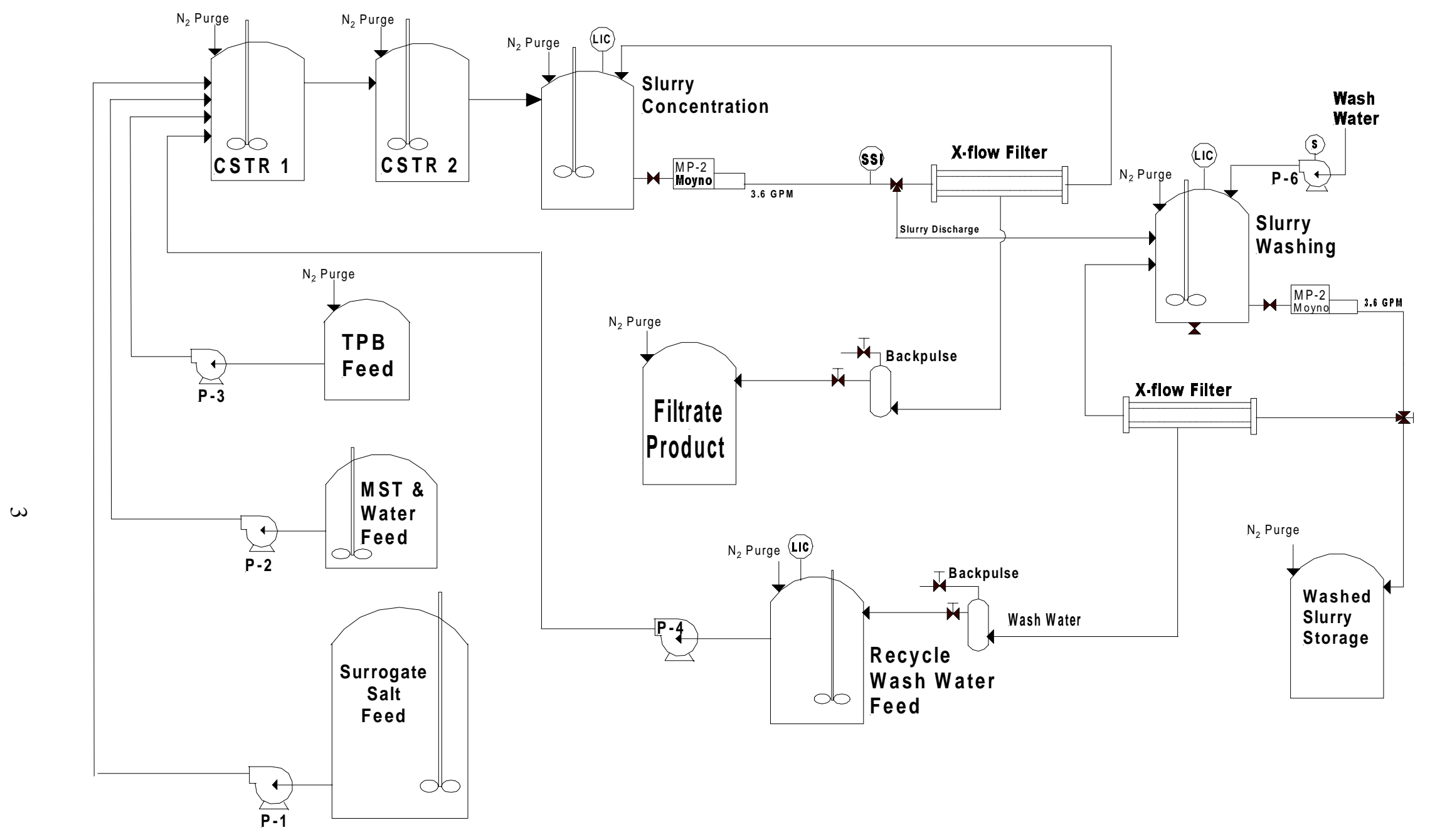

Fig. 1. Simplified diagram of the CSTR systems. 


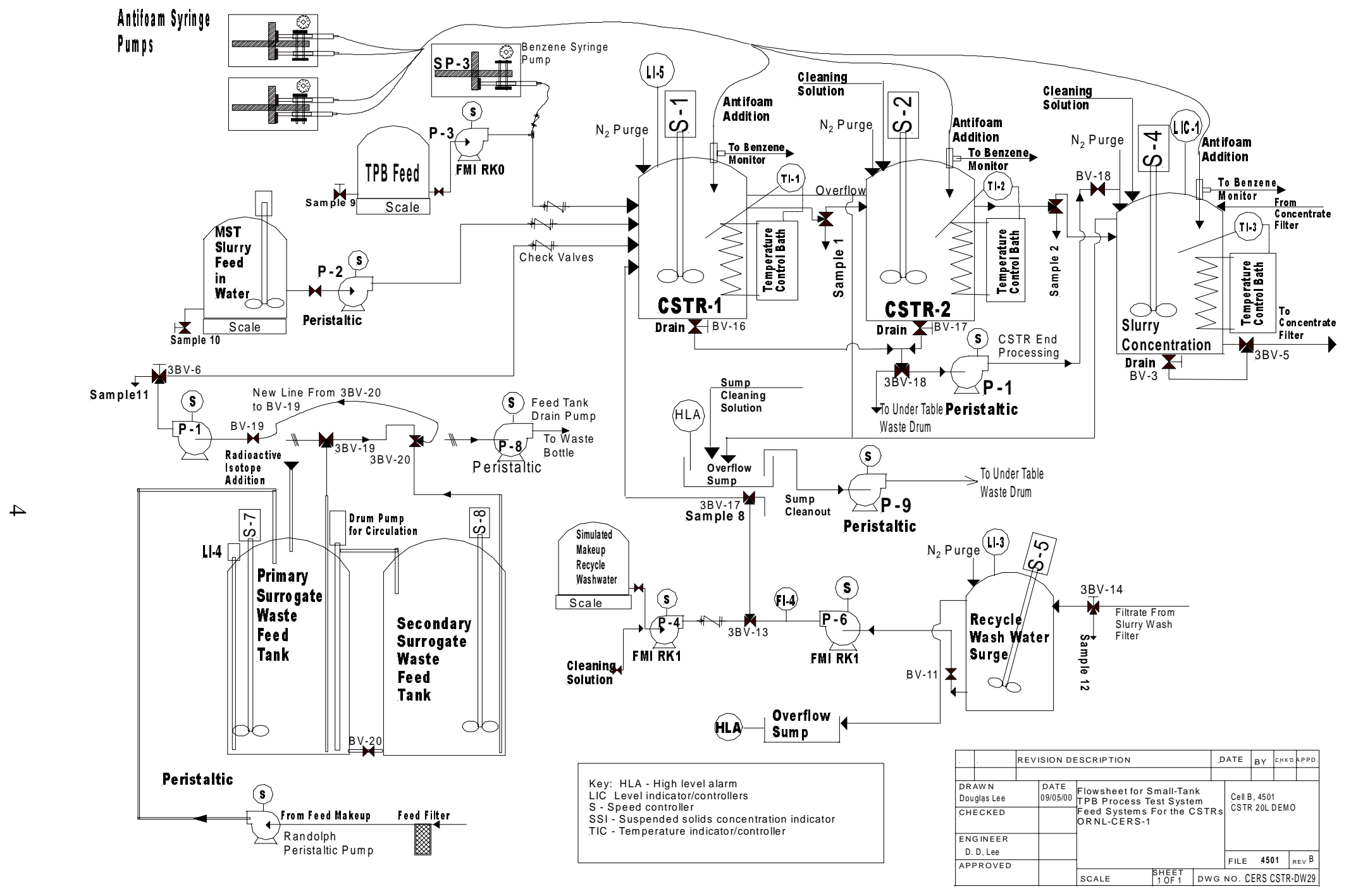

Fig. 2. Diagram of the CSTR feed systems. 


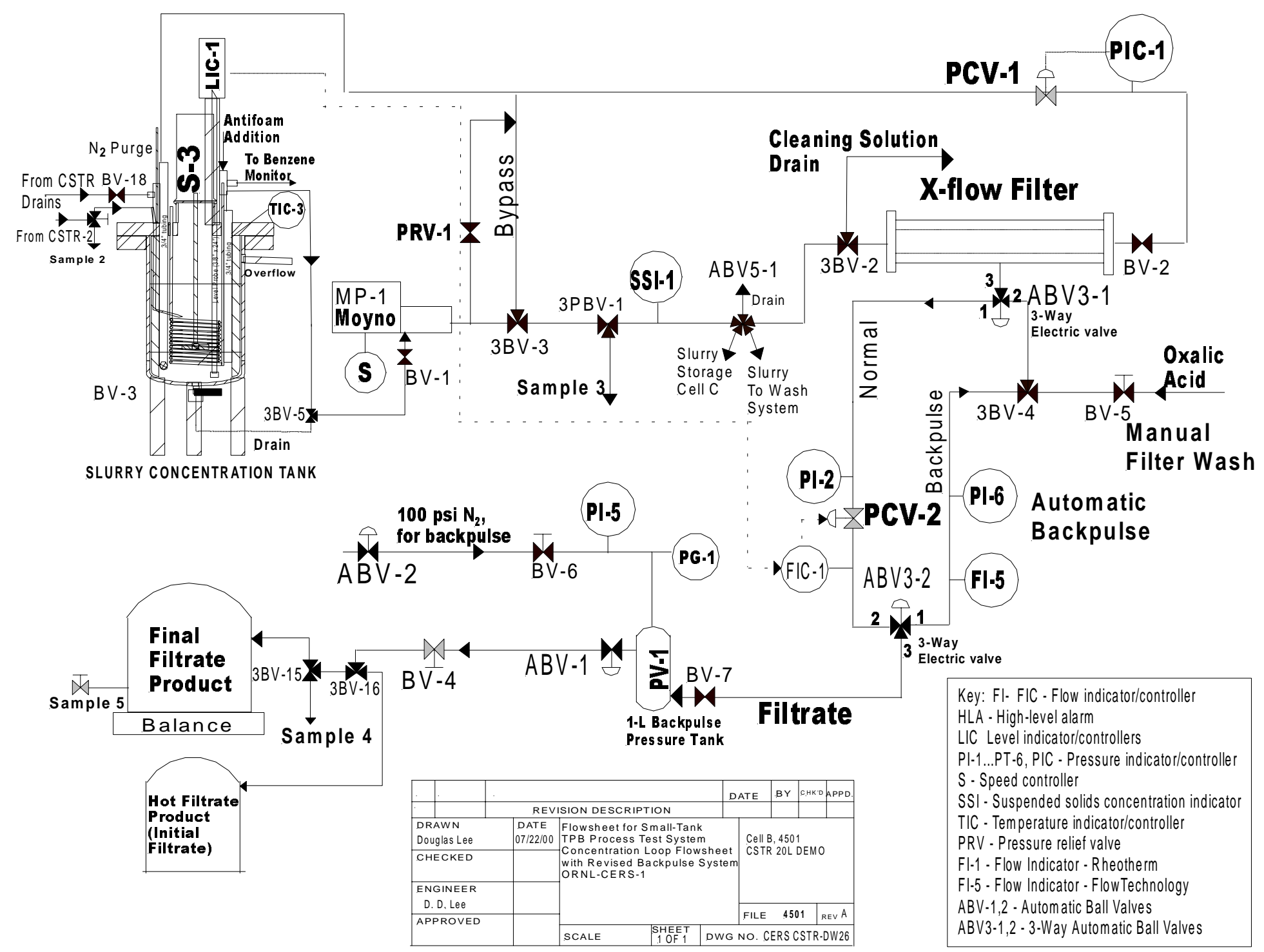

Fig. 3. Redesigned slurry concentration filter system. 


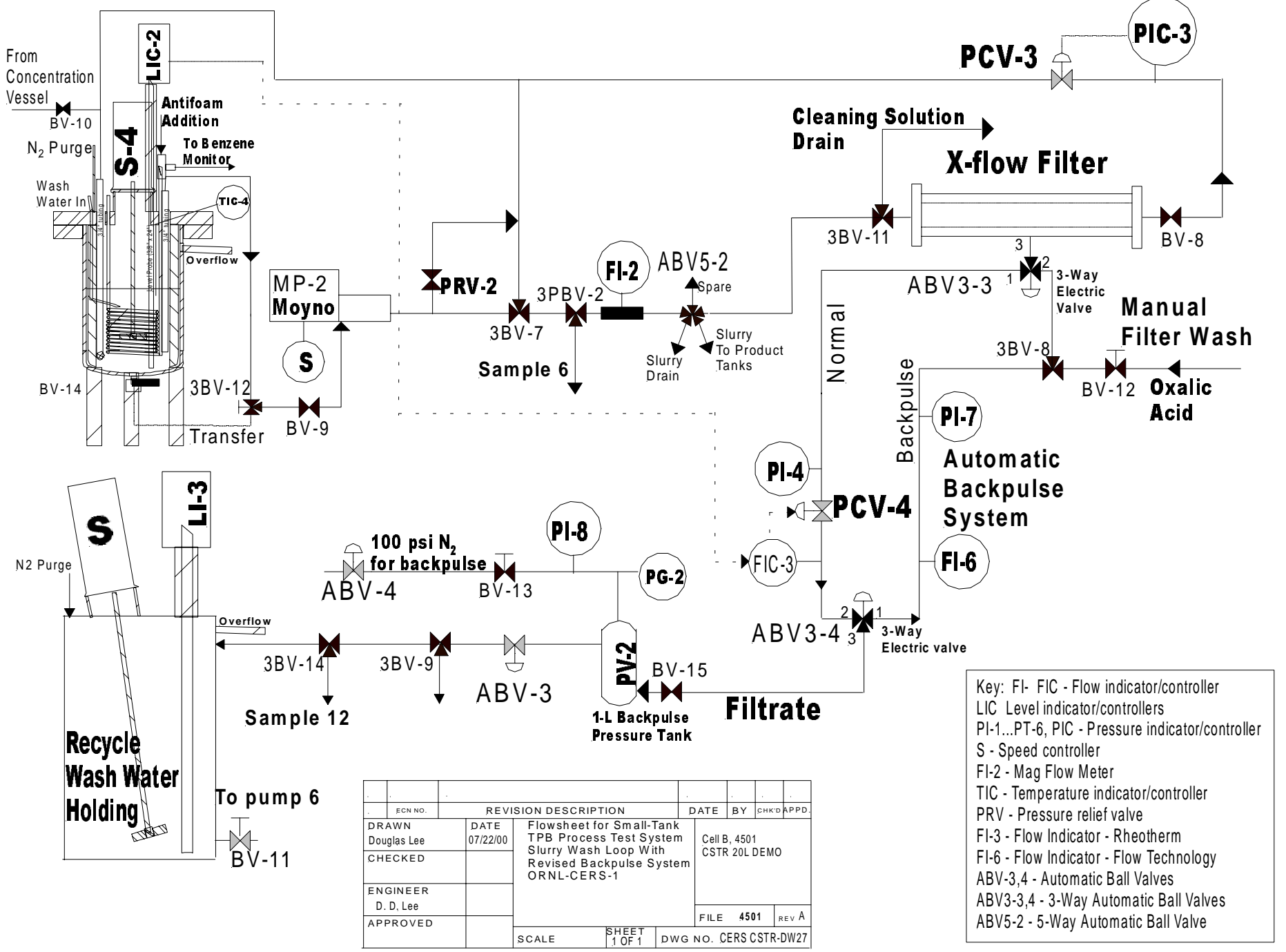

Fig. 4. Redesigned slurry wash filter system. 


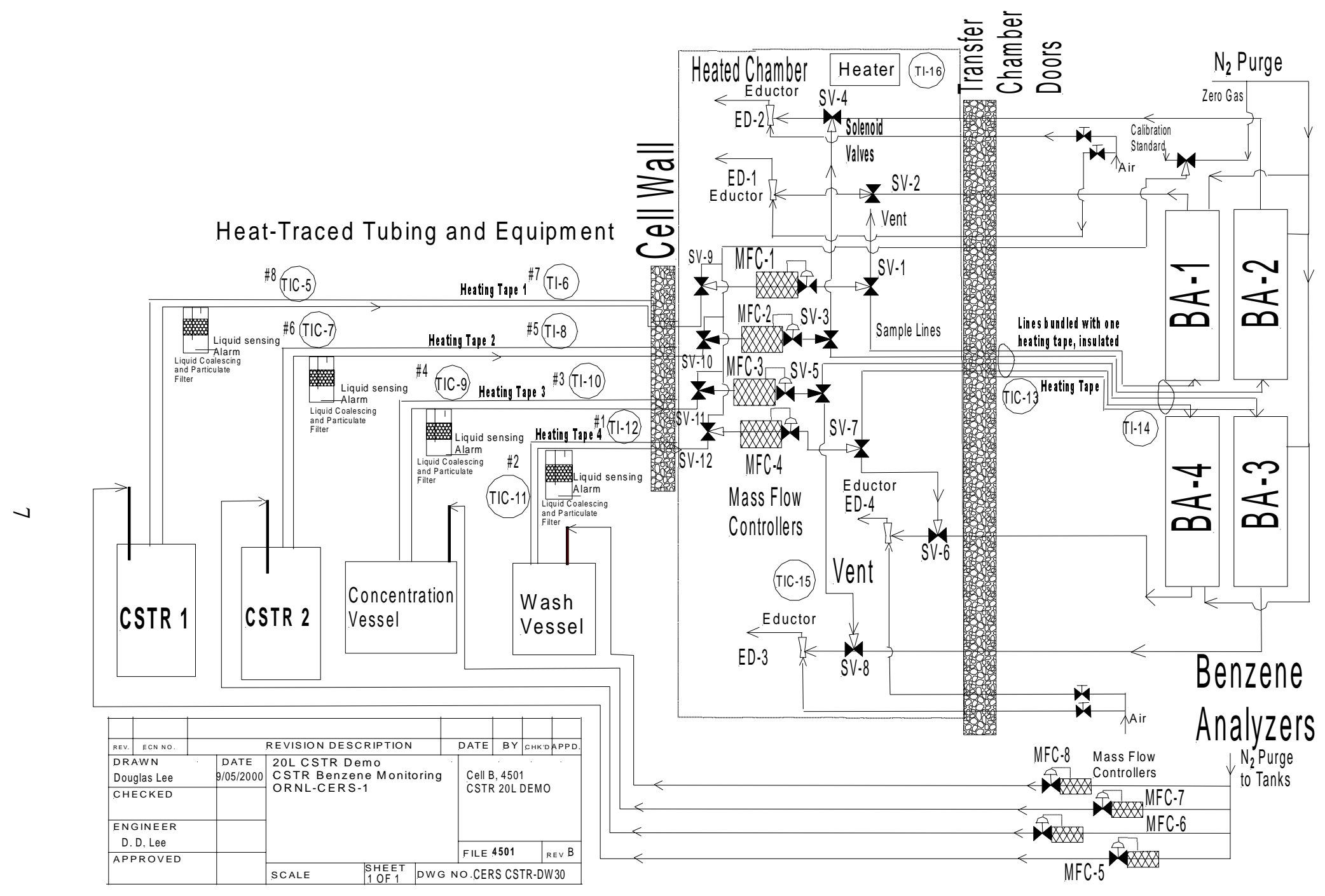

Fig. 5. Flowsheet for the benzene monitoring system. 
Cell Transter Compartment

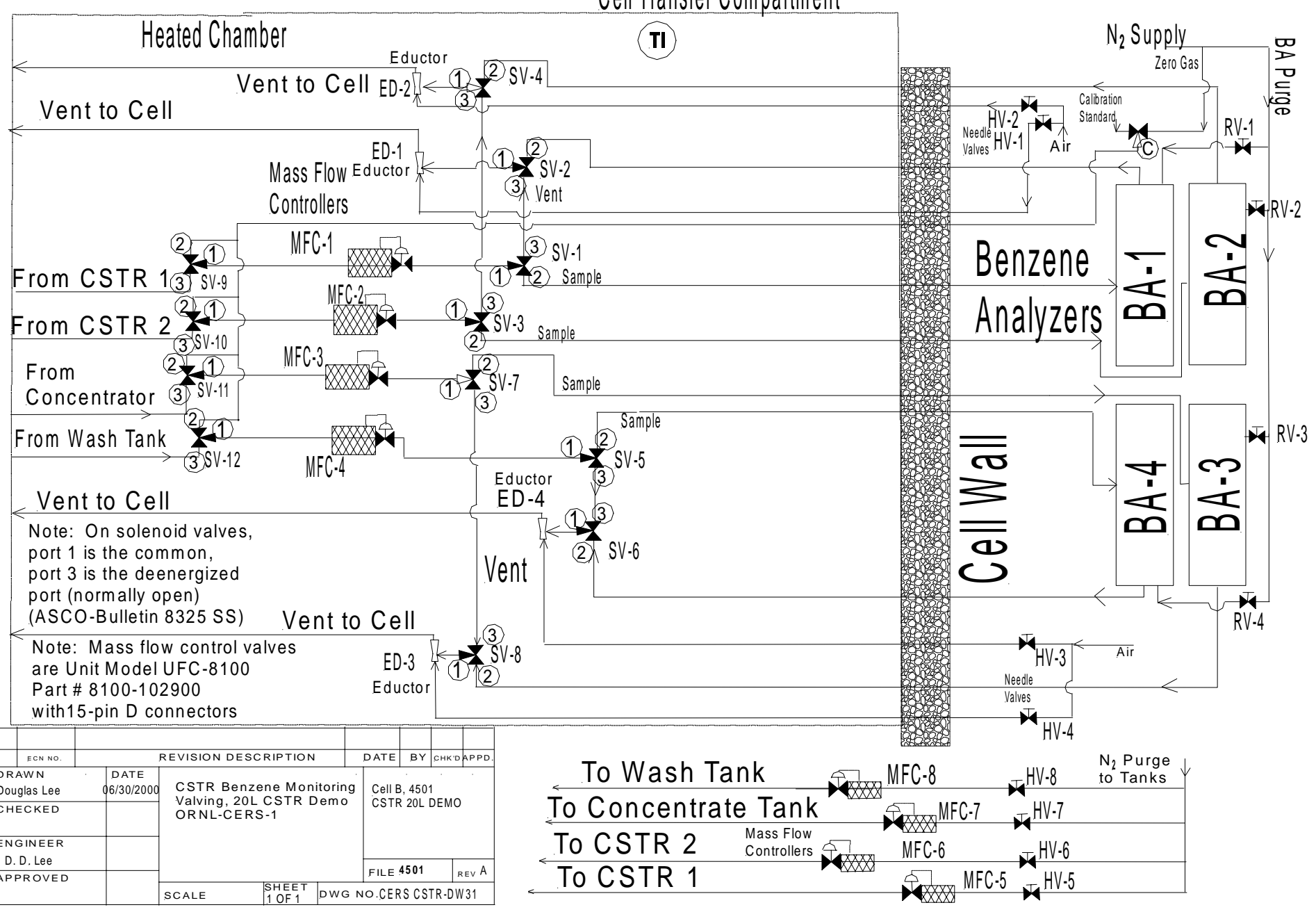

Fig. 6. Valves and piping for the benzene monitoring system. 


\section{TEST 4 PLAN}

\subsection{TEST DESIGN}

The primary goal of Test 4 was to evaluate the contaminant removal performance of the CSTR system while TPB was actively decomposing. Test 4 was planned to be a single-pass (no recycle of recovered TPB), 80-h test that provided about ten volume turnovers in the CSTRs. A more aggressive catalyst system was used to cause TPB decomposition and determine if a sustained cesium DF could be maintained under these flowsheet conditions. The catalyst was designed by SRTC (Mark Barnes et al., Recommendation of Catalyst System and Delivery for ORNL 20-L Testing, SRT-LWP-2000-00126, August $2000^{3}$ ) to provide a " $3 X$ " ("X" being the expected catalyst concentration based on historical data) catalyst concentration in the process fluids of the CSTRs. The catalyst consisted of palladium (5\% on alumina powder), mercury $\left[\mathrm{Hg}\left(\mathrm{NO}_{3}\right)_{2} \cdot \mathrm{H}_{2} \mathrm{O}\right]$, phenylboronic acid (1PB), and benzene, which were to be added with the feed materials to CSTR 1. The TPB decomposition goal was to obtain a benzene generation rate in the Slurry Concentrating Tank of about $10 \mathrm{mg} /(\mathrm{L} \cdot \mathrm{h})$, which would provide a benzene concentration of about $400 \mathrm{ppm}$ in the purge gas (assuming no holdup of benzene in the process fluids).

A secondary goal of Test 4 was to operate at a higher temperature $\left(45^{\circ} \mathrm{C}\right)$ to test system performance under catalytic conditions after the initial goal was reached. The plan involved a 12-h temperature ramp up to $45^{\circ} \mathrm{C}$ and continued operation at $45^{\circ} \mathrm{C}$ for the time required to process a second batch of TPB precipitate slurry (10 wt \% solids) or until it was clear that the required cesium DF could not be maintained. Test 4 was started with both CSTRs filled with the process fluids remaining in the CSTRs at the end of Test 3 and with the Slurry Concentrating Tank drained and rinsed.

The agitators in the two CSTRs were run at speeds in the range of $650-850 \mathrm{rpm}$ for this test. The concentration of the IITB52 antifoam agent (Batch 7-31-2000, product index ANAEPG, with an ethylene-based solvent) in the salt feed slurry was maintained at 50 ppmv in the CSTRs and 100 ppmv in the Slurry Concentrating Tank by continuously pumping with syringe pumps. As in the previous tests, the concentration of ${ }^{137} \mathrm{Cs}$ in the salt feed (average SRS recipe) was $\sim 8 \mathrm{mCi} / \mathrm{L}$, which was diluted by other feeds to $\sim 6.5 \mathrm{mCi} / \mathrm{L}$ of slurry in the CSTRs.

\subsection{FEED PREPARATIONS}

Table 1 gives the masses of SRS average salt feed compounds needed to prepare the $140 \mathrm{~L}$ of salt feed for the test. Table 2 gives the masses of the chemical compounds needed to prepare $37 \mathrm{~L}$ of synthetic recycle wash water. This was added to CSTR 1 along with the other feeds to simulate the recycle of wash water from the TPB recovery and recycle process. Some actual TPB recycle wash water from Test 3 had been reserved for use at the beginning of Test 4 . The quantity of synthetic wash water prepared assumed a 90-h run time at $6.86 \mathrm{~mL} / \mathrm{min}$ after the recycle wash water from Test 3 was exhausted. The results of the washing of Test 3 slurry are shown in Table 3. Because of the low recovery of sodium tetraphenylborate (NaTPB) in the slurry wash, extra NaTPB was added directly to the recycle wash-water tank in the cell (to bring the TPB concentration up to $0.033 M$ ) before the test was started. The synthetic recycle water contained enough NaTPB $(0.03303 M)$ to provide $60 \%$ excess of the stoichiometric NaTPB requirement to CSTR 1. To provide a stoichiometric amount of NaTPB to CSTR 1 to precipitate the potassium, $6.52 \mathrm{~L}$ of the NaTPB feed was planned for Test $4(0.68-\mathrm{mL} / \mathrm{min}$ feed rate). The concentrations of NaTPB and $\mathrm{NaOH}$ in this feed solution were 0.5545 and $0.96 M$, respectively. 
Table 1. Average SRS salt feed preparation for Test 4

\begin{tabular}{|c|c|c|c|c|c|}
\hline $\begin{array}{l}\text { Chemical } \\
\text { species }\end{array}$ & $\begin{array}{l}\text { Molarity } \\
(\mathrm{mol} / \mathrm{L})\end{array}$ & Compound & $\begin{array}{c}\text { Molecular } \\
\text { weight } \\
\text { (g/mol) }\end{array}$ & $\begin{array}{c}\text { Mass } \\
(\mathrm{g} / \mathrm{L})\end{array}$ & $\begin{array}{c}\text { Mass }^{a, b} \\
(\mathrm{~g} / 206.4 \mathrm{~L})\end{array}$ \\
\hline $\mathrm{Cs}^{+c}$ & 0.00016 & $\mathrm{CsCl}$ & 168.36 & 0.027 & 5.6 \\
\hline $\mathrm{K}^{+}$ & 0.0171 & $\mathrm{KNO}_{3}$ & 101.1 & 1.729 & 356.9 \\
\hline $\mathrm{OH}^{-}$ & 3.611 & $\mathrm{NaOH}$ & 40.00 & 144.46 & $29,816.5$ \\
\hline $\mathrm{NO}_{3}^{-}$ & $1.388^{d}$ & $\mathrm{NaNO}_{3}$ & 84.99 & 117.97 & $24,349.0$ \\
\hline $\mathrm{NO}_{2}^{-}$ & 0.594 & $\mathrm{NaNO}_{2}$ & 69.00 & 40.98 & $8,458.3$ \\
\hline $\mathrm{AlO}_{2}^{-}$ & 0.354 & $\mathrm{Al}\left(\mathrm{NO}_{3}\right)_{3} \cdot 9 \mathrm{H}_{2} \mathrm{O}$ & 375.14 & 132.80 & $27,409.9$ \\
\hline $\mathrm{CO}_{3}{ }^{2-}$ & 0.183 & $\mathrm{Na}_{2} \mathrm{CO}_{3} \cdot \mathrm{H}_{2} \mathrm{O}$ & 124.01 & 22.69 & $4,683.2$ \\
\hline $\mathrm{SO}_{4}^{2-}$ & 0.171 & $\mathrm{Na}_{2} \mathrm{SO}_{4}$ & 142.04 & 24.29 & $5,013.5$ \\
\hline $\mathrm{Cl}^{-}$ & 0.0286 & $\mathrm{NaCl}$ & 58.4 & 1.671 & 344.8 \\
\hline $\mathrm{F}$ & 0.0366 & $\mathrm{NaF}$ & 41.99 & 1.537 & 317.3 \\
\hline $\mathrm{HPO}_{4}{ }^{2-}$ & 0.0114 & $\mathrm{Na}_{2} \mathrm{HPO}_{4} \cdot 7 \mathrm{H}_{2} \mathrm{O}$ & 268.09 & 3.056 & 630.7 \\
\hline $\mathrm{C}_{2} \mathrm{O}_{4}{ }^{2-}$ & 0.0091 & $\mathrm{Na}_{2} \mathrm{C}_{2} \mathrm{O}_{4}$ & 134.00 & 1.219 & 250.6 \\
\hline $\mathrm{SiO}_{3}^{2-}$ & 0.0046 & $\mathrm{Na}_{2} \mathrm{SiO}_{3} \cdot 9 \mathrm{H}_{2} \mathrm{O}$ & 284.2 & 1.307 & 269.8 \\
\hline $\mathrm{MoO}_{4}{ }^{2-}$ & 0.00023 & $\mathrm{Na}_{2} \mathrm{MoO}_{4} \cdot 2 \mathrm{H}_{2} \mathrm{O}$ & 241.95 & 0.056 & 11.5 \\
\hline $\mathrm{H}_{2} \mathrm{O}$ & & & & 796.0 & 164,290 \\
\hline \multirow[t]{2}{*}{$\mathrm{Na}^{+}$} & 6.42 & & & & \\
\hline & & & Totals & $1,289.8$ & $266,207.6$ \\
\hline
\end{tabular}

${ }^{a}$ Assumes $160-\mathrm{h}$ run time at $21.5 \mathrm{~mL}$ (salt feed)/min, or 1.29-L/h salt feed; also accounts for salt feed added to CSTRs and Slurry Concentrating Tank at beginning of test.

${ }^{b}$ Calculated density for preparation $=(180,567 \mathrm{~g}) /(140,000 \mathrm{~mL})=1.29 \mathrm{~g} / \mathrm{mL}$.

${ }^{c} 5.53 \mathrm{~g}$ of $\mathrm{CsCl}$ in $70 \mathrm{~mL}$ water was mixed well with $1.83 \mathrm{Ci}$ of ${ }^{137} \mathrm{Cs}$ tracer (mass of ${ }^{137} \mathrm{Cs}$ was $0.021 \mathrm{~g}$, but total cesium mass in tracer was $0.085 \mathrm{~g}$ ). The ${ }^{137} \mathrm{Cs}$ concentration in the salt feed was $8.9 \mathrm{mCi} / \mathrm{L}$.

${ }^{d}$ The target molarity for $\mathrm{NO}_{3}{ }^{-}$is $2.45 \mathrm{~mol} / \mathrm{L}$. The addition of $\mathrm{Al}\left(\mathrm{NO}_{3}\right)_{3} \cdot 9 \mathrm{H}_{2} \mathrm{O}$ provides $1.062 \mathrm{~mol} \mathrm{NO}_{3}{ }^{-} / \mathrm{L}$ $\left[2.45-1.068=1.388 \mathrm{~mol}\left(\mathrm{NaNO}_{3}\right) / \mathrm{L}\right.$ extra needed $]$. 
Table 2. Simulated recycle solution preparation for Test 4

\begin{tabular}{|c|c|c|c|c|c|}
\hline $\begin{array}{l}\text { Chemical } \\
\text { species }\end{array}$ & $\begin{array}{l}\text { Molarity } \\
(\mathrm{mol} / \mathrm{L})\end{array}$ & Compound & $\begin{array}{c}\text { Molecular } \\
\text { weight } \\
(\mathrm{g} / \mathrm{mol}) \\
\end{array}$ & $\begin{array}{l}\text { Mass } \\
(\mathrm{g} / \mathrm{L})\end{array}$ & $\begin{array}{c}\text { Mass }^{a, b} \\
\text { (g/37 L) }\end{array}$ \\
\hline $\mathrm{TPB}^{-}$ & 0.03303 & $\mathrm{NaTPB}$ & 342.23 & 11.30 & 418.10 \\
\hline $\mathrm{OH}^{-}$ & 0.6584 & $\mathrm{NaOH}$ & 40.00 & 26.346 & 974.80 \\
\hline $\mathrm{NO}_{3}^{-}$ & 0.2531 & $\mathrm{NaNO}_{3}$ & 84.99 & 21.511 & 795.91 \\
\hline $\mathrm{NO}_{2}^{-}$ & 0.1083 & $\mathrm{NaNO}_{2}$ & 69.00 & 7.473 & 276.50 \\
\hline $\mathrm{AlO}_{2}^{-}$ & 0.0645 & $\mathrm{Al}\left(\mathrm{NO}_{3}\right)_{3} \cdot 9 \mathrm{H}_{2} \mathrm{O}$ & 375.14 & 24.196 & 895.25 \\
\hline $\mathrm{CO}_{3}^{2-}$ & 0.0334 & $\mathrm{Na}_{2} \mathrm{CO}_{3} \cdot \mathrm{H}_{2} \mathrm{O}$ & 124.01 & 4.142 & 153.25 \\
\hline $\mathrm{SO}_{4}^{2-}$ & 0.0312 & $\mathrm{Na}_{2} \mathrm{SO}_{4}$ & 142.04 & 4.432 & 163.98 \\
\hline $\mathrm{Cl}^{-}$ & 0.0052 & $\mathrm{NaCl}$ & 58.4 & 0.304 & 11.24 \\
\hline $\mathrm{F}$ & 0.0067 & $\mathrm{NaF}$ & 41.99 & 0.281 & 10.40 \\
\hline $\mathrm{HPO}_{4}{ }^{2-}$ & 0.0015 & $\mathrm{Na}_{2} \mathrm{HPO}_{4} \cdot 7 \mathrm{H}_{2} \mathrm{O}$ & 268.09 & 0.402 & 14.87 \\
\hline $\mathrm{C}_{2} \mathrm{O}_{4}^{2-}$ & 0.0017 & $\mathrm{Na}_{2} \mathrm{C}_{2} \mathrm{O}_{4}$ & 134.00 & 0.228 & 8.44 \\
\hline $\mathrm{SiO}_{3}{ }^{2-}$ & 0.0008 & $\mathrm{Na}_{2} \mathrm{SiO}_{3} \cdot 9 \mathrm{H}_{2} \mathrm{O}$ & 284.2 & 0.227 & 8.40 \\
\hline $\mathrm{MoO}_{4}{ }^{2-}$ & 0.00004 & $\mathrm{Na}_{2} \mathrm{MoO}_{4} \cdot 2 \mathrm{H}_{2} \mathrm{O}$ & 241.95 & 0.0097 & 0.36 \\
\hline $\mathrm{Na}^{+}$ & 1.20 & & & & \\
\hline \multirow[t]{2}{*}{$\mathrm{H}_{2} \mathrm{O}$} & & & & 950 & 35,150 \\
\hline & & & Totals & $1,051.12$ & $38,881.50$ \\
\hline
\end{tabular}

${ }^{a}$ Assumes 90 -h run time at $6.86 \mathrm{~mL} / \mathrm{min}$ (or $0.412 \mathrm{~L} / \mathrm{h}$ ).

${ }^{b}$ Calculated density for preparation $=(38,881.5 \mathrm{~g}) /(37,000 \mathrm{~mL})=1.05 \mathrm{~g} / \mathrm{mL}$.

Table 3. Results for Test 3 slurry washing at $15 \mathrm{~mL} / \mathrm{min}$

\begin{tabular}{|c|c|c|c|c|}
\hline $\begin{array}{l}\text { Washing } \\
\text { volume } \\
\text { (L) }\end{array}$ & $\begin{array}{l}\text { Washing time } \\
\text { (h) }\end{array}$ & $\begin{array}{l}\text { Recycle wash water } \\
\text { sample ID }\end{array}$ & $\begin{array}{c}\text { RMAL } \\
\mathrm{NO}_{2}^{-}(\mathrm{mg} / \mathrm{L})\end{array}$ & $\begin{array}{l}\text { RMAL } \\
\text { NaTPB } \\
(\mathrm{mg} / \mathrm{L})\end{array}$ \\
\hline 0 & 0 & 00T3W-1 & 20,800 & 267 \\
\hline 3.6 & 4 & 04T3W-2 & 14,400 & 510 \\
\hline 7.2 & 8 & $08 \mathrm{~T} 3 \mathrm{~W}-3$ & 9,130 & 850 \\
\hline 10.8 & 12 & $12 \mathrm{~T} 3 \mathrm{~W}-4$ & 6,470 & 1,300 \\
\hline 14.4 & 16 & $16 \mathrm{~T} 3 \mathrm{~W}-5$ & 3,630 & 1,140 \\
\hline 18 & 20 & $20 \mathrm{~T} 3 \mathrm{~W}-6$ & 1,800 & 1,120 \\
\hline 21.6 & 24 & 24T3W-7 & 1,440 & 948 \\
\hline 25.2 & 28 & $28 \mathrm{~T} 3 \mathrm{~W}-8$ & 971 & 1,440 \\
\hline 28.8 & 32 & $32 \mathrm{~T} 3 \mathrm{~W}-9$ & 721 & 1,260 \\
\hline \multicolumn{2}{|c|}{ Overall tank sample } & $36 \mathrm{~T} 3 \mathrm{~W}-10$ & 5,740 & 1,120 \\
\hline
\end{tabular}


A total of $1237.2 \mathrm{~g}$ NaTPB $[(0.5545 \mathrm{~mol} / \mathrm{L}) \times(6.52 \mathrm{~L}) \times(342.23 \mathrm{~g} / \mathrm{mol})]$ and $25.05 \mathrm{~g} \mathrm{NaOH}$ $[(0.096 \mathrm{~mol} / \mathrm{L}) \times(6.52 \mathrm{~L}) \times(40 \mathrm{~g} / \mathrm{mol})]$ were needed for the preparation. The concentration of MST in the slurry solution in CSTR 1 was set at about $0.5 \mathrm{~g} / \mathrm{L}$. The procedure for the MST stock solution preparation is given in CERS/SR/TPB/005. ${ }^{4}$

Test 4 was scheduled to run about $130 \mathrm{~h}$, which provided for about 18 CSTR volume turnovers. The two CSTRs were left inventoried with process fluids from Test 3. Foam suppressant (IITB52) was added at a rate to provide concentrations of $50 \mathrm{ppm}$ in the CSTRs and $100 \mathrm{ppm}$ in the Slurry Concentrating Tank during Test 4. The various feed materials and feed rates for Test 4 are shown below:

\begin{tabular}{|c|c|c|c|}
\hline \multirow{3}{*}{ Feed materials } & \multicolumn{3}{|c|}{ Feed rates } \\
\hline & \multicolumn{2}{|c|}{ Planned } & \multirow{2}{*}{$\begin{array}{c}\text { Actual } \\
(\mathrm{mL} / \mathrm{min})\end{array}$} \\
\hline & $(\mathrm{mL} / \mathrm{min})$ & $(\mathrm{mL} / \mathrm{h})$ & \\
\hline Salt feed & 21.5 & 1,209 & 21.64 \\
\hline Recycle wash water with excess NaTPB & 6.86 & 411.6 & 6.95 \\
\hline $\begin{array}{r}\text { MST + water (including MST, mercury, } \\
\text { and palladium catalysts) }\end{array}$ & 2.14 & 128.4 & 2.65 \\
\hline NaTPB (including 1PB and benzene) & 0.68 & 40.8 & 0.73 \\
\hline IITB52 feed to CSTR 1 and CSTR 2 & 0.00156 & 0.0935 & 0.00156 \\
\hline IITB52 feed to Slurry Concentrating Tank & 0.00312 & 0.1871 & 0.00312 \\
\hline Total feed rate & 31.19 & & 31.97 \\
\hline
\end{tabular}

\begin{tabular}{|c|c|c|c|}
\hline \multirow[b]{3}{*}{ Catalyst feed } & \multicolumn{3}{|c|}{ Feed rates } \\
\hline & \multicolumn{2}{|c|}{ Planned } & Actual \\
\hline & $(\mathrm{mg} / \mathrm{L})$ & $(\mathrm{mg} / \mathrm{h})$ & $(\mathrm{mg} / \mathrm{h})$ \\
\hline Mercury & 85 & 159 & 136 \\
\hline Palladium & 7.8 & 14.6 & $12.3 / 8.9^{a}$ \\
\hline MST & 500 & 935.7 & 1123 \\
\hline $1 \mathrm{~PB}$ & 500 & 935.7 & 1005 \\
\hline Benzene & 720 & $1,347.4$ & \\
\hline
\end{tabular}

${ }^{a}$ First half of test/second half of test. 


\section{MEASUREMENTS AND SAMPLING}

\subsection{SAMPLING PLANS AND METHODS}

During the tests, samples were taken for analysis according to the sampling plan outlined in CERS/SR/TPB/006, Sampling Plan and Procedure (CSTR Test 4). ${ }^{5}$ After preparation, the salt feed solution was analyzed for potassium, ${ }^{137} \mathrm{Cs}$, and ${ }^{85} \mathrm{Sr}$. During Test 4, effluent samples were taken for each CSTR (sample ports 1 and 2) and a filtrate sample was taken from the Slurry Concentrating Tank filtration system (sample port 4) every $4 \mathrm{~h}$ (a total of 95 samples of 55-65 mL each, collected over a 2-min duration). Each sample was analyzed using an on-site gamma counter for ${ }^{137} \mathrm{Cs}$ and ${ }^{85} \mathrm{Sr}$. Every other sample (8-h time increment) was analyzed by the ORNL Radioactive Materials Analysis Laboratory (RMAL) for ${ }^{137} \mathrm{Cs},{ }^{85} \mathrm{Sr},{ }^{235} \mathrm{U}$, potassium, boron, NaTPB, and TPB decomposition products. Other samples were archived in case additional data were needed.

Samples from ports 1 and 2 were prepared for analysis by filtering the whole sample with either a $0.45-\mu \mathrm{m}$ single filter or a $0.80 / 0.22-\mu \mathrm{m}$ double filter and placing filtrate in new sample bottles for transfer to the RMAL. (A double filter worked best for some of the samples because of the prefilter design of the syringe filter.) Reverse-phase high-performance liquid chromatography (HPLC) was used for NaTPB $( \pm 20 \%)$, triphenylborane (3PB, $( \pm 20 \%)$ ), diphenylborinic acid $(2 \mathrm{~PB},( \pm 20 \%))$, phenylboronic acid $(1 \mathrm{~PB},( \pm 20 \%))$, and phenol $( \pm 20 \%)$. Gamma counting was used for cesium $\left[{ }^{137} \mathrm{Cs}( \pm 10 \%)\right]$ and strontium $\left[{ }^{85} \mathrm{Sr}( \pm 10 \%)\right]$. Inductively coupled plasma-atomic emission spectroscopy (ICP-AES) was used for potassium $( \pm 10 \%)$ and boron $( \pm 10 \%)$ analyses. The potassium and boron samples were digested in nitric acid in a microwave oven prior to analyses. The filtrate samples from the Slurry Concentrating Tank (sample port 4) were sent as-collected to RMAL for analysis after a small sample (1-3 mL) was placed in a counting tube for on-site ${ }^{137} \mathrm{Cs}$ and ${ }^{85} \mathrm{Sr}$ counting, which had an error margin of $\pm 10 \%$ and minimum detectable levels of $3 \mathrm{E}-5 \mu \mathrm{Ci} / \mathrm{g}$ for both ${ }^{85} \mathrm{Sr}$ and ${ }^{137} \mathrm{Cs}$. All samples destined for the RMAL were placed in a refrigerator after preparation, until they could be transported. A chain-of-custody procedure in accordance with the Sample Management Office was followed for all samples sent to RMAL.

The ${ }^{85} \mathrm{Sr}$ in the Test 4 feed resulted from the small amount of simulant intentionally left in the feed tank from Test 3. Almost one-half of the ${ }^{85} \mathrm{Sr}$ had decayed since Test 3, and the Test 3 simulant left in the feed tanks was diluted with new feed by a ratio of about 8 to 1 .

\subsection{MEASURING AND TEST EQUIPMENT}

Electronic balances, which are calibrated annually by ORNL Plant and Equipment Division (P\&E) personnel, were used for solid and liquid mass measurements in preparing the simulants. Class A volumetric flasks and graduated cylinders were used for simulant preparation. To monitor levels of ${ }^{137} \mathrm{Cs}$ and ${ }^{85} \mathrm{Sr}$ during the CSTR tests, a gamma-counting system consisting of an ORTEC model GMX-45220-P-S intrinsic germanium detector, an ORTEC model 672 counting system amplifier, a Canberra Accuspec-A MCA card, and Canberra Genie-2000 spectroscopy software were used.

Instrumentation used in the CSTR system was calibrated before startup. Calibration records are maintained in registered logbooks and in a controlled project file. A revised list of instruments and corresponding calibration schedules was generated after the modifications to the CSTR system had been reviewed and approved by SRS and Oak Ridge investigators (CERS/SRS/TPB/009, 8/04/2000). 


\section{RESULTS OF TEST 4}

\subsection{RUN SUMMARY}

Test 4 was successfully conducted October 9-15, 2000. The actual run time (time in which the feeds were being pumped to CSTR 1) was $125.5 \mathrm{~h}$. About $18 \mathrm{~h}$ after starting the test, the run was put on hold for $5 \mathrm{~h}$ to replace the CSTR 1 sample valve, which had plugged and allowed the level in CSTR 1 to rise almost to the overflow level. Two batches of concentrated slurry (about $10 \mathrm{wt} \%$ insoluble TPB and MST reaction products) were produced and then washed to evaluate the recovery of TPB after the test was completed. The temperature of the slurries in the system vessels was maintained at $25^{\circ} \mathrm{C}$ for the first $76 \mathrm{~h}$ of operation, producing the first batch of $10 \mathrm{wt} \%$ concentrated slurry. The temperature was then ramped to $45^{\circ} \mathrm{C}$ over the next $13 \mathrm{~h}$. During this period, the temperature in each vessel was increased in $5^{\circ} \mathrm{C}$ steps and held for about $3 \mathrm{~h}$ at each step. The temperature was maintained at $45^{\circ} \mathrm{C}$ for $43 \mathrm{~h}$ to produce the second batch of $10 \mathrm{wt} \%$ concentrated slurry. Benzene was not added to the system during the testing at elevated temperature.

The test plan (CERS/SR/TPB/010, Rev. 0) ${ }^{6}$ called for initial operation at $25^{\circ} \mathrm{C}$ for the production of the first batch of concentrated TPB/MST slurry. The two CSTRs were full of slurry that was left in these vessels at the completion of Test 3 , with the intent of maintaining the required cesium DF from the beginning to the end of the test. To prevent settling of the solids from Test 3 , the agitators in both CSTRs were operated at 500-600 rpm for the 2-month period between Test 3 and Test 4 startup. The vessel agitators were then operated at $650-850 \mathrm{rpm}$ throughout Test 4 . Although the test plan called for operation at up to $1200 \mathrm{rpm}$, the speeds were not increased after the first valve plug incident in an attempt to prevent any solids from plugging the slurry transport lines connecting the CSTRs and the Slurry Concentrating Tank. Antifoam (IITB52) was pumped to each of the vessels during the test. The test plan called for the MST/water feed supply containing the catalyst to provide concentrations of about $7.8 \mathrm{mg}$ of palladium and $85 \mathrm{mg}$ of mercury per liter of slurry in CSTR 1. A solution of 1PB was added to the NaTPB feed stream and provided about $500 \mathrm{mg}$ of 1PB per liter of slurry in CSTR 1. Benzene was added to the TPB feed stream (via a syringe pump that was connected to the feed line) at a rate that provided a benzene concentration in the CSTR 1 slurry of about $720 \mathrm{mg} / \mathrm{L}$. The benzene addition began $23 \mathrm{~h}$ after the test started and was discontinued prior to increasing the process temperature to $45^{\circ} \mathrm{C}$. Benzene production was monitored in each of the process vessels by on-line FTIR analyses of the nitrogen purge gas for the vessels.

The process control of the slurry concentration system for Test 4 was excellent. The cross-flow filter backpulsing system worked well and was very effective at 25 and $45^{\circ} \mathrm{C}$. No backpulse was needed after an initial one near the end of the temperature ramping period. No foam problems occurred in either the CSTR or in the Slurry Concentrating Tank. The benzene analysis system generally worked well and allowed the benzene in the vessel vapor spaces to be continually monitored during all parts of the test. The slurry wash cross-flow filter also worked well, and no problems occurred during the slurry washes.

Overall, more than $161 \mathrm{~L}$ of radioactive simulated feed was treated. Two 6-7 L batches of $10 \mathrm{wt} \%$ concentrated slurry were collected and subsequently washed. More than $230 \mathrm{~L}$ of filtrate was collected from the Slurry Concentrating Tank cross-flow filter. Each batch of concentrate was washed for $24 \mathrm{~h}$, and the separated wash water $(\sim 28 \mathrm{~L})$ was collected and saved for use as startup recycle water in Test 5. The planned and actual flow summaries are shown in Table 4. Afterward, both cross-flow filter systems were chemically cleaned with $2 \%$ oxalic acid solution, rinsed well with water, and then rinsed and stored in $1 M \mathrm{NaOH}$. 
The overall system operation and the behavior of the components of the system met test plan specifications and objectives. The most difficult operational problems in Test 4 occurred with the MST/catalyst/dilution water delivery system. One was maintaining the MST and catalyst particles in a uniform suspension in the feed tank. The mixture of MST, mercury, and palladium (5\%) on gamma alumina proved significantly more dense and "sticky" (i.e., it agglomerated to form stringy particle masses that settled quickly) than the MST/water-only slurry had been in previous tests. The other problem occurred in the transfer tubing, which often plugged when solids settled at wide places in the line or in the check valve in the line inside the hot cell. Finally, a plug in the check valve could not be cleared and flow was lost for 3-4 h (between the hours 98 and 104 of the test). To continue MST/catalyst/dilution water flow to CSTR 1, a plumbing connection was made with the TPB line at a tee next to the cell wall so that the MST/catalyst/dilution water could be added with the TPB solution. With time, the check valve for this line even tended to plug; however, pumping continued until the end of the test without further interruptions to either the TPB or the MST/catalyst/water flow.

Table 4. Process performance for Test 4

\begin{tabular}{lcc}
\hline & \multicolumn{2}{c}{ Volume (L) $^{n}$} \\
\cline { 2 - 3 } Salt feed & Planned $^{a}$ & Actual $^{b}$ \\
& 161.9 & $167.6(\sim 4.6$ L leaked out during \\
Recycle wash water & 51.5 & 24.2 actual +28.1 \\
& & synthetic $=52.3$ total \\
Na TPB & 5.1 & 5.5 \\
Water + MST & 16.1 & $20.0^{c}$ \\
Filtrate from cross-flow filter & 218.9 & 218 \\
Slurry produced & 13 & 13 \\
\hline
\end{tabular}

${ }^{a}$ Planned test time was $132 \mathrm{~h}$ for both parts.

${ }^{b}$ Actual test time was $130.3 \mathrm{~h}(125.5 \mathrm{~h}$ actual feeding).

${ }^{c}$ The flow was off for $4 \mathrm{~h}$ (water + MST+ catalyst) when the feed line plugged in the check valve. Flow was rerouted through the TPB feed line.

For Test 5, modifications to the MST/catalyst/dilution water delivery system must be made to mitigate or prevent the reoccurrence of the Test 4 problems. The feed lines will be replaced, and the feed tank/agitator system must be redesigned. In addition, an effort will be made to determine chemical adjustments necessary to prevent agglomeration of the MST/catalyst mixture.

\subsection{DETAILS OF SYSTEM CHEMISTRY}

\subsubsection{Cesium and Strontium Decontamination of Test 4 Feed}

During Test 4, even at elevated temperatures, the ${ }^{137} \mathrm{Cs}$ DFs for the filtrates from the Slurry Concentrating Tank (as measured by ORNL RMAL) were >56,000, with some values as high as 650,000. The decontamination chemistry was excellent; these values exceeded the DF goal of 40,000 (99.998\% removal). Furthermore, DF values for filtrate samples from CSTR 2 were also very high, ranging from 21,000 to 104,000 , with most values $>37,000$. The same was the case for the CSTR 1 filtrate samples, 
which had DFs ranging from 21,000 to 140,000 . A high percentage of the samples had values $>30,000$. The ${ }^{137} \mathrm{Cs}$ DF results are given in Figs. 7-12 and provide a comparison with the on-site counting results. It should be noted that most of the cesium decontamination appeared to be completed in the first CSTR, but this may be an artifact of the sampling. Because at least $15 \mathrm{~min}$ is required between the time the sample is removed from the CSTR and the time that the filtrate and slurry are separated, additional precipitation time for the cesium removal is available. The need for the second CSTR is primarily for the removal of strontium and uranium by MST. The use of the palladium catalyst at $45^{\circ} \mathrm{C}$ did not cause any loss of DF (in any vessel) even with the TPB actively decomposing.

The on-site process control analysis gave consistently higher values for cesium (or lower DFs) than did RMAL analysis. This is partially due to differences in counting geometry, etc. The ${ }^{137} \mathrm{Cs} \mathrm{DFs}$ for the Slurry Concentrating Tank filtrates ranged between 16,000 and 287,000, with most values $>30,000$. During the first part of the test $\left(\right.$ at $25^{\circ} \mathrm{C}$ ), the CSTR 1 on-site and RMAL results are close. However, during the higher-temperature portion of the test, the difference between the two analyses is somewhat greater. Figure 11 shows little difference between the on-site and RMAL cesium removal results for CSTR 2. The on-site cesium DFs were in the 17,000 to 63,000 range, with most values $>25,000$. The sampling results for the Slurry Concentrating Tank filtrates are given in Fig. 12. These show a wider variation between the on-site and RMAL analyses. The differences were smaller when the slurry was being heated during the last $55 \mathrm{~h}$ of the test. The DF values for the Slurry Concentrating Tank filtrates are the most important. They show that the process, even with TPB decomposition occurring, was producing filtrate that greatly exceeded the SRS WAC requirements for saltstone.

The on-site cesium DFs were in the 17,000 to 63,000 range during the time between completion of the first batch of $10 \mathrm{wt} \%$ slurry and the end of the test during operation at $45^{\circ} \mathrm{C}$ (see Fig. 9). Several filtrate samples indicated (by on-site counting) reduced DFs in the range of 3000 to 10,000. Samples of those filtrates that were refiltered at room temperature with $0.2-\mu \mathrm{m}$ syringe filters gave DFs that were higher and in the acceptable range. This indicates that insoluble ${ }^{137} \mathrm{Cs}$ penetrated the cross-flow filter membrane or was precipitated after the cross-flow filtration and cooldown of the samples.

No strontium was added to the salt feed for Test 4 . However, residual ${ }^{85} \mathrm{Sr}$ remained in the heel of the feed left from Test 3, which was designed to measure the strontium removal. The calculated strontium concentration in the Test 4 salt feed was $5.6 \mu \mathrm{g} / \mathrm{L}$, compared with $44.8 \mu \mathrm{g} / \mathrm{L}$ in the Test 3 salt feed. The ${ }^{85} \mathrm{Sr}$ data plotted in Fig. 13 show that the MST effectively removed strontium in Test 4; DFs in the range of 100 to 200 were maintained for the duration of the test (above the DF level of approximately 26 that is anticipated to be required).

Although the palladium catalyst mixture was continuously added to cause TPB decomposition during Test 4, the cesium DFs for CSTR 1 remained in the 21,000 to 140,000 range, as shown in Fig. 10. Furthermore, the cesium DF was not lost during the time between Test 3 and Test 4, as shown by the "time-zero" samples. In addition, cesium removal was not affected by increasing the operating temperature to $45^{\circ} \mathrm{C}$ and operating at that temperature during the last $42 \mathrm{~h}$ of the test. 


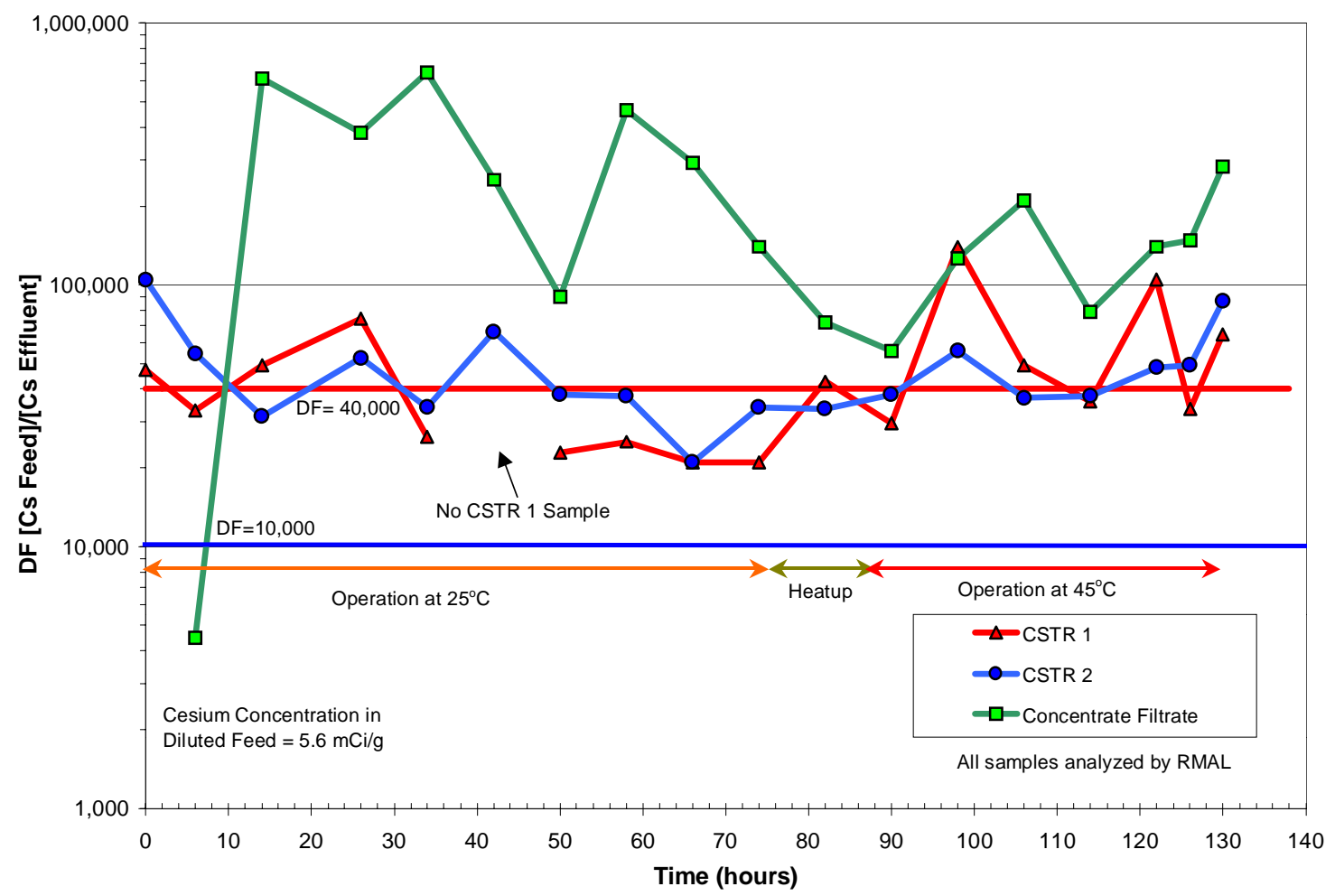

Fig. 7. Test 4 cesium DFs.

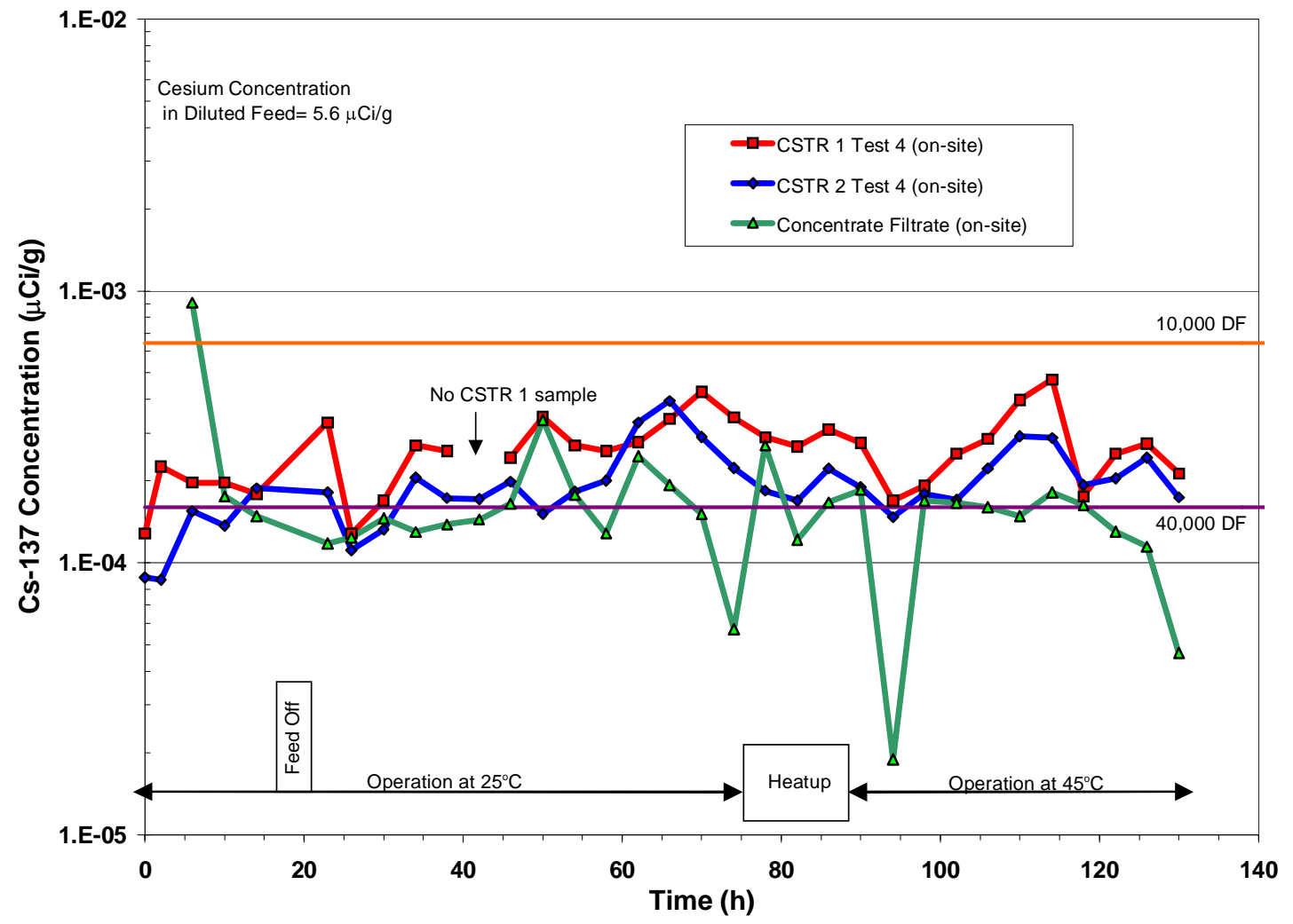

Fig. 8. Cesium concentrations in Test 4. 


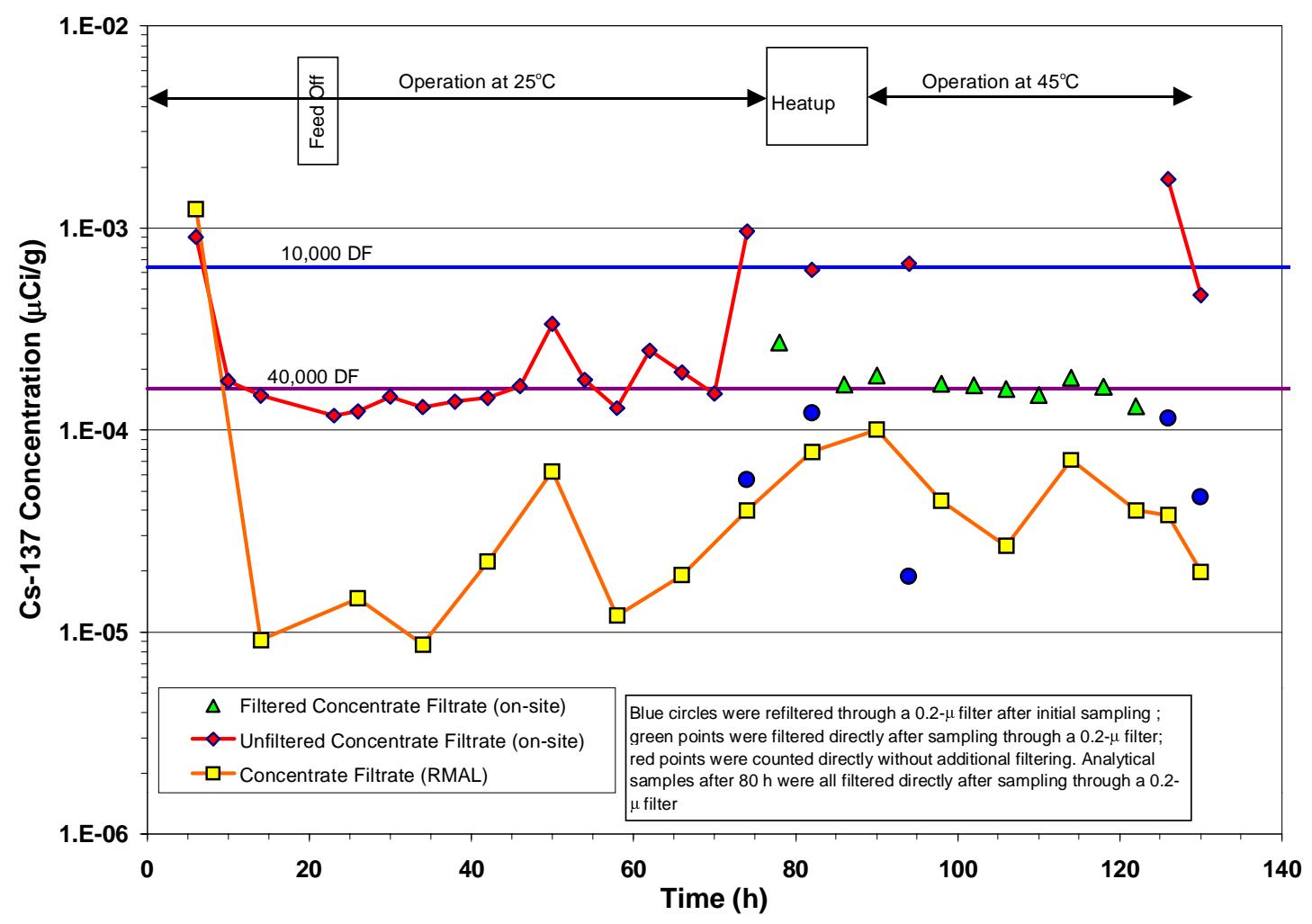

Fig. 9. Cesium concentrations in Test 4 concentrate filtrate showing filtration differences.

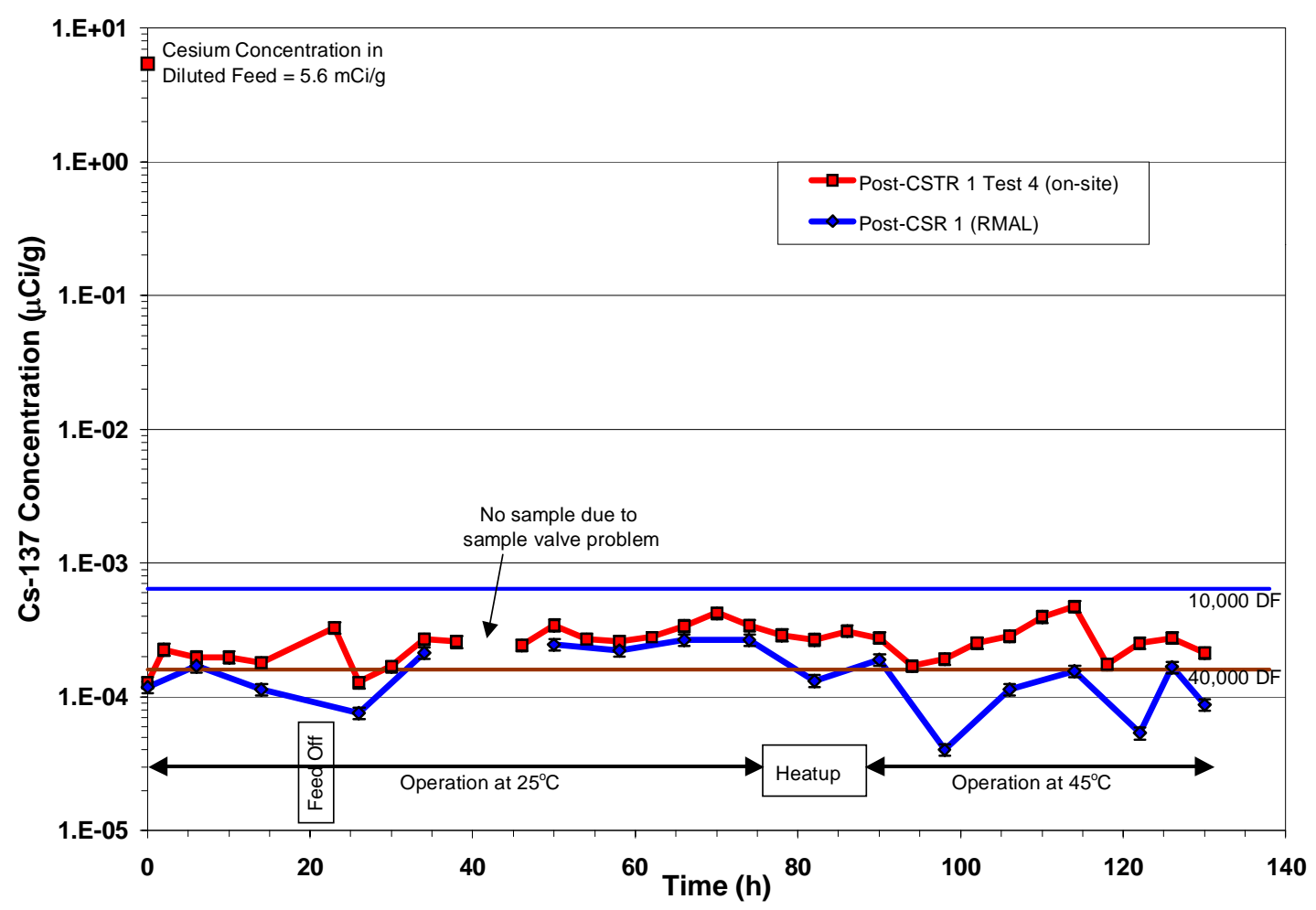

Fig. 10. Cesium concentrations in Test 4, after CSTR 1. 


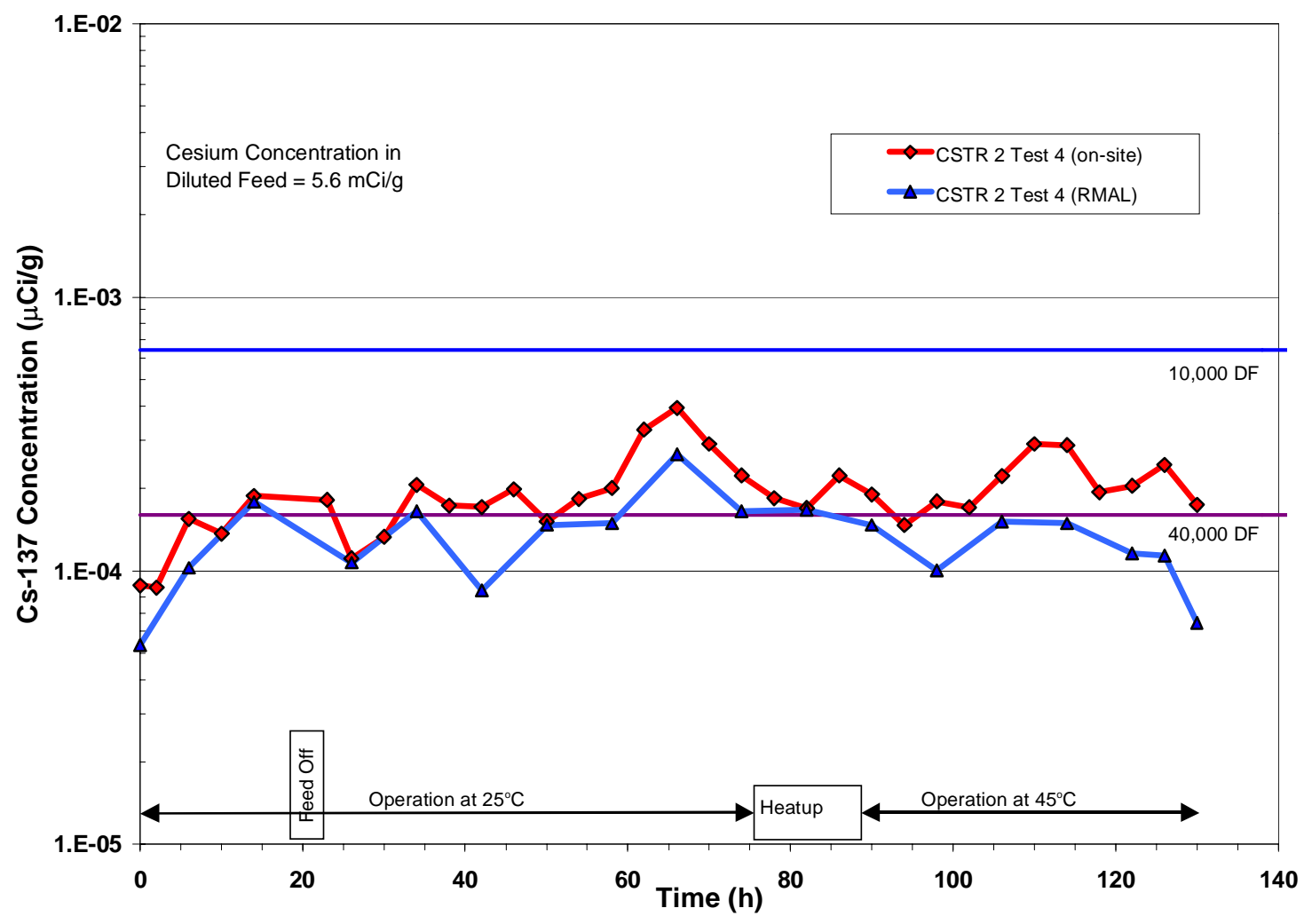

Fig. 11. Cesium concentrations in Test 4, after CSTR 2.

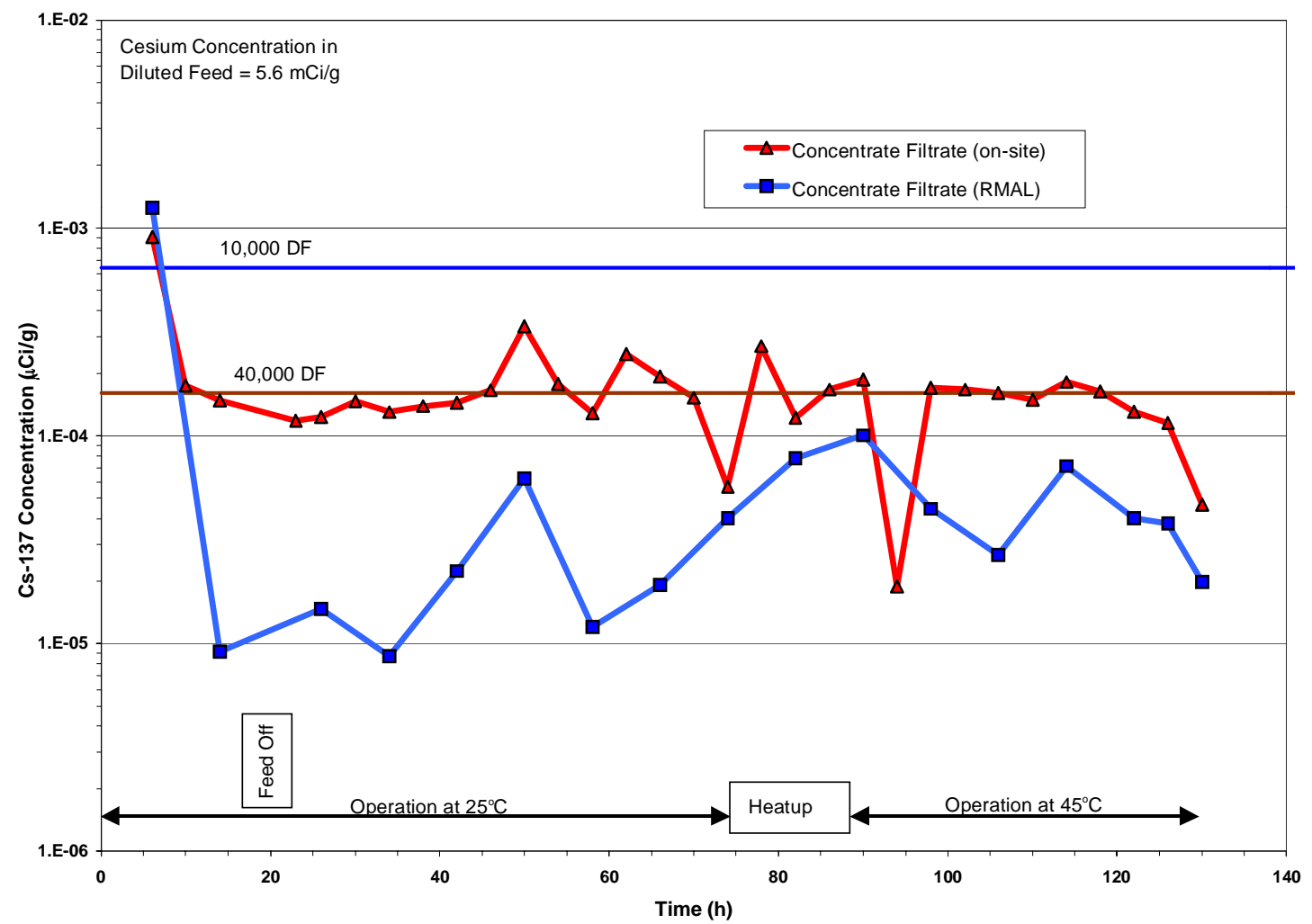

Fig. 12. Cesium concentrations in Test 4, after Slurry Concentrating Tank. 


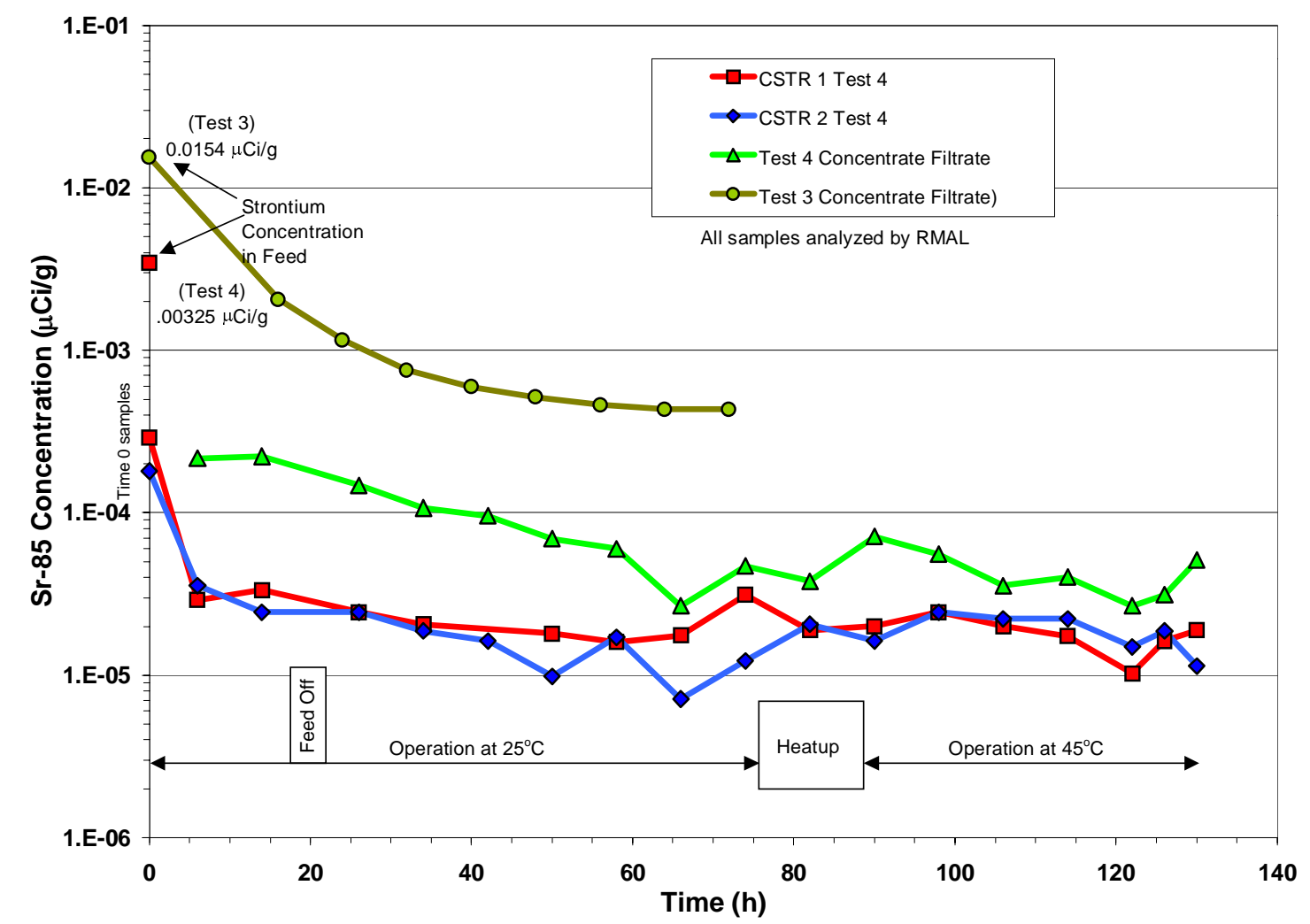

Fig. 13. Analytical concentrations of ${ }^{85} \mathrm{Sr}$ in Test 4 process vessels.

\subsubsection{HPLC Analyses for TPB Decomposition Products}

Figures 14-16 show the results of the HPLC and ICP analyses of samples of filtrates from the two CSTR filtered overflows and the concentrate filtrate. The graphs do not show any results for 2PB, because of difficulties in resolving its peak in the presence of the large amount of 1PB added to the system with the feed. Each figure also shows the benzene concentration of the vessel off-gas, as analyzed by the on-line FTIR analyzers. In Fig. 14, CSTR 1 analyses show the TPB decomposition rates calculated from the benzene in the off-gas during the addition of benzene for the 23- to 68-h time frame and from heating the slurry at $45^{\circ} \mathrm{C}$ in the last $47 \mathrm{~h}$ of the test (with no benzene addition). Benzene was pumped via the NaTPB feed line to CSTR 1 at a rate of $22.46 \mathrm{mg} / \mathrm{min}$, which was calculated to yield a concentration of benzene in the slurry of $720 \mathrm{mg} / \mathrm{L}$. No benzene was detected in the CSTR 1 off-gas until the benzene addition began. The benzene concentration in the off-gas increased during the next $10 \mathrm{~h}$ to about $400 \mathrm{ppm}$ and remained at $398 \pm 35 \mathrm{ppm}$ until the addition of benzene was stopped at $68 \mathrm{~h}$. After this point, the off-gas concentration decreased to about $90 \mathrm{ppm}$ during the next $18 \mathrm{~h}$. The slurry was heated to $45^{\circ} \mathrm{C}$ during the last $12 \mathrm{~h}$ of this time. Even after the process temperature reached $45^{\circ} \mathrm{C}$, the benzene concentration continued to decline to about $60 \mathrm{ppm}$ over the next $12 \mathrm{~h}$. It was found, however, that the catalyst/MST feed line had become plugged for about $3 \mathrm{~h}$ during the $95-$ to 98 -h time period. At $101 \mathrm{~h}$ into the test, the catalyst/MST line was attached to the NaTPB supply line to continue providing MST and catalyst to the CSTR. To overcome the loss of MST and catalyst to the CSTR, the catalyst/MST flow was doubled for about $4 \mathrm{~h}$. At this point in the test, the concentration of benzene, which could be generated only by TPB decomposition, dramatically increased to about $670 \mathrm{ppm}$ at $118 \mathrm{~h}$ and remained at $660 \pm 48 \mathrm{ppm}$ until the end of the test. This increase was likely due to the combined effect of temperature increase and increased catalyst feed rate. 
The concentrations of TPB and TPB decomposition products (also shown in Figs. 17-19) followed reasonable trends in CSTR 1. Phenylboronic acid (1PB), which was pumped (via the NaTPB feed) to CSTR 1 at a rate of $15.6 \mathrm{mg} / \mathrm{min}$, provided the targeted concentration of about $500 \mathrm{mg} / \mathrm{L}$. During the first $14 \mathrm{~h}$ of the test, the concentration of 1PB in the CSTR 1 slurry filtrate, as seen in Fig. 14, increased into the range of 400 to $500 \mathrm{mg} / \mathrm{L}$ The concentration remained in that range with the exception of two short-term dips that may be related to the analytical determinations and possible interferences from other components in the sample matrix. Through the first $78 \mathrm{~h}$ at $25^{\circ} \mathrm{C}$, the concentration of 3PB in CSTR 1 averaged $28 \pm 8 \mathrm{mg} / \mathrm{L}$ (equates to $2.3 \%$ decomposition of the excess NaTPB). After $78 \mathrm{~h}$, the concentration began to increase and continued to climb until the end of the test, reaching $159 \mathrm{mg} / \mathrm{L}$ (equates to $4.2 \%$ decomposition of the total TPB, or about $10 \%$ of the excess TPB). In the decomposition of TPB, 1 mol of benzene is formed for each mole of 3PB formed. The highest 3PB molarity obtained in CSTR 1 was $0.61 \mathrm{~m} M$, which would also have been the concentration of benzene had it remained in liquid form in the slurry. The concentration of soluble TPB averaged $57.8 \pm 24 \mathrm{mg} / \mathrm{L}$ for the test. Its concentration was highest while the slurry was being heated, averaging $77 \pm 17 \mathrm{mg} / \mathrm{L}$. Continuing to maintain TPB in solution guarantees that TPB is available to precipitate any cesium that is present. These data indicate the expected rate of TPB decomposition and the expected increase in decomposition rate when the temperature was increased.

Analyses of the filtered samples from CSTR 2 show somewhat similar results (Fig. 15). The 3PB concentrations were very low during the first $34 \mathrm{~h}$ of the test; all but two of the filtrate samples had values below the detection limit of $15.7 \mathrm{mg} / \mathrm{L}$. From 34 until about $82 \mathrm{~h}$ into the test, the average 3PB concentration was $27 \pm 13 \mathrm{mg} / \mathrm{L}$. This test period also included much of the slurry heat up ramp. Subsequently, the $3 \mathrm{~PB}$ concentration increased steadily to about $140 \mathrm{ppm}$ while the slurry was being heated at $45^{\circ} \mathrm{C}$. Because the 3PB filtrate concentration in CSTR 2 was approximately equal to that in CSTR 1 and because the CSTR 2 slurry represents overflow from CSTR 1, there appears to be little additional decomposition of the TPB in CSTR 2 unless the decomposition rate of 3PB to $2 \mathrm{~PB}$ equals the TPB decomposition rate to $3 \mathrm{~PB}$ (true at steady state). The soluble TPB concentration averaged $39 \pm 16 \mathrm{mg} / \mathrm{L}$. Benzene did not appear in the off-gas of CSTR 2 until after $42 \mathrm{~h}$ of testing. Its concentration steadily increased over the next $28 \mathrm{~h}$ to $200 \mathrm{ppm}$, about the time when the slurry heatup began. During the slurry heatup period, the benzene concentration decreased to about $90 \mathrm{ppm}$. Once at $45^{\circ} \mathrm{C}$ and for the remainder of the test, the benzene concentration steadily increased to about $350 \mathrm{ppm}$. These data show clear evidence of the expected trends of TPB decomposition. 


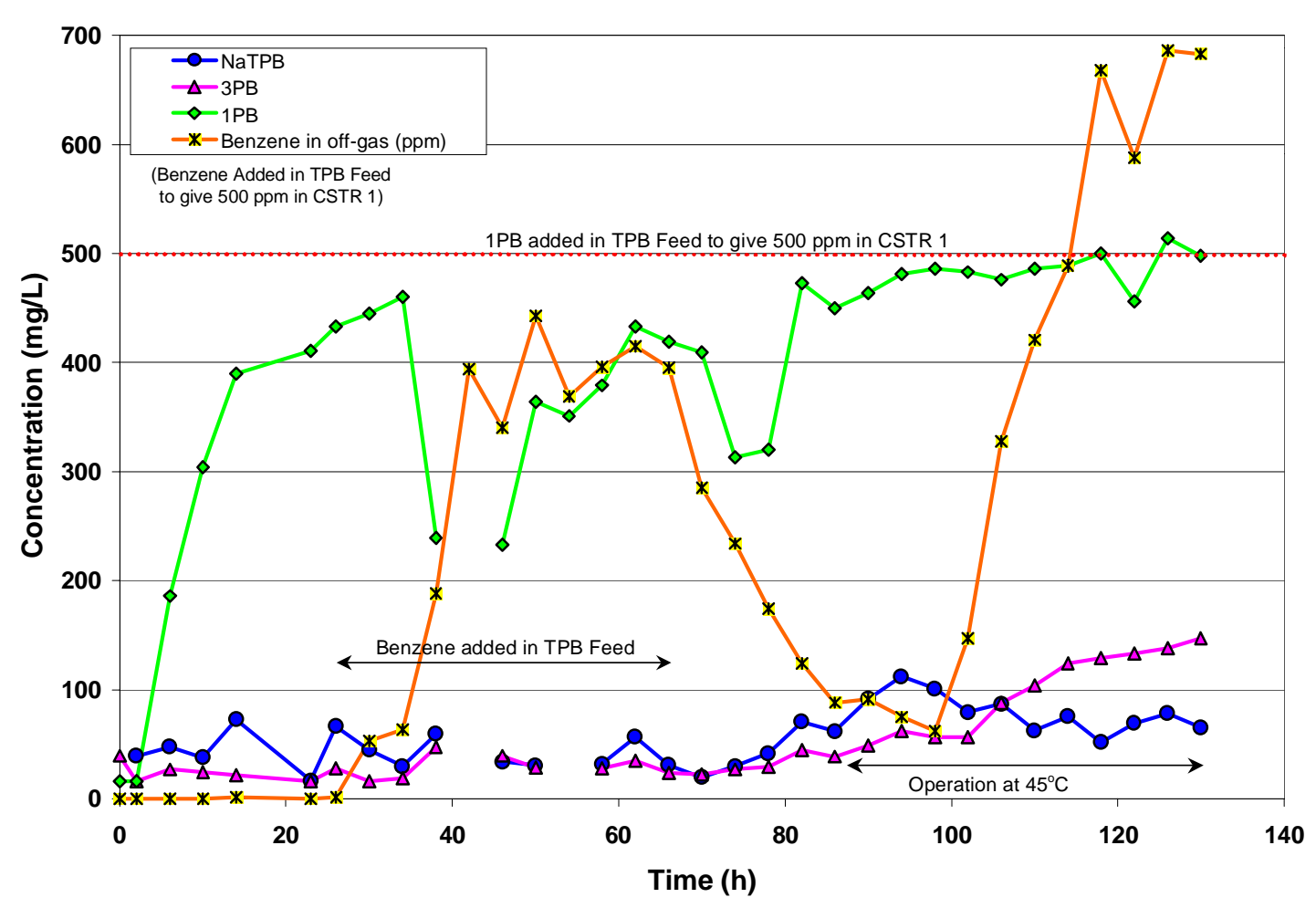

Fig. 14. CSTR 1 HPLC results for Test 4.

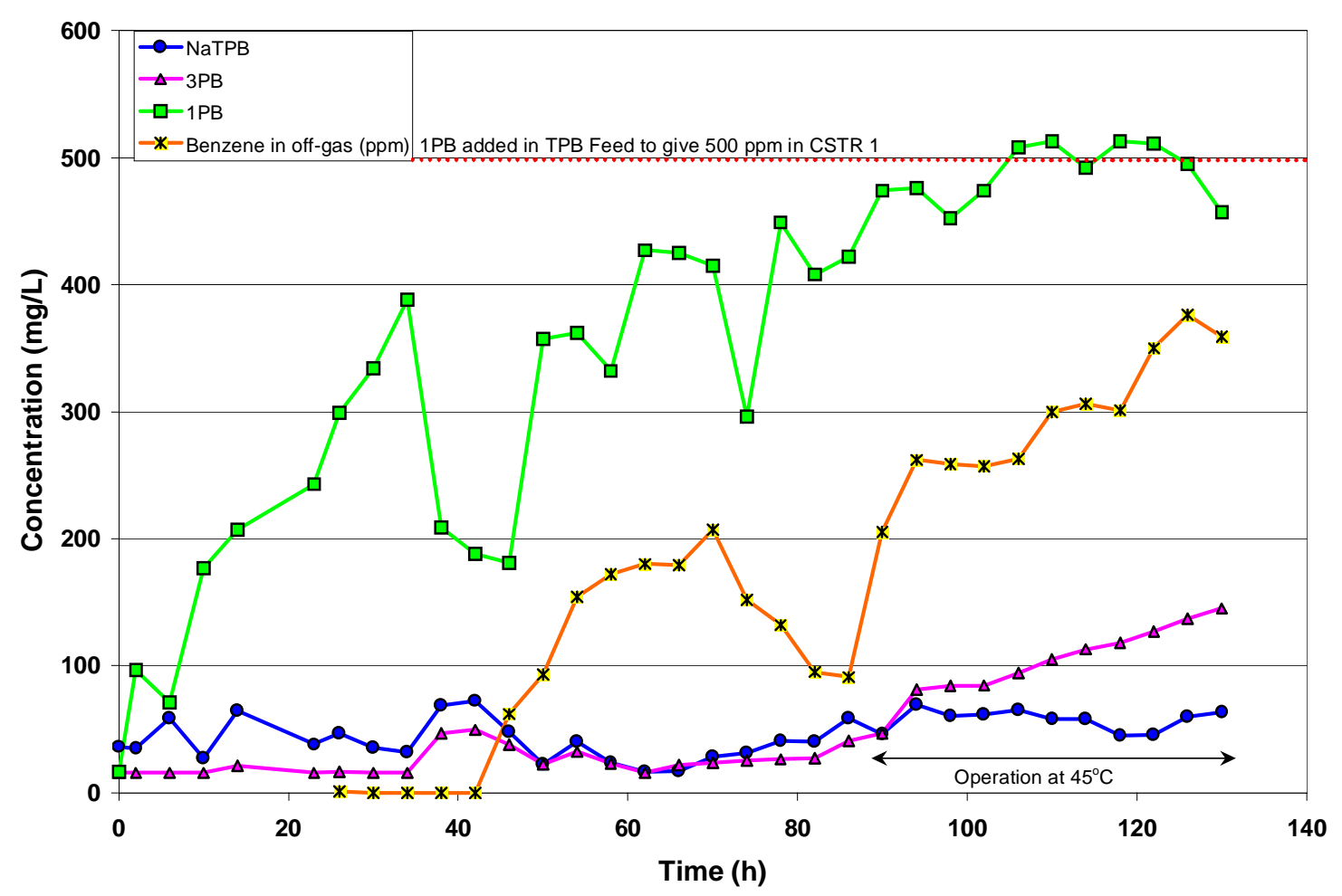

Fig. 15. CSTR 2 HPLC results for Test 4. 


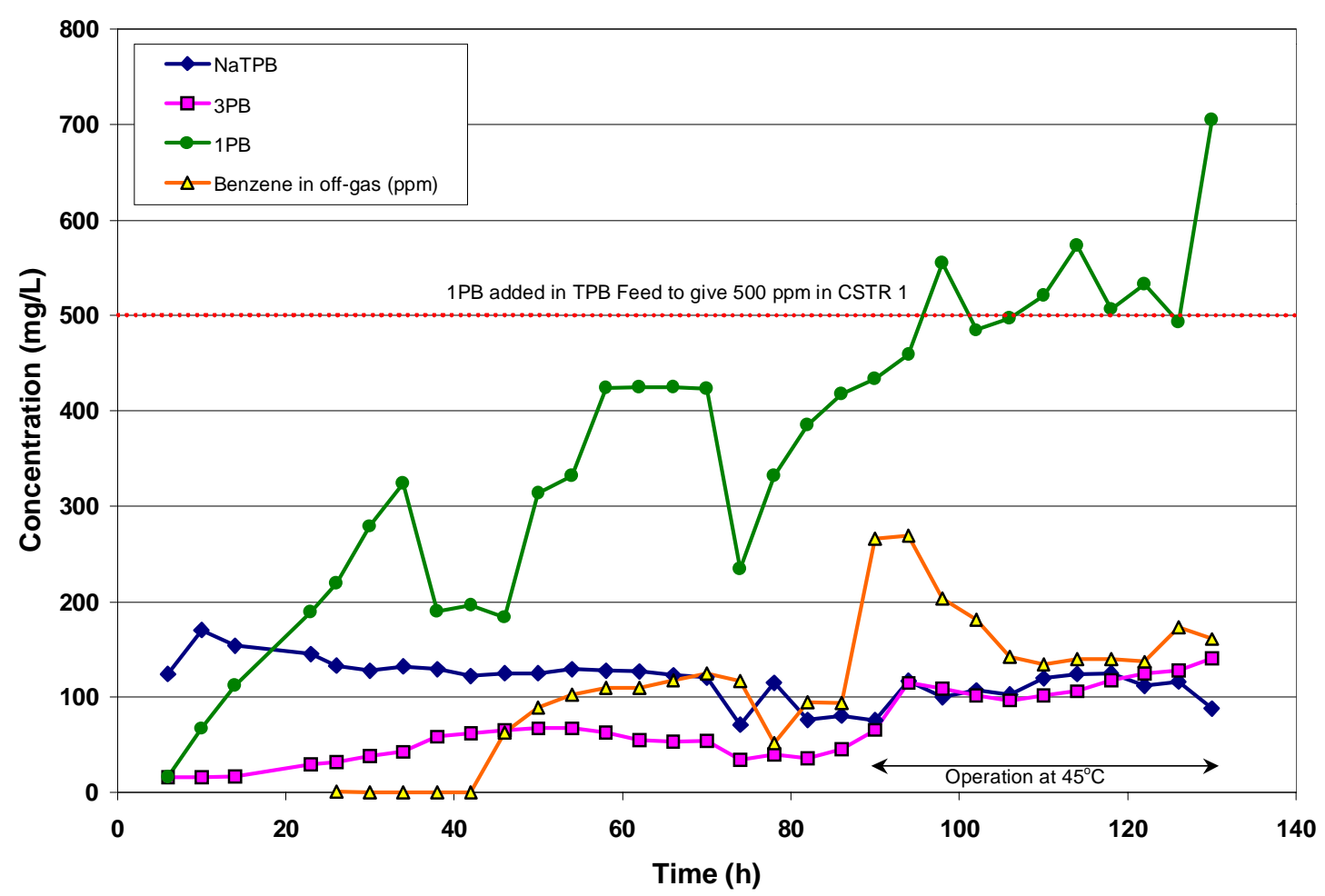

Fig. 16. Slurry Concentrating Tank HPLC results for Test 4.

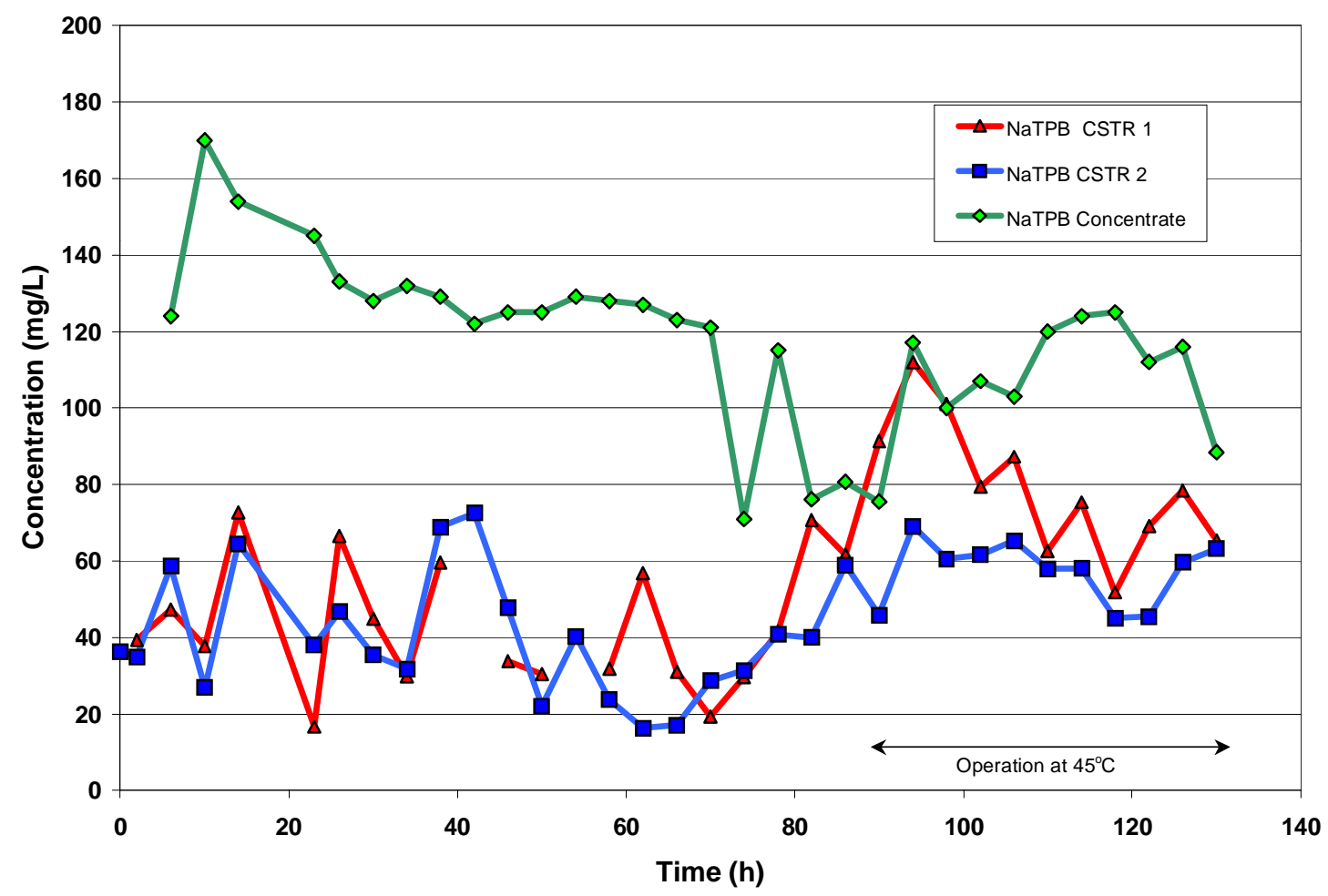

Fig. 17. NaTPB analysis results for Test 4. 


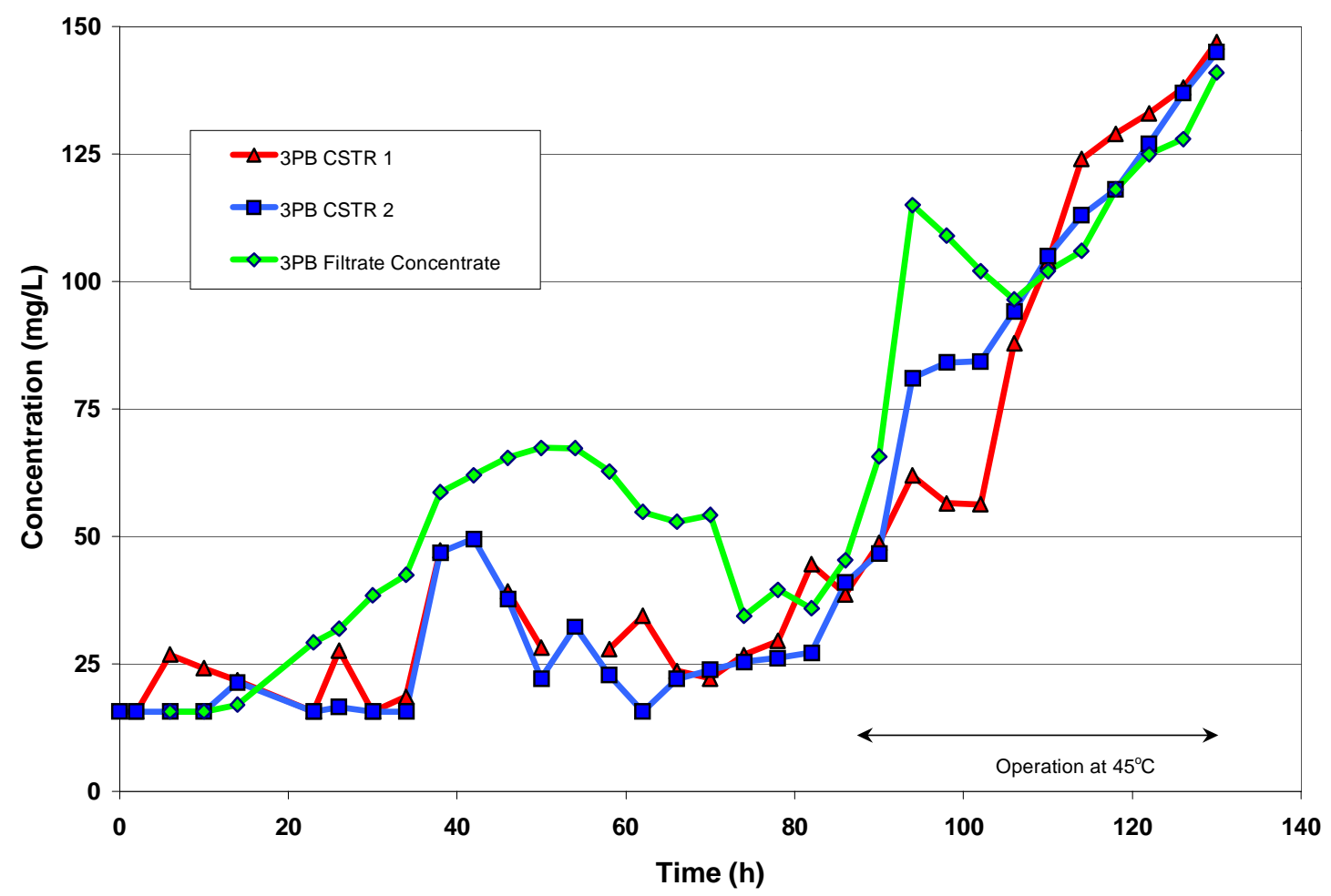

Fig. 18. 3PB analysis results for Test 4.

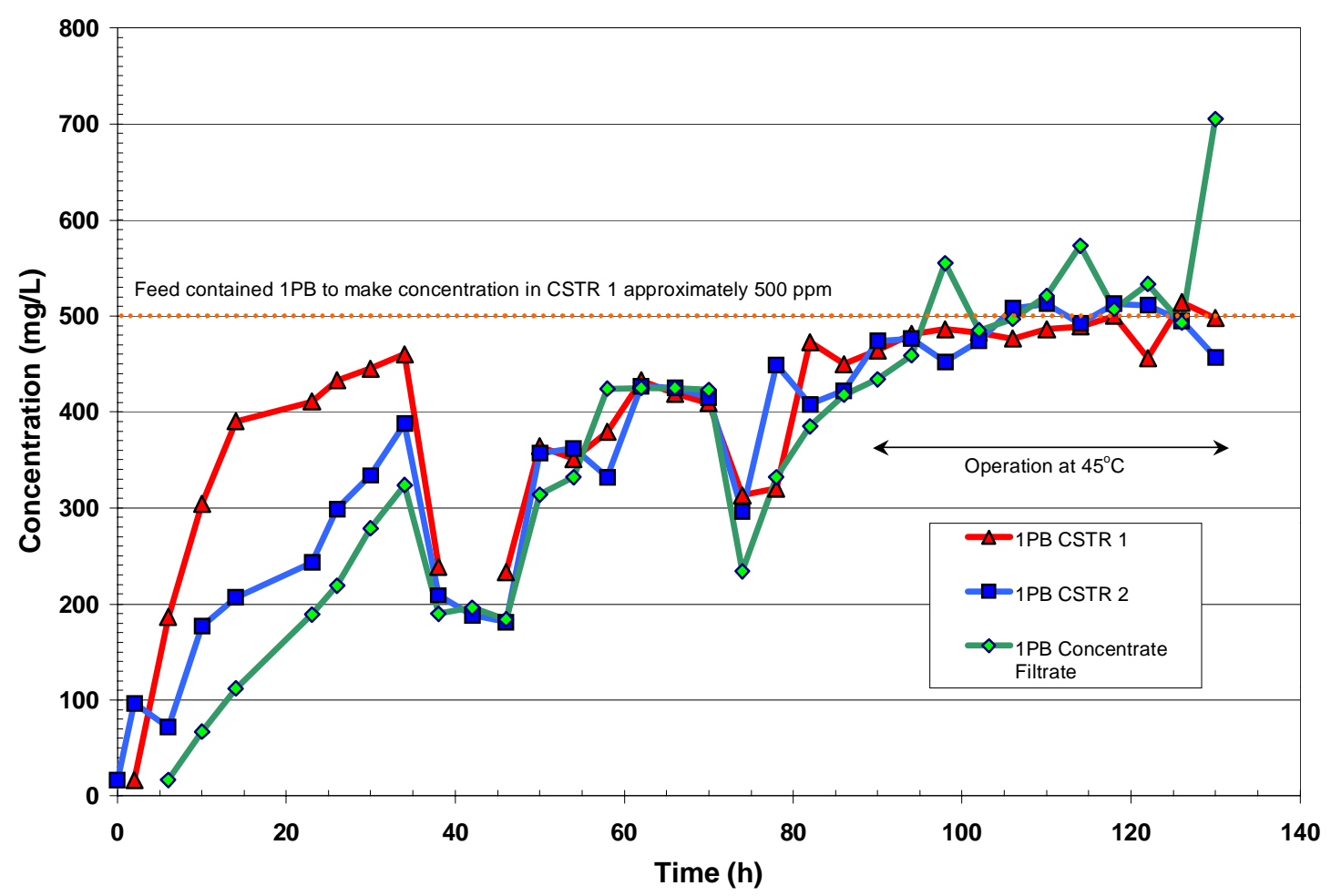

Fig. 19. 1PB analysis results for Test 4 . 
The HPLC results for the Slurry Concentrating Tank filtrate are provided in Fig. 16. During the first half of the test, while the TPB solids were being concentrated to $10 \mathrm{wt} \%$, the concentration of soluble TPB averaged $132 \pm 16 \mathrm{mg} / \mathrm{L}$. After these solids were transferred to the Wash System, the concentration decreased to as low as $71 \mathrm{mg} / \mathrm{L}$. While the second batch of slurry was being concentrated, the TPB concentration increased to an average of $114 \pm 9 \mathrm{mg} / \mathrm{L}$ for the last $40 \mathrm{~h}$ of the test while operating at $45^{\circ} \mathrm{C}$. The $3 \mathrm{~PB}$ levels were below the detection limit during the first $10 \mathrm{~h}$ of the test but averaged $50 \pm 16 \mathrm{mg} / \mathrm{L}$ until the concentrated solids were pumped to the Wash System at $64 \mathrm{~h}$ into the test. During concentration of the second batch of slurry at $45^{\circ} \mathrm{C}$, the $3 \mathrm{~PB}$ concentration increased from a low of $20 \mathrm{mg} / \mathrm{L}$ to a high of $140 \mathrm{mg} / \mathrm{L}$ at the end of the test. The $2 \mathrm{~PB}$ concentrations were below the detection limits. The concentration of $1 \mathrm{~PB}$ increased to about $300-350 \mathrm{mg} / \mathrm{L}$ during the first $40 \mathrm{~h}$ of operation, decreased after slurry transfer, and then increased to a range of 500 to $600 \mathrm{mg} / \mathrm{L}$ during the last $32 \mathrm{~h}$ of the test at $45^{\circ} \mathrm{C}$. No benzene was detected in the Slurry Concentrating Tank off-gas during the first $42 \mathrm{~h}$ of the test. Its concentration then increased to $100 \mathrm{ppm}$ during the next $14 \mathrm{~h}$ and remained between 100 and $120 \mathrm{ppm}$ until the temperature of the slurry reached $45^{\circ} \mathrm{C}$ at the 86th hour of the test. The benzene concentration increased rapidly after $86 \mathrm{~h}$ to $270 \mathrm{ppm}$ for about $8 \mathrm{~h}$, then slowly decreased to about $140 \mathrm{ppm}$ at the 106th hour and remained between 140 and $170 \mathrm{ppm}$ for the remainder of the test. Once again, the trends of TPB and TPB decomposition products indicate the expected rate of decomposition and the increasing trend in the decomposition rate as temperature is increased.

\subsubsection{ICP-AES Analyses for Potassium and Boron}

Figures 20-23 show the ICP-AES results for potassium and boron for the filtered samples from CSTR 1, CSTR 2, and the filtrate from the slurry concentration filter. The potassium for all three vessels started out at lower levels $(100-120 \mathrm{mg} / \mathrm{L}$ ) than those measured at the end of Test 3 (about $200 \mathrm{mg} / \mathrm{L}$ ). This indicates continued precipitation of potassium through reaction with any excess TPB that may have been present. Throughout the course of the test, potassium concentrations in all three vessels gradually decreased to approximately $50-60 \mathrm{mg} / \mathrm{L}$ by the end. Figures $20-23$ also show the boron concentrations and the calculated boron concentrations (equates to the soluble TPB, 3PB, and 1PB and is indicated as PBs in the figures). As shown in Fig. 20, the boron concentration in CSTR 1 increased during the first $30 \mathrm{~h}$ of operation, was fairly constant at about $40 \mathrm{mg} / \mathrm{L}$ during the next $40 \mathrm{~h}$, and then slowly increased to about $53 \mathrm{mg} / \mathrm{L}$ while the temperature was increased to and maintained at $45^{\circ} \mathrm{C}$. The figures illustrate almost no difference between the concentrations of boron measured and those calculated based on the amounts of soluble TPB, 3PB and 1PB present in any of the vessels. The concentration of boron in Test 4 should be about $5 \mathrm{ppm}$ based on the 1PB added with the feed and an additional 2-3 ppm for the 3PB created by decomposition. Since no copper was present to rapidly catalyze the conversion of $1 \mathrm{~PB}$ to benzene, very little boric acid would be expected.

\subsubsection{Benzene Production Rate as a Measure of TPB Decomposition}

An assessment of the TPB decomposition rate was made based on the concentrations of 3PB and $2 \mathrm{~PB}$ in the filtrates from the CSTRs and the Slurry Concentrating Tank and from the benzene concentrations in the off-gas of these tanks. In this assessment, the decomposition of TPB is indicated by the production rate of benzene. During decomposition, each phenyl group that is removed from a TPB molecule can potentially produce a benzene molecule. If a TPB molecule is completely decomposed, four molecules of benzene could be produced. Calculated decomposition rates are illustrated in Figs. 24-28 as benzene generation rates (expressed as grams of benzene per liter of reactor volume per hour). Figure 24 shows the CSTR 1 results and gives the benzene rate based on the concentration of benzene in the vessel off-gas. The target rate for decomposition of TPB for the test was $10 \mathrm{mg}$ benzene/(L·h) based on the complete decomposition of TPB. Because of the lack of catalyst for 1PB decomposition and the difficulty in analyzing for $2 \mathrm{~PB}$, decomposition rates are based primarily on the 


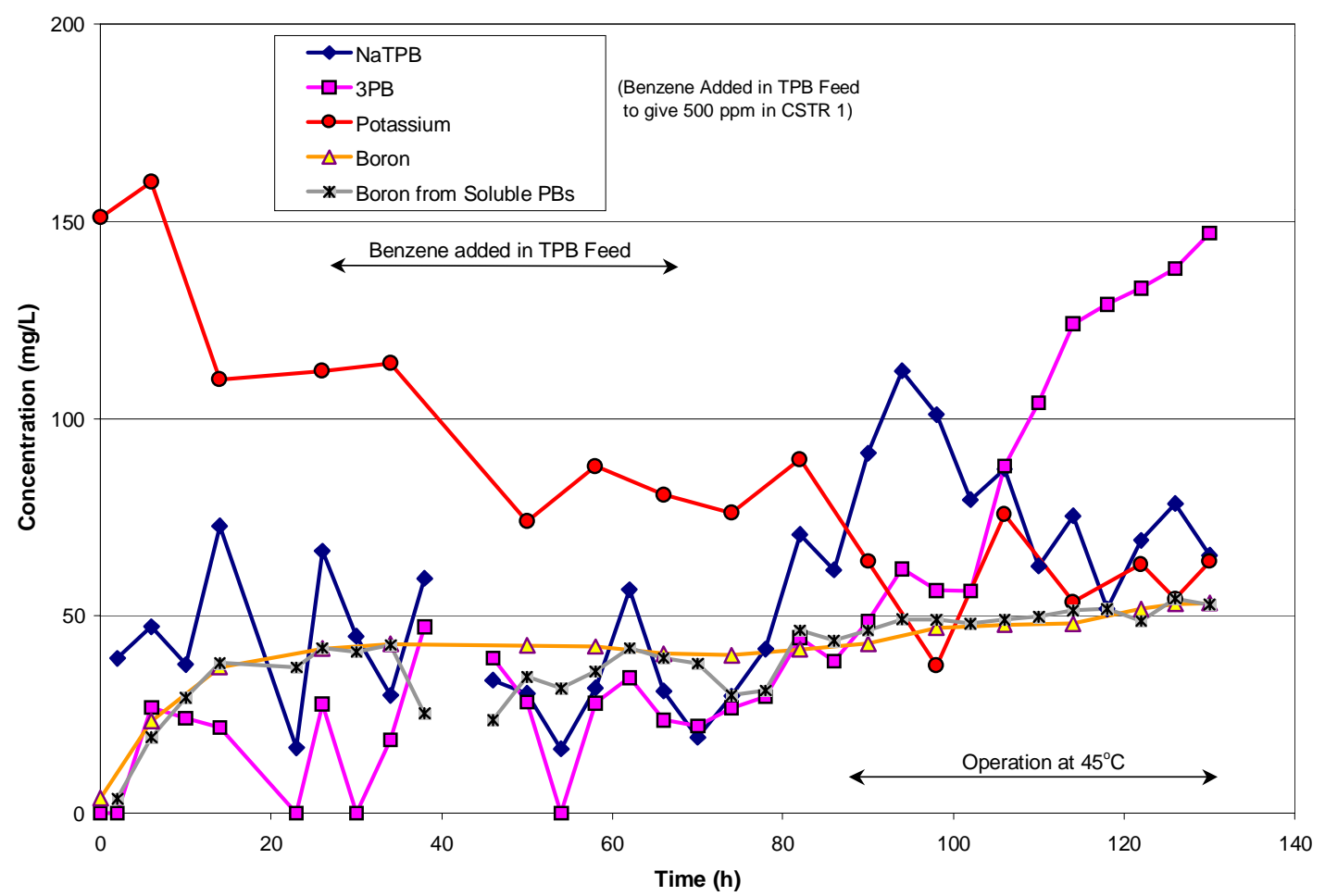

Fig. 20. CSTR 1 boron and potassium analysis results for Test 4.

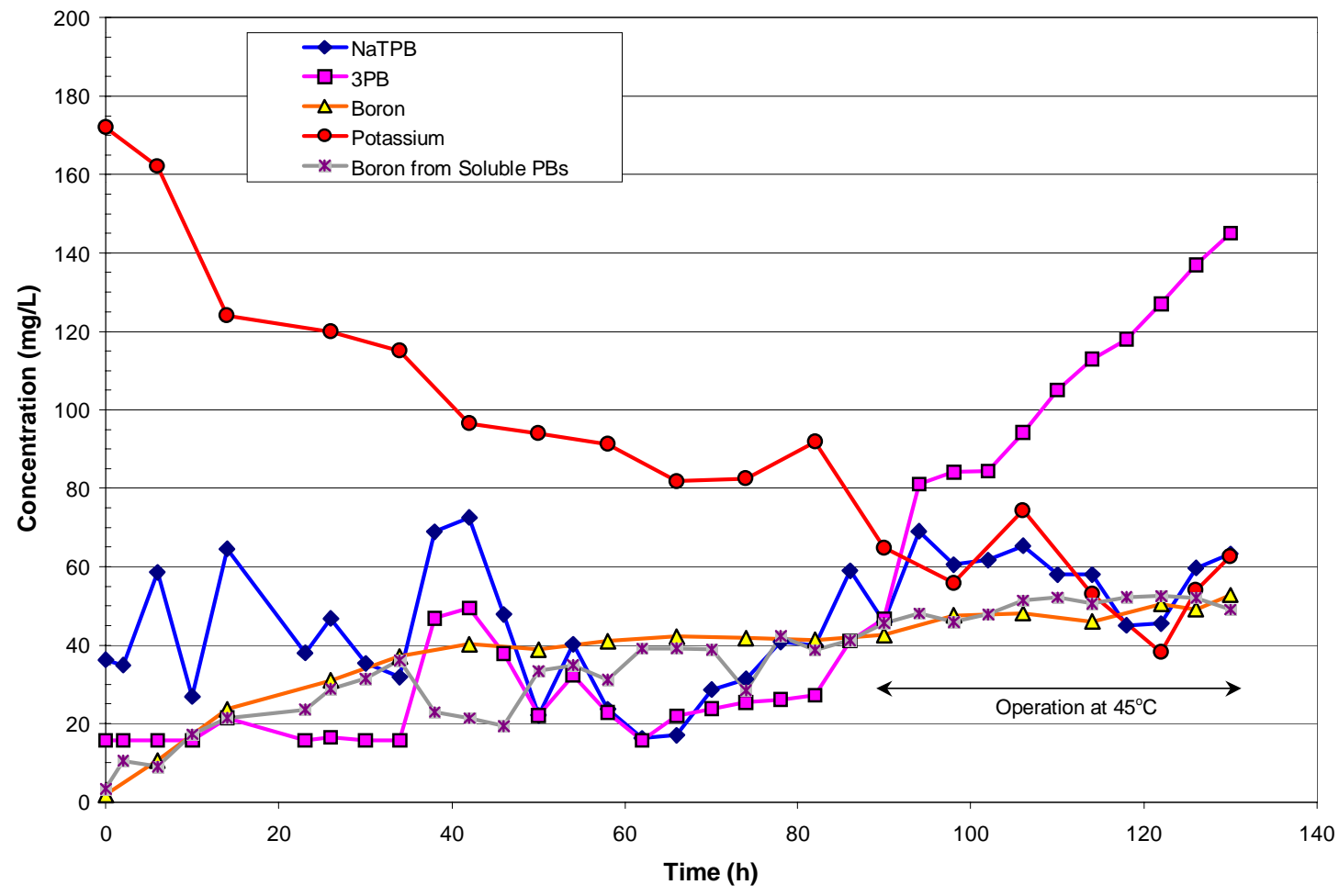

Fig. 21. CSTR 2 boron and potassium analysis results for Test 4. 


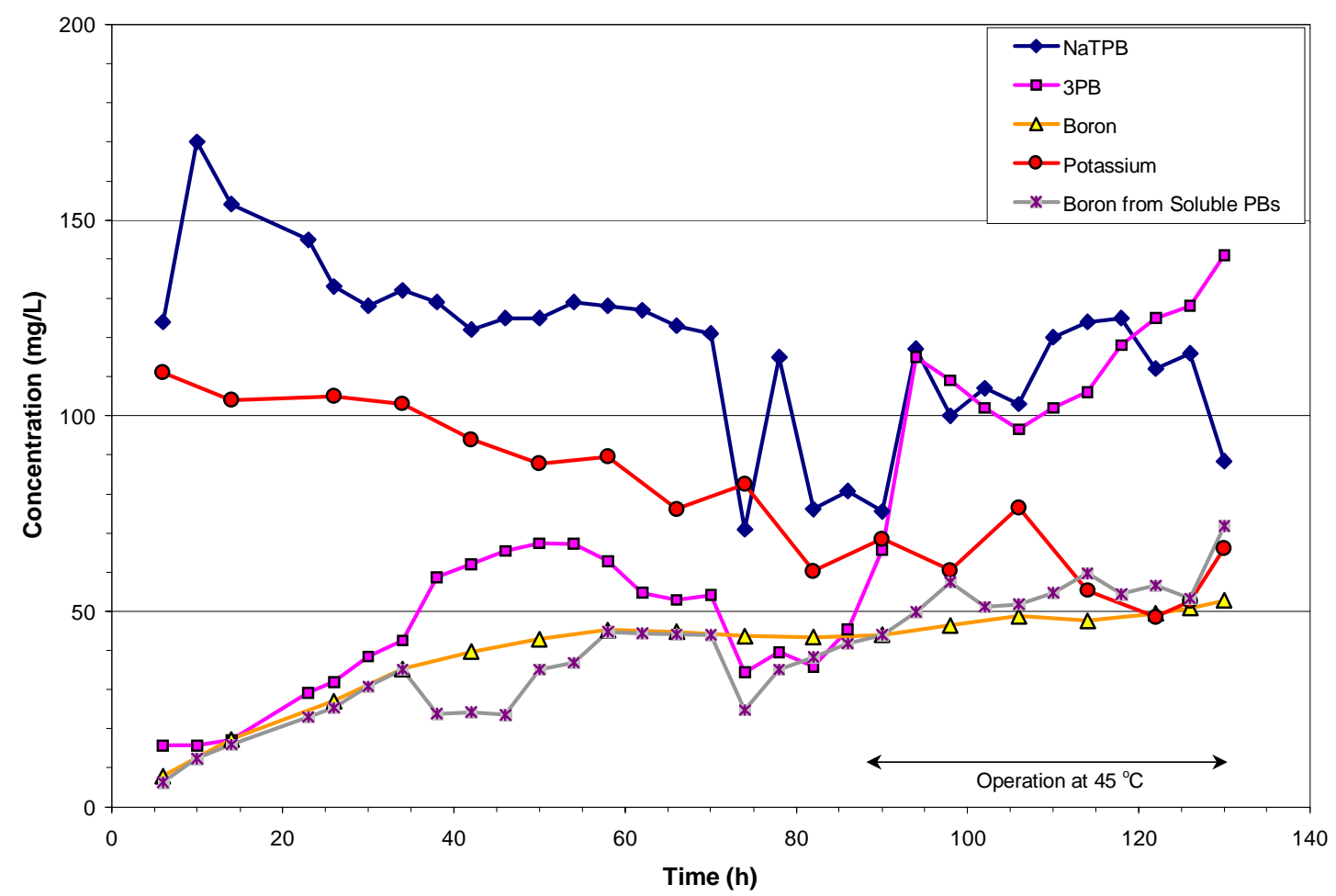

Fig. 22. Concentrate filtrate boron and potassium analysis results for Test 4 .

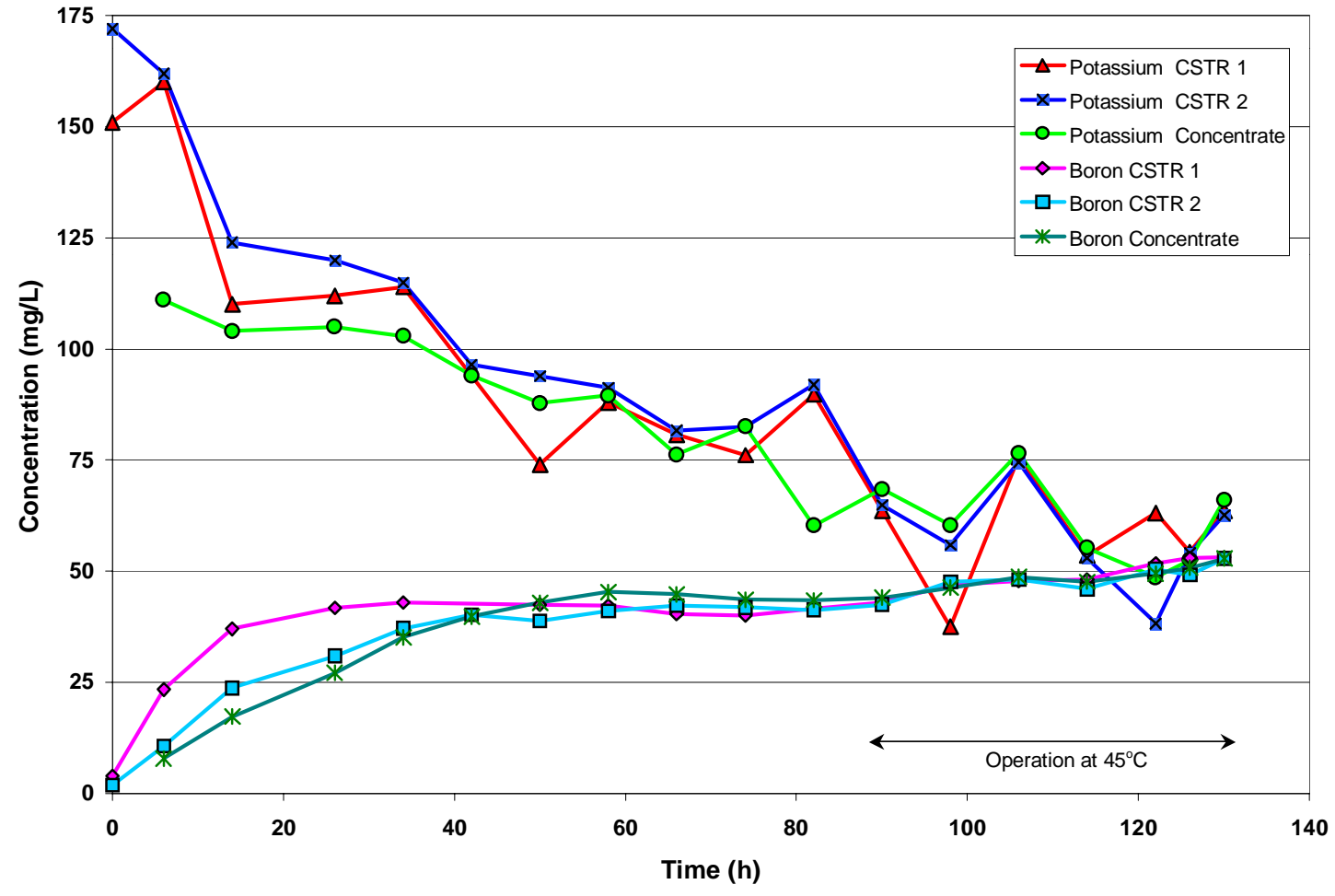

Fig. 23. Boron and potassium analysis results for Test 4. 


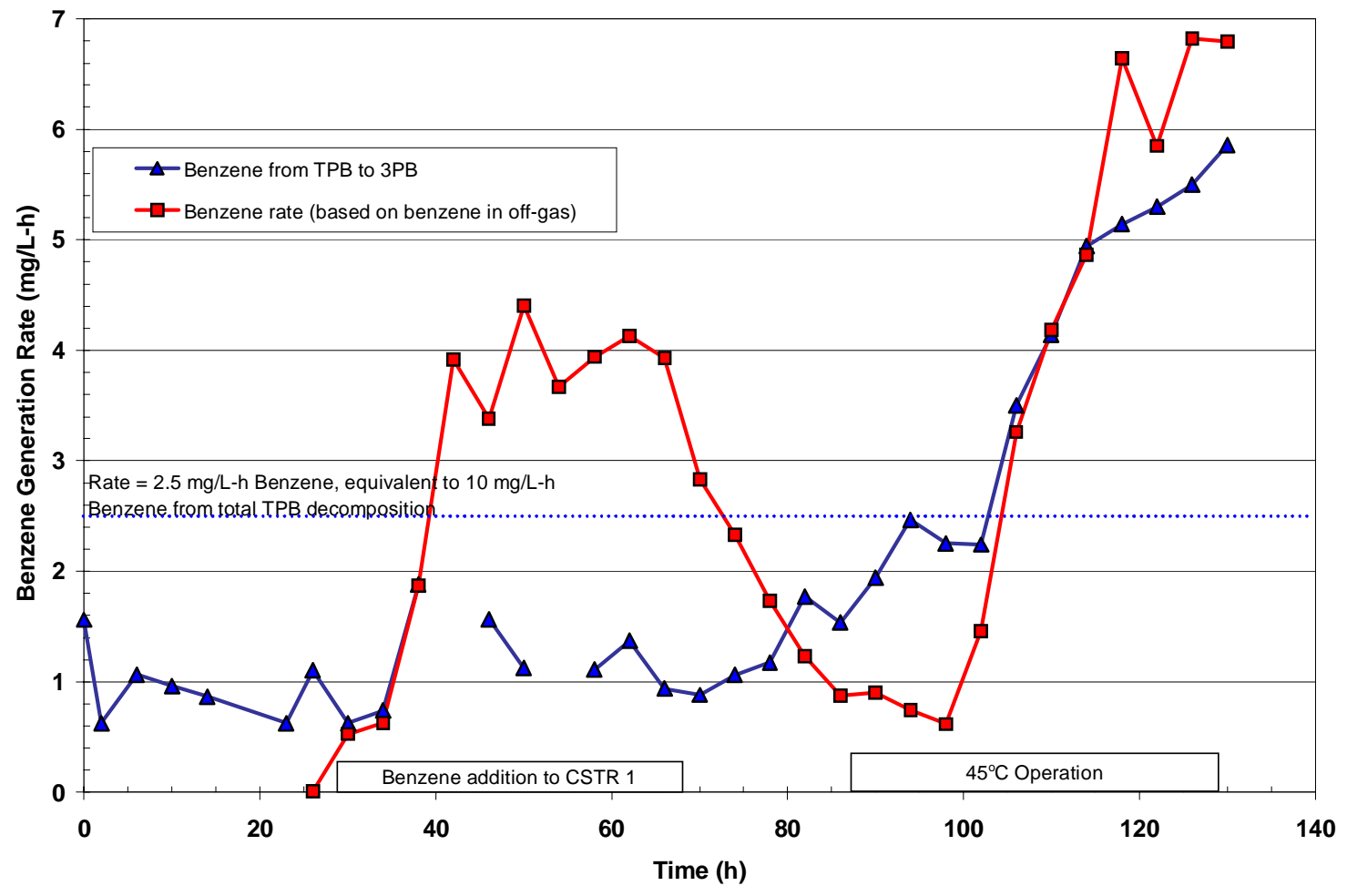

Fig. 24. Test 4 CSTR 1 benzene results.

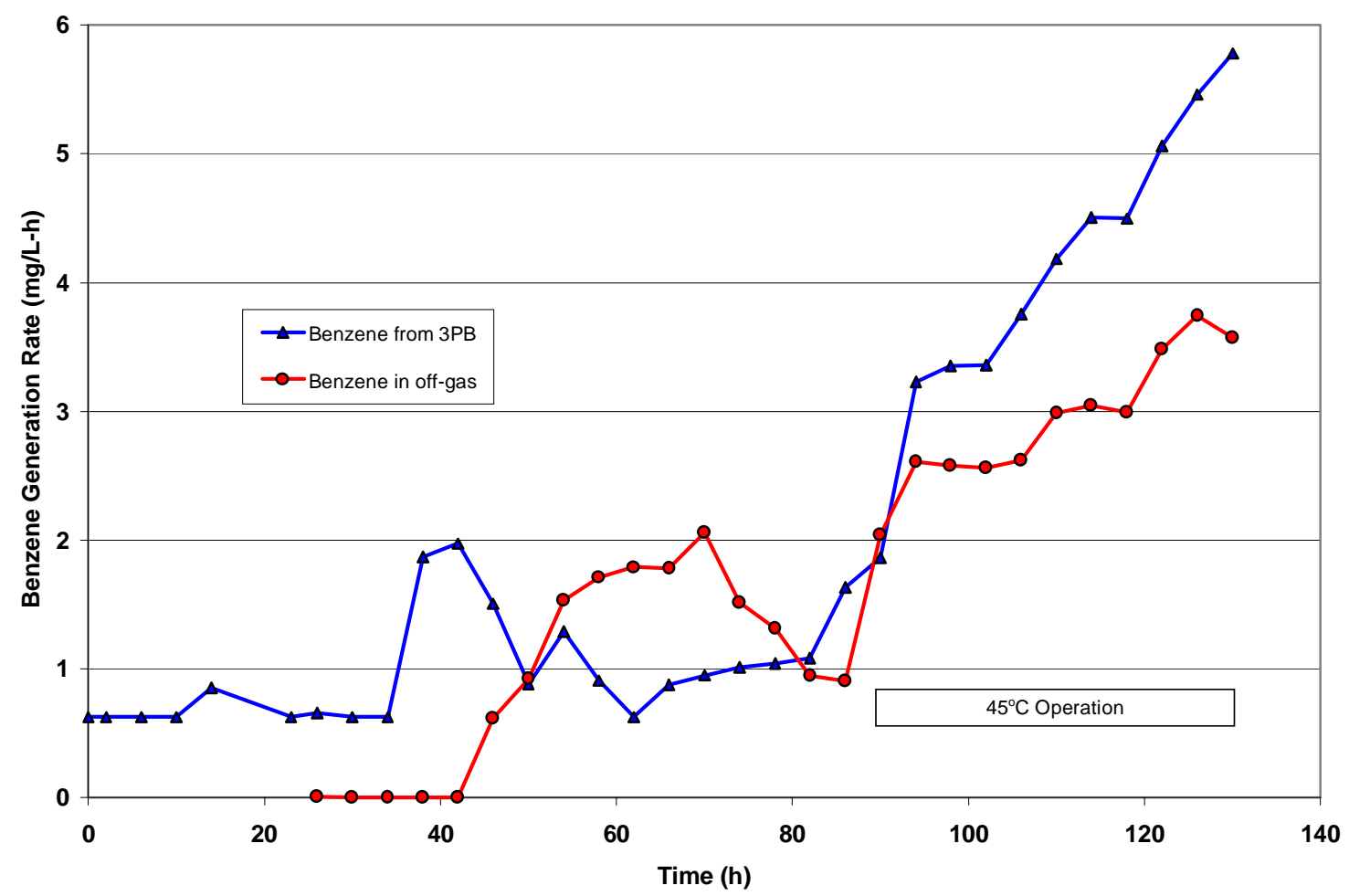

Fig. 25. Test 4 CSTR 2 benzene results. 


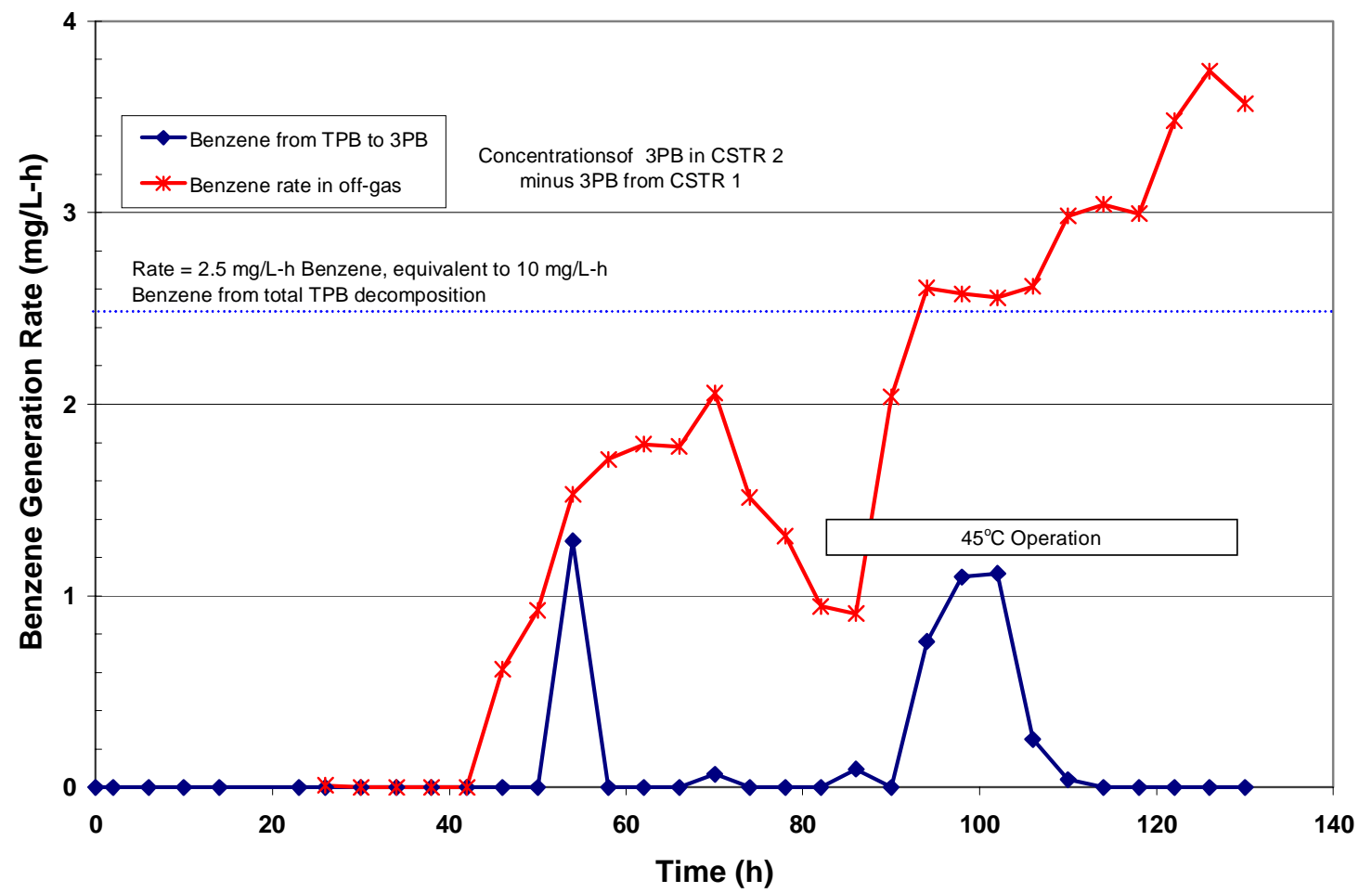

Fig. 26. CSTR 2 HPLC results for Test 4, subtracting CSTR 1 values from those in CSTR 2.

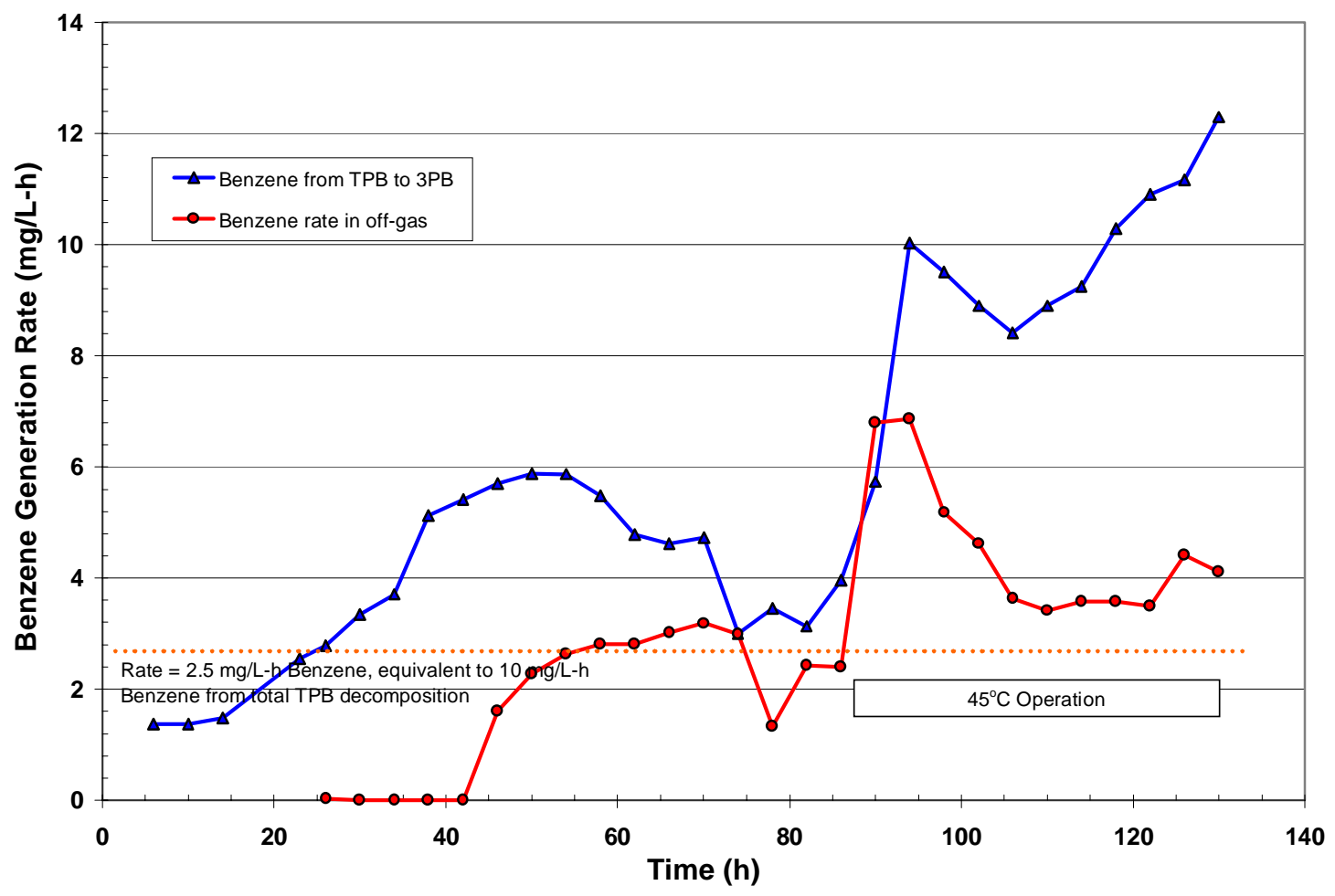

Fig. 27. Test 4 Slurry Concentrating Tank benzene results. 


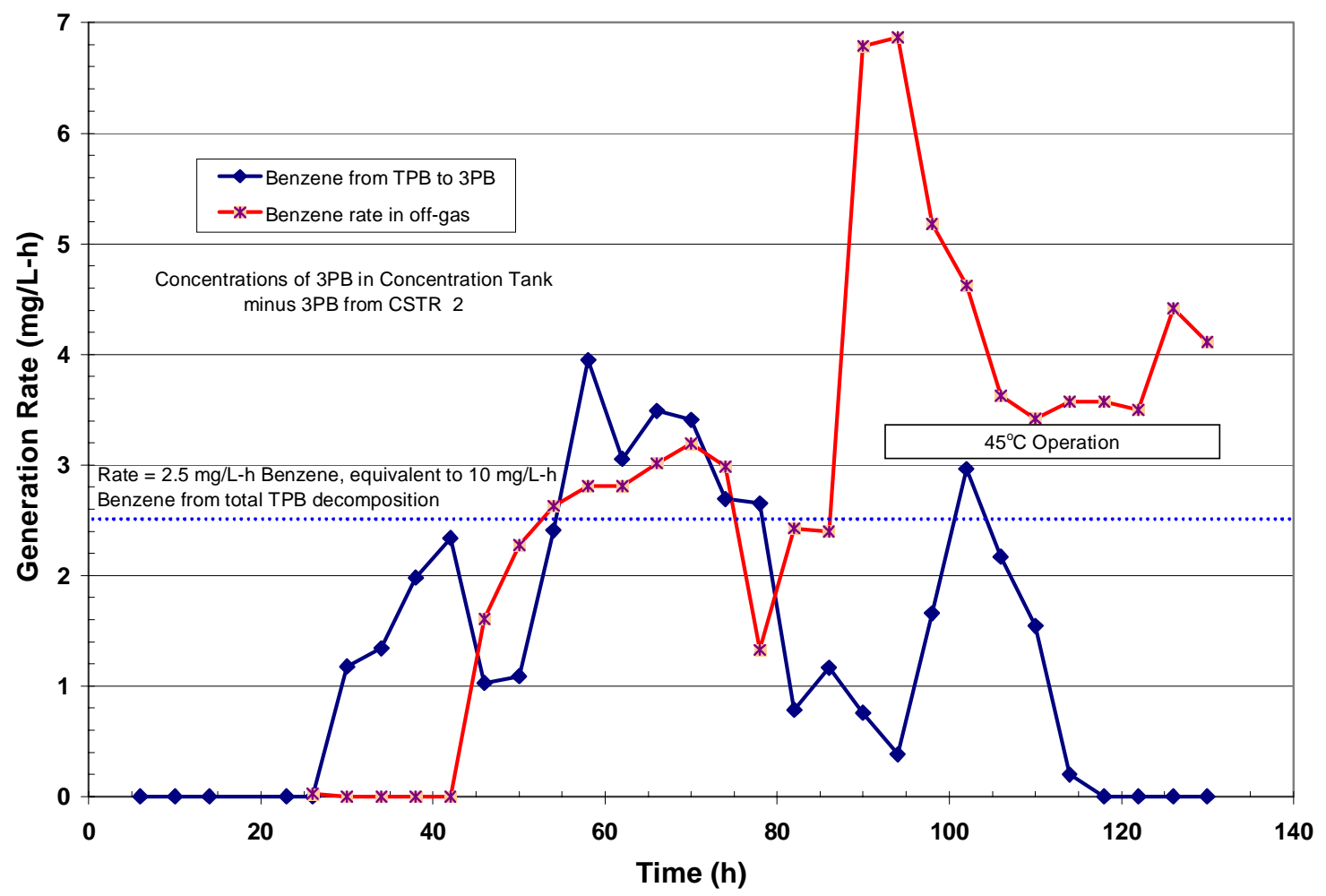

Fig. 28. Concentrate filtrate benzene results for Test 4, subtracting CSTR 2 values from those in the filtrate.

analysis of $3 \mathrm{~PB}$, the reaction of TPB with $3 \mathrm{~PB}$, producing 1 benzene molecule. As shown, there was a small generation rate (based on the production of $3 \mathrm{~PB}$ from TPB), even before benzene was added to the tank. During the last $30 \mathrm{~h}$ of operation at $45^{\circ} \mathrm{C}$, the rates based on reaction of TPB with $3 \mathrm{~PB}$ and those based on the benzene in the off-gas closely agreed. Since the conditions that impact the solubility of benzene in the process fluid are not known, it is impossible to predict the expected concentration of benzene in the off-gas from the vessel at any particular time. One would anticipate, however, the presence of a measurable quantity of benzene in the off-gas and an overall increasing trend in the benzene content of the off-gas while the rate of TPB decomposition is increasing.

For CSTR 2, the benzene generation rates (Fig. 25) that are based on 3PB are similar to those obtained for CSTR 1. Benzene generation based on the 1PB concentration is not meaningful, because 1PB was artificially added as a separate feed. The calculated benzene generation rates based on the 3PB concentrations were significant during the first few hours, although no significant benzene was measured in the vessel off-gas until after about $50 \mathrm{~h}$. The benzene rates based on the off-gas concentration after $50 \mathrm{~h}$ of operation compare closely with those calculated from the concentrations of 3PB in the filtrate samples. If it is assumed that the concentration of 3PB in CSTR 1 overflowing into CSTR 2 does not change, then that concentration can be subtracted from the CSTR 2 concentration to calculate the actual generation rate of the decomposition products in CSTR 2. The actual rate in CSTR 2 was significantly less than that calculated from the concentration of 3PB present. This is shown in Fig. 26, which indicates that the 3PB concentration was zero during most of the test. No 3PB was added to CSTR 1 via any of the supply feeds, and concentrations of $3 \mathrm{~PB}$ at the start of the test were below the detection limit.

In the Slurry Concentrating Tank, the rates based on $3 \mathrm{~PB}$ were similar to, but higher than, those in CSTR 2 (Fig. 27). The rates are calculated based on the smaller volume-and therefore faster throughput-in the Slurry Concentrating Tank versus the CSTRs. The rates based on 3PB present in the filtrate were significant within the first $24 \mathrm{~h}$, although benzene production based on off-gas analysis was 
not seen until after about $50 \mathrm{~h}$. The benzene rates based on the off-gas concentration compare closely with those calculated from the concentrations of $3 \mathrm{~PB}$ in the samples during the first batch of slurry at $25^{\circ} \mathrm{C}$. If it is assumed that the concentrations of $3 \mathrm{~PB}$ that enter the Slurry Concentrating Tank from CSTR 2 are subtracted from filtrate concentrations, then the rates are determined from the differences. When this is done, the benzene production rate in the Slurry Concentrating Tank is greatly reduced because some of the resultant concentrations are zero. Figure 28 shows that the production of benzene from $3 \mathrm{~PB}$ in the Slurry Concentrating Tank is nearly zero during most of the test, indicating that most of the TPB decomposition to 3PB is occurring in CSTR 1.

The test results of the GASMET FTIR analyzers are shown in Figs. 29-31. Figure 29 shows an overall view of the $130 \mathrm{~h}$ of operation. The benzene concentration in the CSTR 1 off-gas declined after the benzene in the feed was stopped at 13:45 on 10/12/00 (or the 68th hour of the test). At 10:30 on $10 / 13 / 00$ (the 88th hour), the temperature of the slurries reached $45^{\circ} \mathrm{C}$. The increase in benzene generation is clearly visible for the remainder of the test. Figure 30 is an expanded view of the first part of the test at $25^{\circ} \mathrm{C}$, and Fig. 31 shows the test while the slurries are being heated to and maintained at $45^{\circ} \mathrm{C}$. The spikes represent times where the FTIRs were "zeroed" and calibrated. During the high-temperature portion of the test, the benzene concentration in the CSTR 1 off-gas was $\sim 300$ ppm higher than during the $25^{\circ} \mathrm{C}$ operation when benzene was being added to the CSTR with the TPB feed. Benzene off-gas concentrations for CSTR 2 were also higher during the high-temperature portion. The concentration of benzene in the Slurry Concentrating Tank off-gas rose slowly during the $25^{\circ} \mathrm{C}$ period. The concentration then remained fairly constant during high-temperature operation-after a peak when the slurry was transferred and the Slurry Concentrating Tank was refilled, an interval during which the slurry was not circulated through the filter system. These data clearly show that the TPB decomposition reaction was more active when the temperature was elevated.

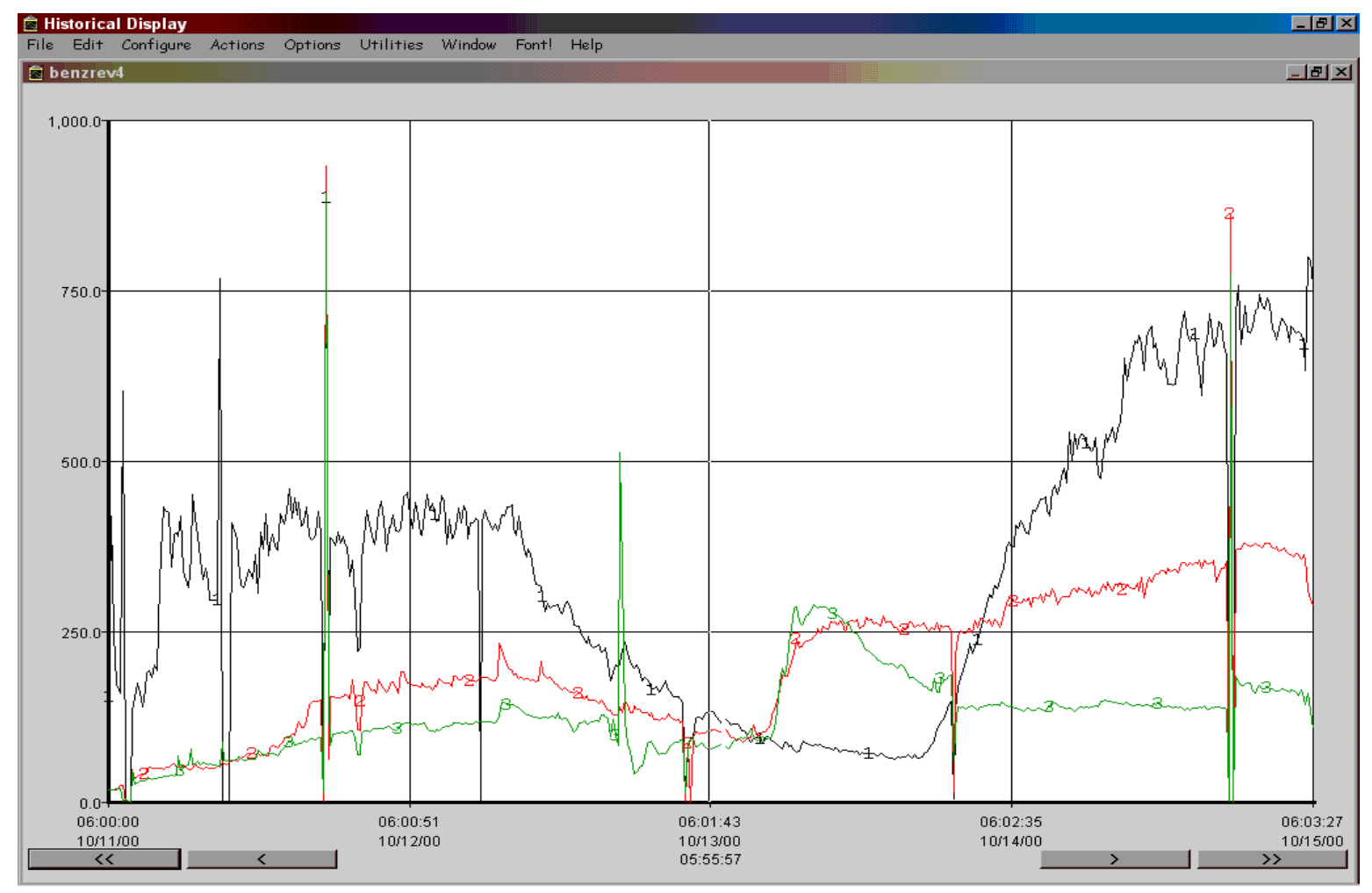

Fig. 29. Test 4 benzene analyzer results.

(Four-day overview. Black-CSTR 1, Red-CSTR 2, Green-Slurry Concentrating Tank) 


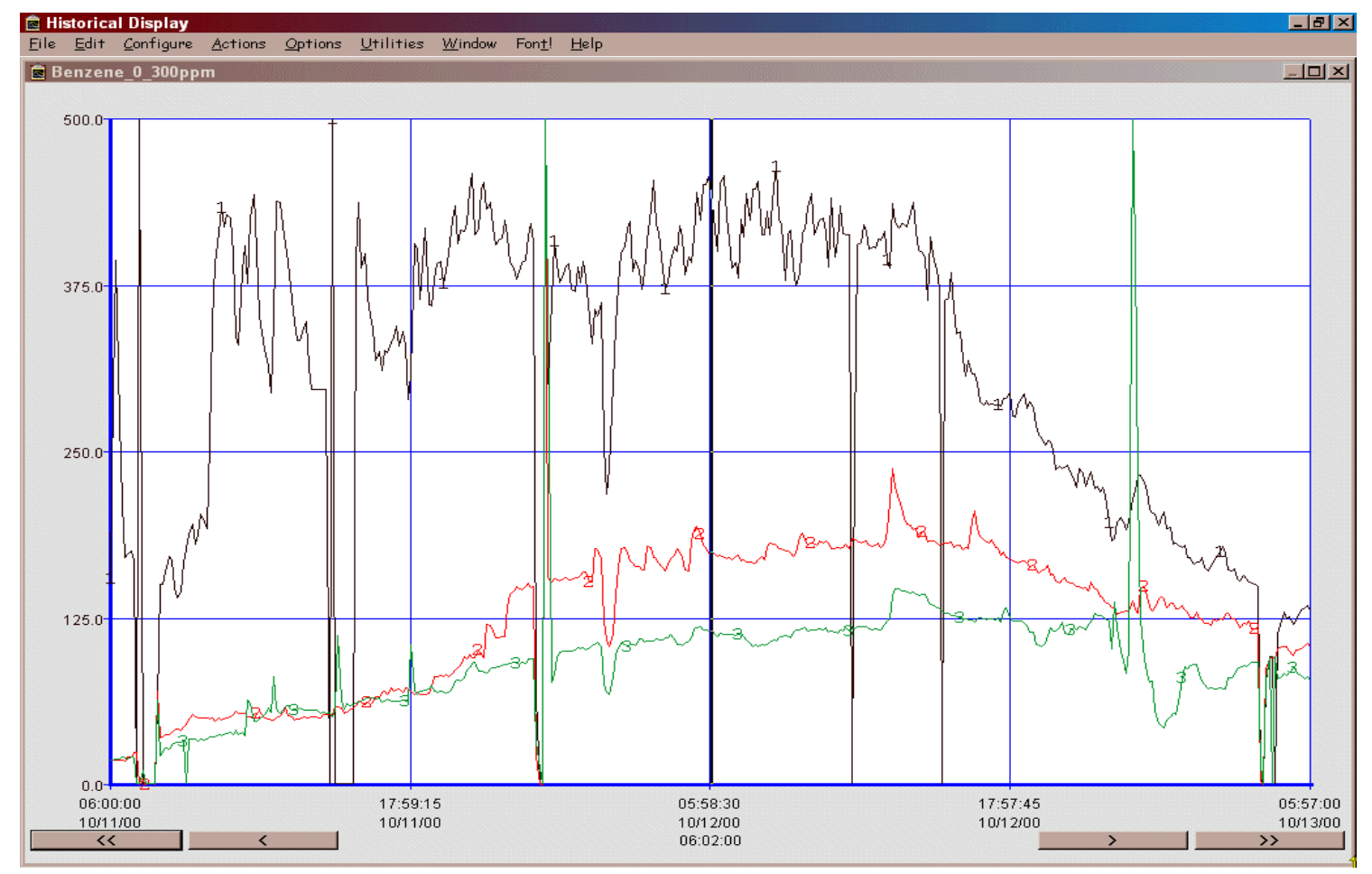

Fig. 30. Test 4 benzene analyzer results.

(Response during benzene addition. Brown-CSTR 1, Red-CSTR 2, Green-Slurry Concentrating Tank)

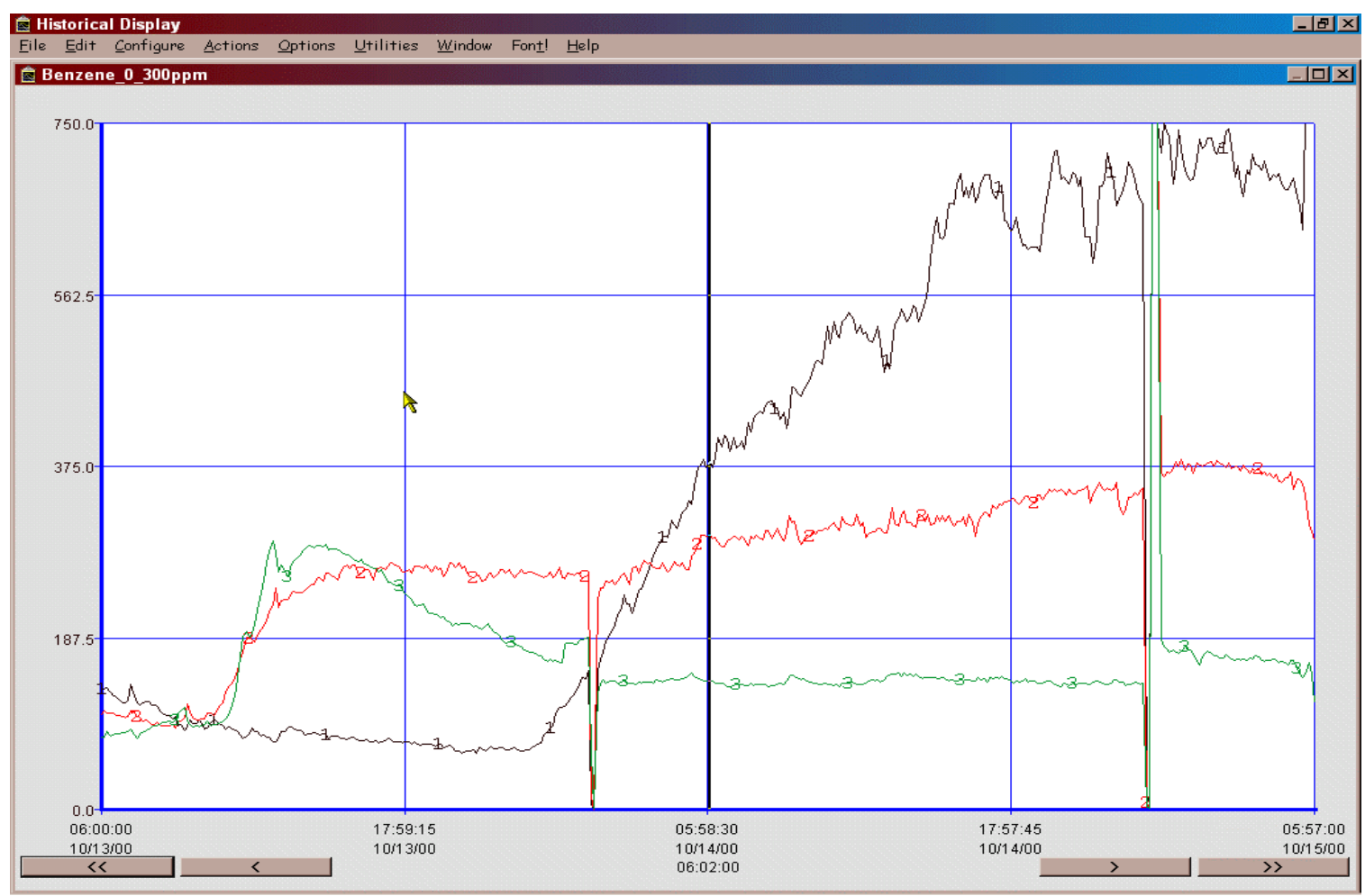

Fig. 31. Test 4 benzene analyzer results.

(Response during $45^{\circ} \mathrm{C}$ operation. Brown-CSTR 1, Red-CSTR 2, Green-Slurry Concentrating Tank) 


\subsubsection{Material Balances}

The feed supply streams to the CSTR system are shown in Figs. 32 and 33. Figure 32 shows the average flow rates for the several feeds. The flow averages were calculated only during the times when the feed systems were operational. Therefore, for the 5-h period that the system was down (hours 18-23), a horizontal line is shown on all of the feed inputs. The horizontal line readings for filtrate rate at $78 \mathrm{~h}$ (Fig. 33) resulted from the transfer of slurry to the Slurry Washing Tank and the time required to refill the Slurry Concentrating Tank. The wide variability in the filtrate flow rate results from the fluctuations that occur when the cell door is opened to remove samples or change filtrate collection tanks. The change in pressure inside the cell changed the level probe readings in the Slurry Concentrating Tank (a dp level probe) and caused the level controller to adjust the filtrate flow rate to compensate for the changed level reading. The flow interruption in the catalyst/MST graph at about $98 \mathrm{~h}$ resulted from the plugging of the catalyst/MST feed line. To continue flow, the line was connected to the NaTPB line.

Additional information on the feed to the system is shown in Fig. 33. It shows the cumulative totals of each feed stream during the course of the test. The salt feed plot shows an increase in feed rate during the final $12 \mathrm{~h}$ of the test, even though the feed pump speed had not been changed. This indicated that additional feed was being lost due to a leak in the feed tank. The filtrate curve shows the zero-flow point when the slurry was transferred to the Slurry Washing Tank and the Slurry Concentrating Tank was refilled at about $78-80 \mathrm{~h}$ of operation. All of the curves show that the feed stopped at hours 18-23. The loss of catalyst/MST feed during hours 98-101 shows up as the horizontal red series of points. Also, the feed required to fill the concentrate tank at the start of the test, about $5 \mathrm{~kg}$, and the analytical samples of slurry from each CSTR and filtrate from the concentrate tank (collected every $4 \mathrm{~h}$, at about $60 \mathrm{~mL}$ per sample) total about $7.3 \mathrm{~kg}$. Adding them gives about $30.3 \mathrm{~kg}$, which is in good agreement with what was fed to the system and what was removed.

Further information was obtained on the material balance for the catalyst fed to CSTR 1 during the test. Since two separate feed batches of catalyst/MST were prepared and used, separate material balances can be determined for the two parts of the test in which they were used. The liquid and solids in each bottle were separated by filtration, and samples of the filtrates were then analyzed for soluble mercury. The entire quantity of solids for each batch was then dissolved and analyzed for $\mathrm{Hg}, \mathrm{Pd}$, and $\mathrm{Ti}$. Based on the analyses, the slurry feed rate was $2.547 \mathrm{~g} / \mathrm{min}$ for batch 1 and $2.858 \mathrm{~g} / \mathrm{min}$ for batch 2 . The desired rate was $2.14 \mathrm{~g} / \mathrm{min}$, so the overall delivery rates were 119 and $134 \%$ of the targeted levels for batches 1 and 2, respectively.

Because of the uncertainty concerning the actual amounts of MST, Hg, and Pd delivered to the CSTR system, careful analyses of the remaining slurry solutions in both feed bottles were made. The first feed bottle, which was used for $56.7 \mathrm{~h}$ during the first part of the test, contained $0.775 \mathrm{~g} \mathrm{Pd}, 6.10 \mathrm{~g} \mathrm{Hg}$, and $30.7 \mathrm{~g}$ MST (air-dried weight). By subtracting this amount from the initial quantity of catalyst in the bottle, it was found that $0.703 \mathrm{~g} \mathrm{Pd}, 7.75 \mathrm{~g} \mathrm{Hg}$, and $64.1 \mathrm{~g}$ MST (air-dried weight) had been pumped to CSTR 1. On average, the delivery rates to CSTR 1 were $0.207 \mathrm{mg} \mathrm{Pd} / \mathrm{min}, 2.28 \mathrm{mg} \mathrm{Hg} / \mathrm{min}$, and $18.8 \mathrm{mg}$ MST/min. Comparing these rates with the pretest goals of $0.238 \mathrm{mg} \mathrm{Pd} / \mathrm{min}, 2.24 \mathrm{mg} \mathrm{Hg} / \mathrm{min}$, and $15.28 \mathrm{mg} \mathrm{MST} / \mathrm{min}$, it was determined that about $87 \%$ of the amount of palladium needed for the $3 \mathrm{X}$ concentration in the slurry was delivered during this time period. MST feed bottle 2 was used during the last half of the test. A similar analysis found that the delivery rates to CSTR 1 were $0.149 \mathrm{mg} \mathrm{Pd} / \mathrm{min}$, $2.35 \mathrm{mg} \mathrm{Hg} / \mathrm{min}$, and $18.4 \mathrm{mg} \mathrm{MST} / \mathrm{min}$. For this period of the test, only $63 \%$ of the amount of palladium needed for the $3 \mathrm{X}$ concentration in the slurry was delivered. Although the palladium concentration in the slurry was less than the $3 \mathrm{X}$ concentration, it certainly was enough to provide TPB decomposition, especially at $45^{\circ} \mathrm{C}$. 


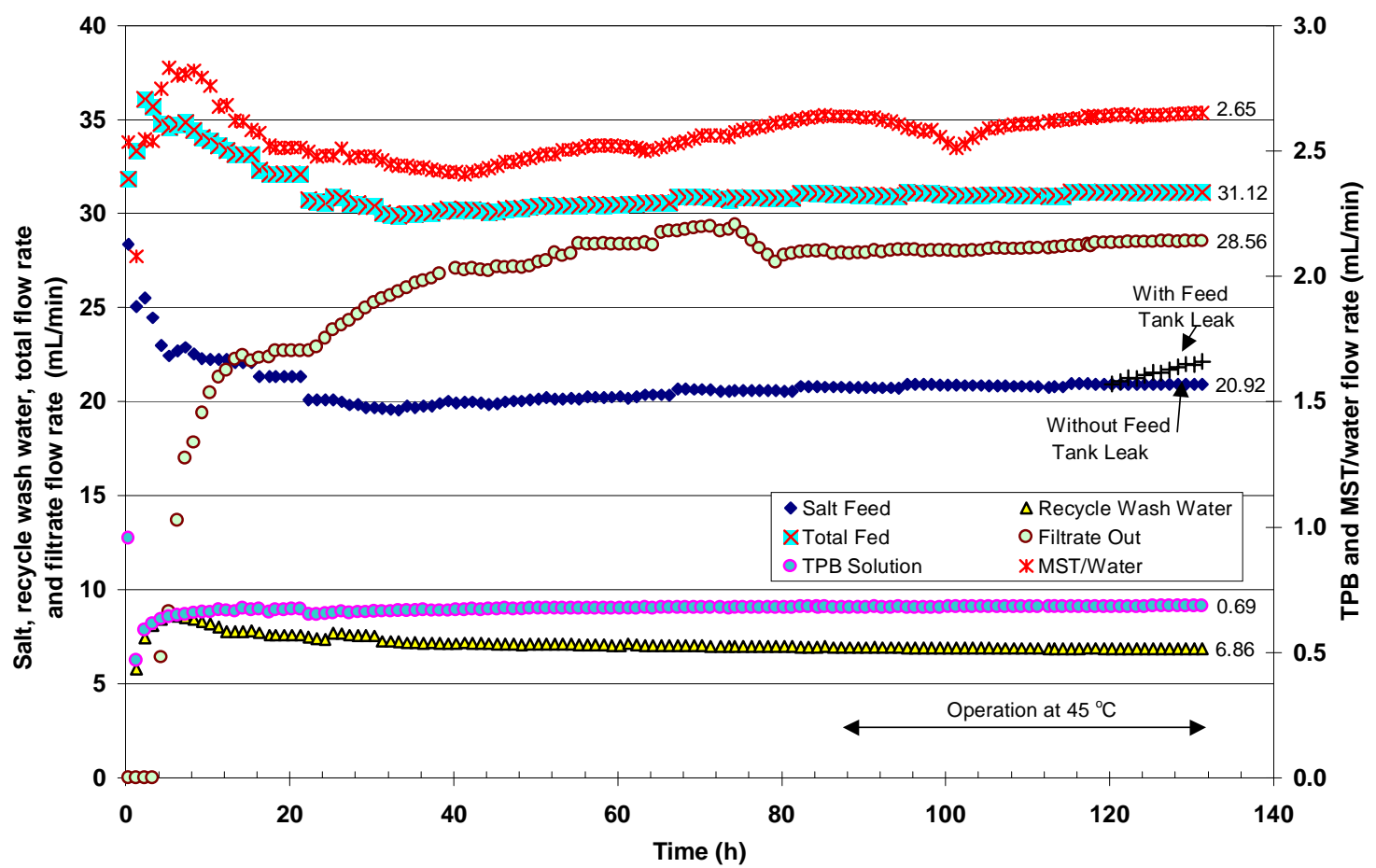

Fig. 32. Test 4 feed materials flow balance showing overall test average flow rate.

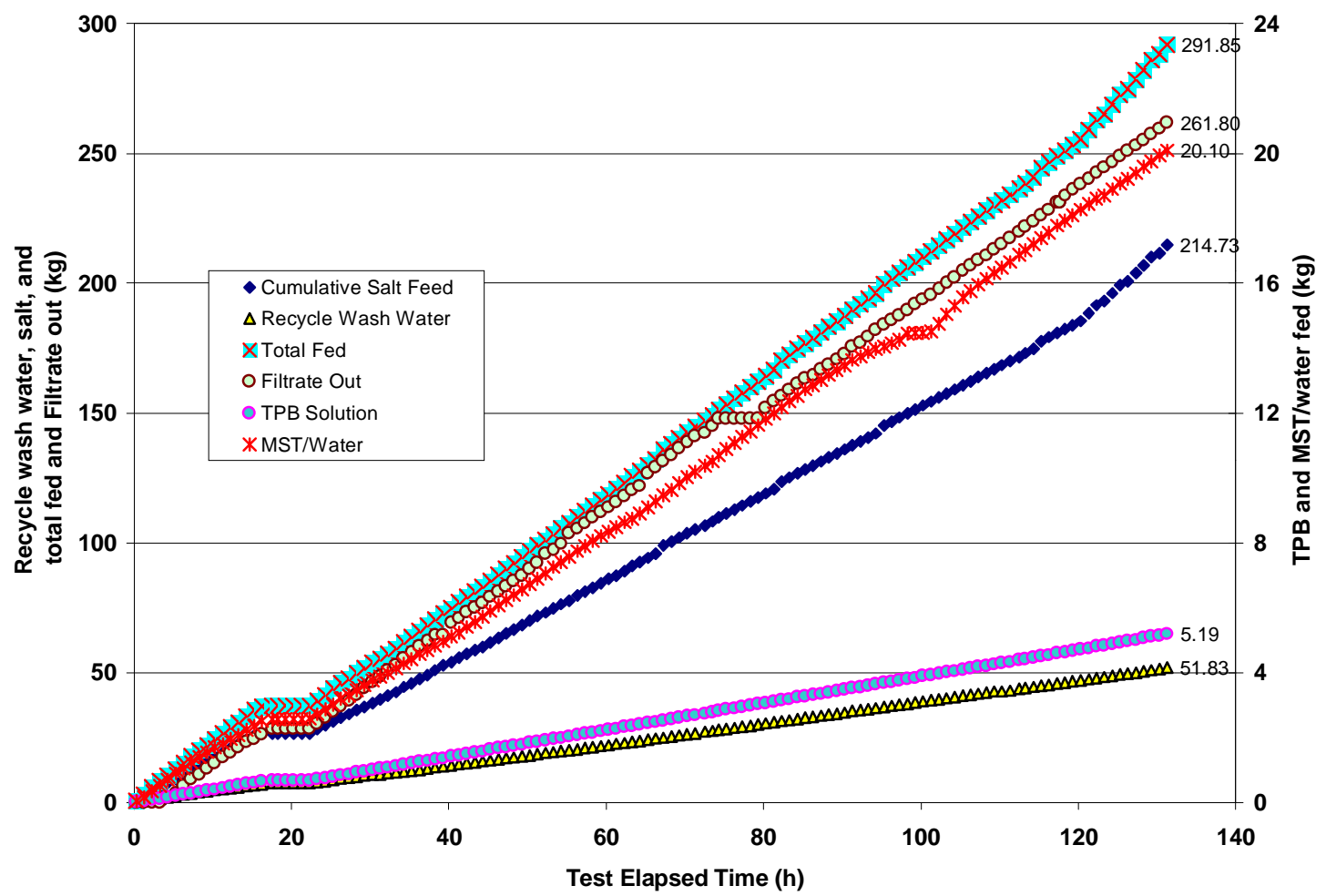

Fig. 33. Test 4 cumulative masses fed to CSTR 1. 
The results of the analyses, seen in Table 5, provide additional information for determining the feed rate of individual components of the catalyst/MST mixture. The mercury was fed at about $127 \%$ of the rate that was intended during both parts of the experiment. The amount of MST solids fed was about $124 \%$ of the planned amount for the first part and about $116 \%$ for the second part of the test. More palladium was fed during the first part due to the better suspension of particulates achieved in the slurry feed tank. During the second part, as noted above, the slurry tended to settle very quickly; made a large blob of sticky solids on the carboy bottom, which was very difficult to suspend; and tended to plug the feed line. It finally formed an unmovable plug at the check valve. The flow was stopped for several (4-5) $\mathrm{h}$ while the tubing was checked and the flow rerouted through the TPB line. The material balance results are shown in Table 6.

Table 5. MST makeup for Test 4

\begin{tabular}{|c|c|c|c|c|}
\hline & $\begin{array}{l}\text { Mass added } \\
\text { to bottle } \\
(\mathrm{g})\end{array}$ & $\begin{array}{l}\text { Mass added } \\
\text { (mg/g MST } \\
\text { slurry) }\end{array}$ & $\begin{array}{c}\text { Mass } \\
\text { delivered } \\
(\mathrm{g}) \\
\end{array}$ & $\begin{array}{c}\text { Mass delivered } \\
\text { (mg/g MST } \\
\text { slurry) }\end{array}$ \\
\hline \multicolumn{5}{|l|}{ MST Bottle \#1 } \\
\hline Wet MST & 220.23 & & & \\
\hline Air-dried MST & 94.8 & 7.140 & 64.1 & 7.4 \\
\hline $\mathrm{Hg}\left(\mathrm{NO}_{3}\right)_{2} \cdot \mathrm{H}_{2} \mathrm{O}$ & 27.61 & & & \\
\hline Elemental mercury & 13.89 & 1.046 & 7.75 & 0.895 \\
\hline Palladium on alumina & 29.56 & & & \\
\hline Elemental palladium & 1.478 & 0.1113 & 0.703 & 0.0812 \\
\hline Water & 13,000 & & & \\
\hline Total slurry \#1 & $13,277.4$ & & 8,656 & \\
\hline \multicolumn{5}{|l|}{ MST Bottle \#2 } \\
\hline Wet MST & 270.8 & & & \\
\hline Air-dried MST & 116.6 & 7.135 & 72.7 & 6.43 \\
\hline $\mathrm{Hg}\left(\mathrm{NO}_{3}\right)_{2} \cdot \mathrm{H}_{2} \mathrm{O}$ & 34.33 & & & \\
\hline Elemental mercury & 17.28 & 1.057 & 9.29 & 0.822 \\
\hline Palladium on alumina & 36.33 & & & \\
\hline Elemental palladium & 1.817 & 0.1112 & 0.5915 & 0.0523 \\
\hline Water & 16,000 & & & \\
\hline Total slurry \#2 & $16,341.7$ & & $11,305.1$ & \\
\hline
\end{tabular}

\subsection{SUBSYSTEMS OPERATION}

Figures 32 and 33 indicate that problems occurred with the catalyst/MST feed, especially during the latter part of the test. The plots in Figs. 34-37 from the computer data logging routine show more detail for the catalyst/MST stream and other feeds and indicate the times that the catalyst/MST flow stopped (shown by a slow decrease or sudden drop to zero flow). When flow declined below an established set point, the computer system sent an alarm that allowed the operators to begin to fix the problem immediately. Figure 36 shows the attempts to increase the slowing flow and restart the flow after it had stopped. Once flow had been restarted by feeding along with the TPB, the feed rate was set higher for several hours to compensate for the amount of catalyst/MST that should have been fed up to that time. Once the flow was restarted, no more stoppages occurred during the remainder of the test. No problems were noted with any of the other feed streams during Test 4, either in maintaining flow rate or with feed stoppages. Figure 37 shows the operational period during the test when recycle wash water from the Test 3 slurry washing was used. 


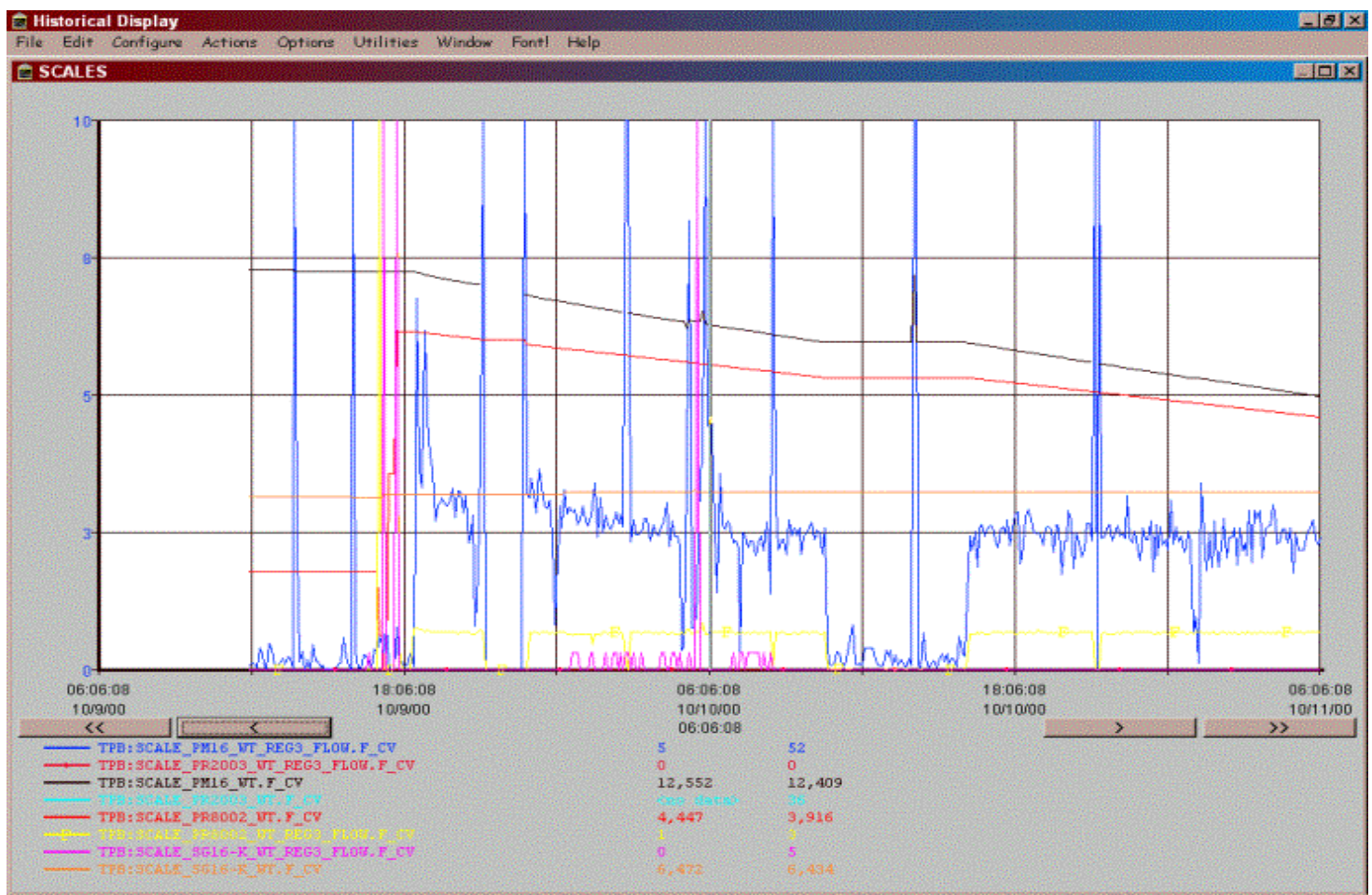

Fig. 34. TPB and MST feed rates from their balances during $25^{\circ} \mathrm{C}$ operation.

(Blue-MST/Water rate, Black—MST/Catalyst mass, Red-TPB mass, Yellow—TPB rate)

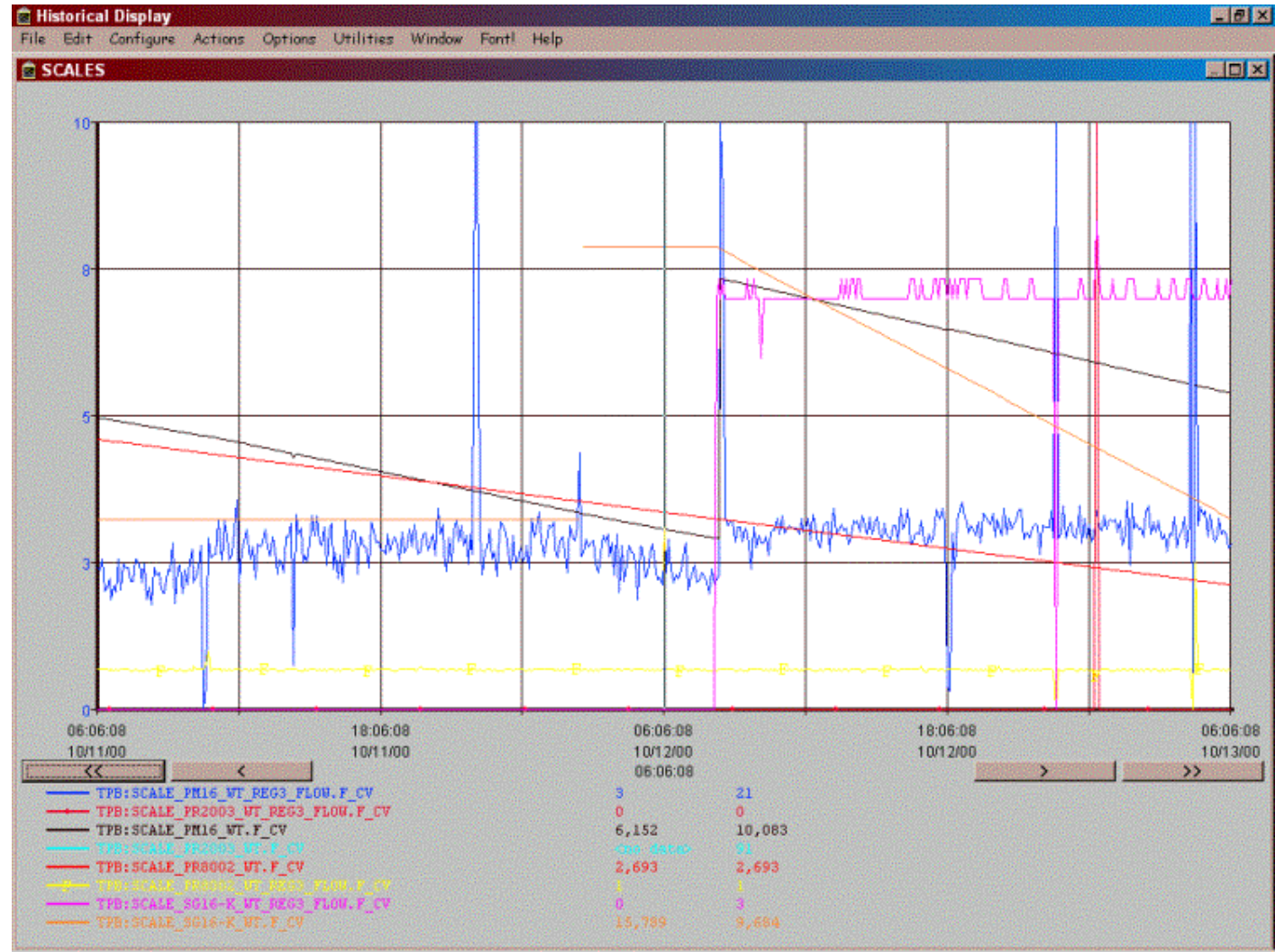

Fig. 35. TPB and MST feed rates from their balances during heatup and $45^{\circ} \mathrm{C}$ operation.

(Blue-MST/Water rate, Black—MST/Catalyst mass, Red-TPB mass, Yellow-TPB rate,

Purple-Recycle wash-water flow, Orange-Recycle wash-water mass) 


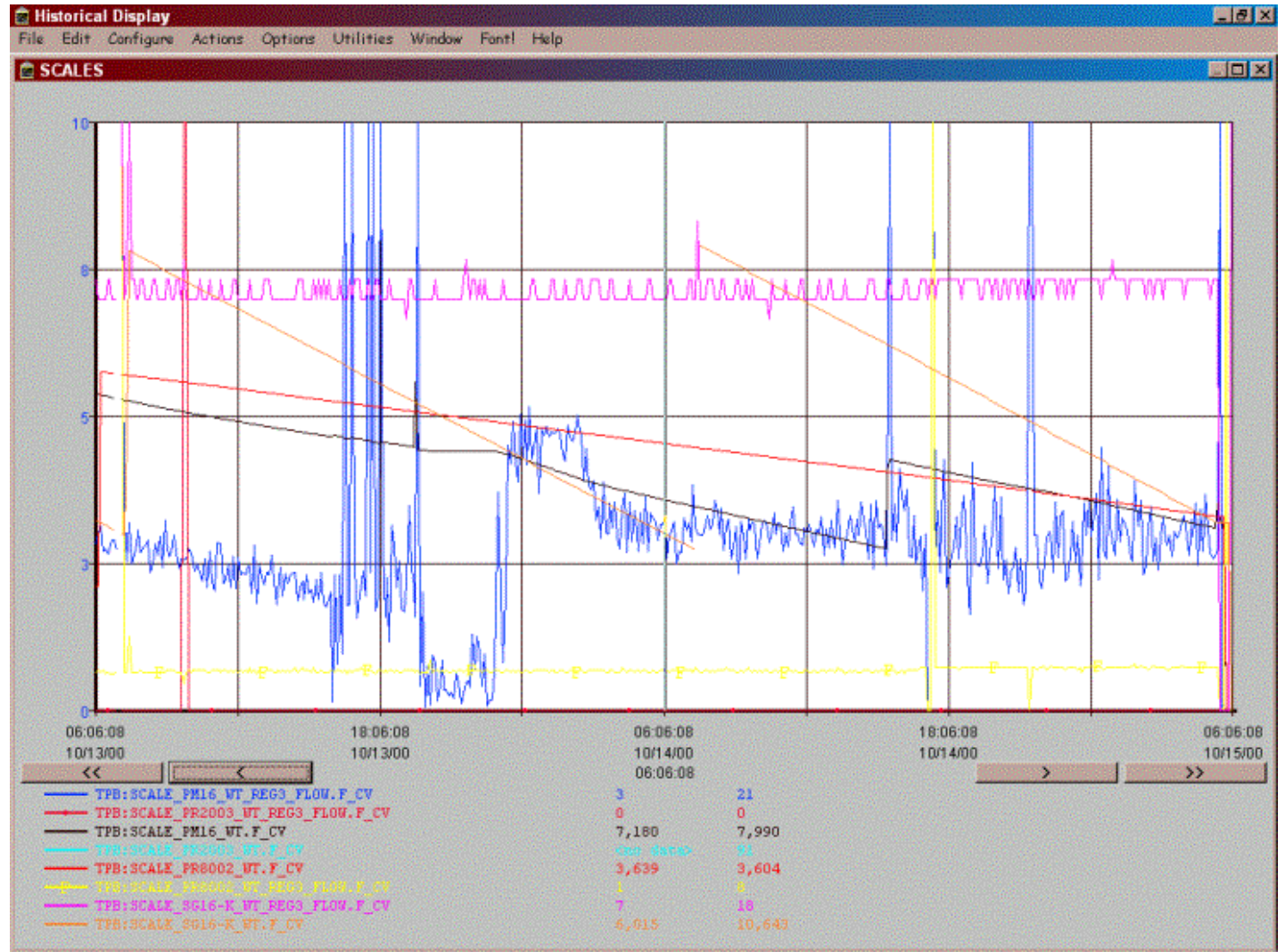

Fig. 36. TPB and MST feed rates from their balances during $45^{\circ} \mathrm{C}$ operation.

(Blue-MST/Water rate, Black-MST/Catalyst mass, Red-TPB mass, Yellow-TPB rate,

Purple-Recycle wash-water flow, Orange-Recycle wash-water mass)

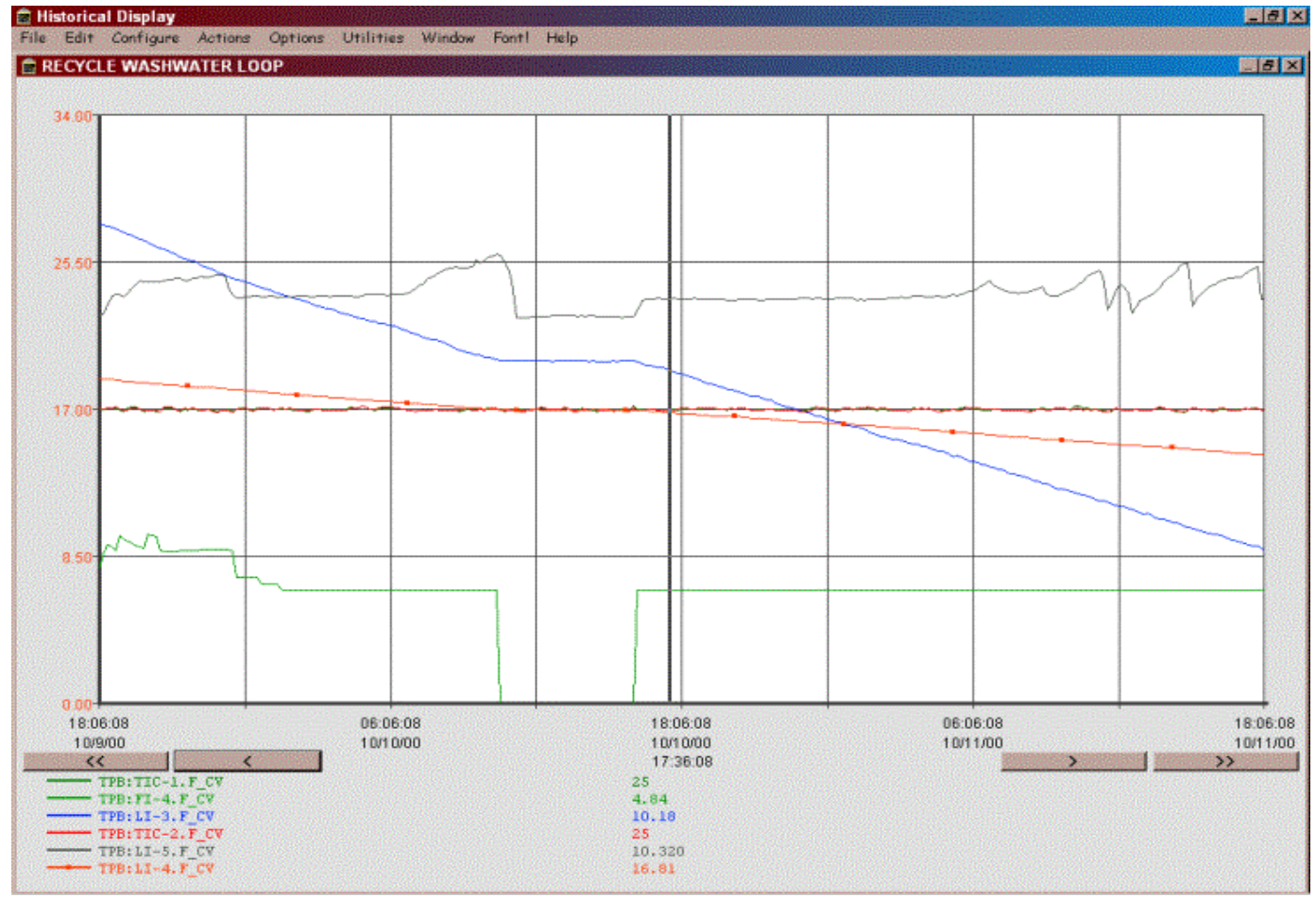

Fig. 37. CSTR 1 operation during feeding from recycle washer tank.

(Orange-Salt feed tank level, 0-34 in.; Black-CSTR 1 level, 0-15 in.;

Blue-Recycle wash-water tank level, 0-18 in.) 
Table 6. MST slurry material balance for Test 4

(Delivery to CSTR 1)

\begin{tabular}{|c|c|c|}
\hline & $\begin{array}{l}\text { Actual/targeted } \\
\text { (mg/L slurry) }\end{array}$ & $\begin{array}{c}\text { Ratio } \\
(\%)\end{array}$ \\
\hline \multicolumn{3}{|l|}{ MST Bottle $\# 1^{a}$} \\
\hline Mercury & $72.4 / 85$ & 85 \\
\hline Palladium $^{b}$ & $6.58 / 7.8$ & 84 \\
\hline MST & $597 / 490$ & 122 \\
\hline \multicolumn{3}{|l|}{ MST Bottle $\# 2^{c}$} \\
\hline Mercury & $74.0 / 85$ & 87 \\
\hline Palladium $^{d}$ & $4.76 / 7.8$ & 61.1 \\
\hline MST & $578 / 490$ & 118 \\
\hline
\end{tabular}

Figure 37 also highlights the other hydraulic problem that occurred during the test when some form of solid material partially plugged the overflow outlet from CSTR 1 to CSTR 2 and caused the CSTR 1 level to rise. When this occurred the first time and flow could not be quickly reestablished, some of the CSTR 1 slurry was pumped directly to the concentrate tank using the peristaltic pump. This pump is normally used for waste removal purposes to process the slurry remaining in the CSTRs after a test is finished. This allowed time for the system feed pumps and the slurry concentration system to be shut down and a new valve to be installed on CSTR 1 in place of the plugged valve. As Fig. 37 shows, smooth flow was established for about $12 \mathrm{~h}$ and the valve then started to plug again. Tapping on the valve at this time and subsequent plugging times and tilting the valve in the direction of CSTR 2 seemed to allow the plug material to pass on through the valve. This procedure appeared to work for the remainder of the test, and the level in CSTR 1 remained constant.

Figures 38 and 39 show the operation of the slurry concentration system during the first and second slurry batch concentrations. Figure 38 shows $25^{\circ} \mathrm{C}$ operation and the backpulses that were required when the pressure drop across the filter became too great. The first backpulse occurred during the third day of processing when the backpressure reached 40 psi and the concentration tank level could no longer be maintained. Only three backpulses were required during the course of the testing. Figure 40 shows the performance response of the filtration system after the backpulse. The third backpulse was conducted during the temperature ramp up to $45^{\circ} \mathrm{C}$, and no additional backpulses were required during operation at $45^{\circ} \mathrm{C}$. The pronounced fluctuations in the flow rate and tank level throughout the test occurred when the cell doors were opened every $4 \mathrm{~h}$ to remove the slurry samples and filtrate sample from the cell for analysis. The change in ambient pressure in the cell was detected by the level sensor in the Slurry Concentrating Tank, causing an unneeded response. This occurrence did not significantly impact the overall operation of the filter.

Figures 41 and 42 show the temperatures of the three process vessels during the $45^{\circ} \mathrm{C}$ operation. Also shown in the figures are the fluid temperatures in the temperature control circulators. The figures show the good temperature control achieved during this part of the test. 


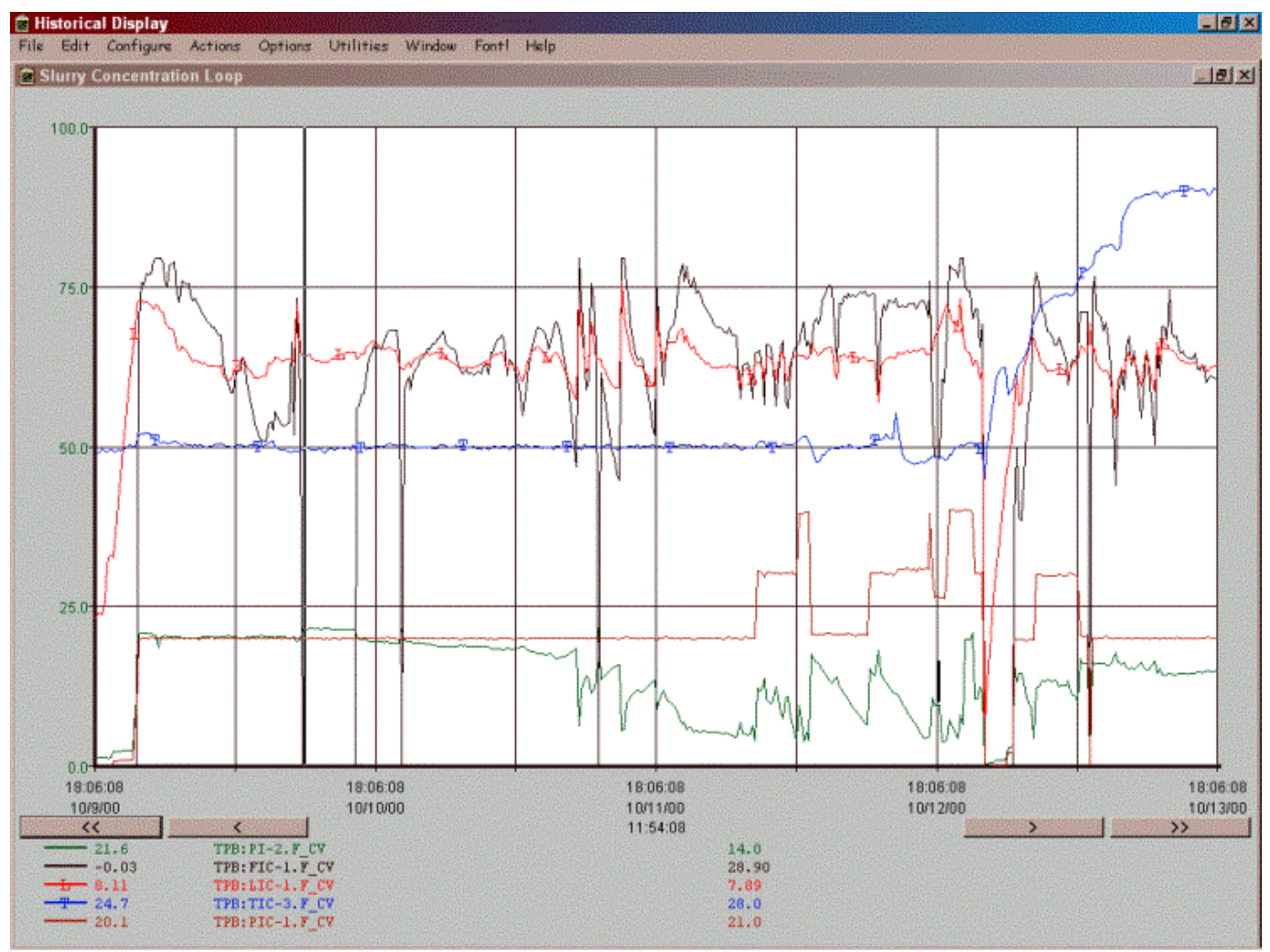

Fig. 38. Slurry concentration loop operation during Batch 1 of Test 4.

(Blue-Temperature, $0-50^{\circ} \mathrm{C}$; Black-Filtrate flow, 0-50 mL/min; Red-Tank level, 0-11 in.; Brown and green - pre- and post-filter pressure, $0-100 \mathrm{psi}$ )

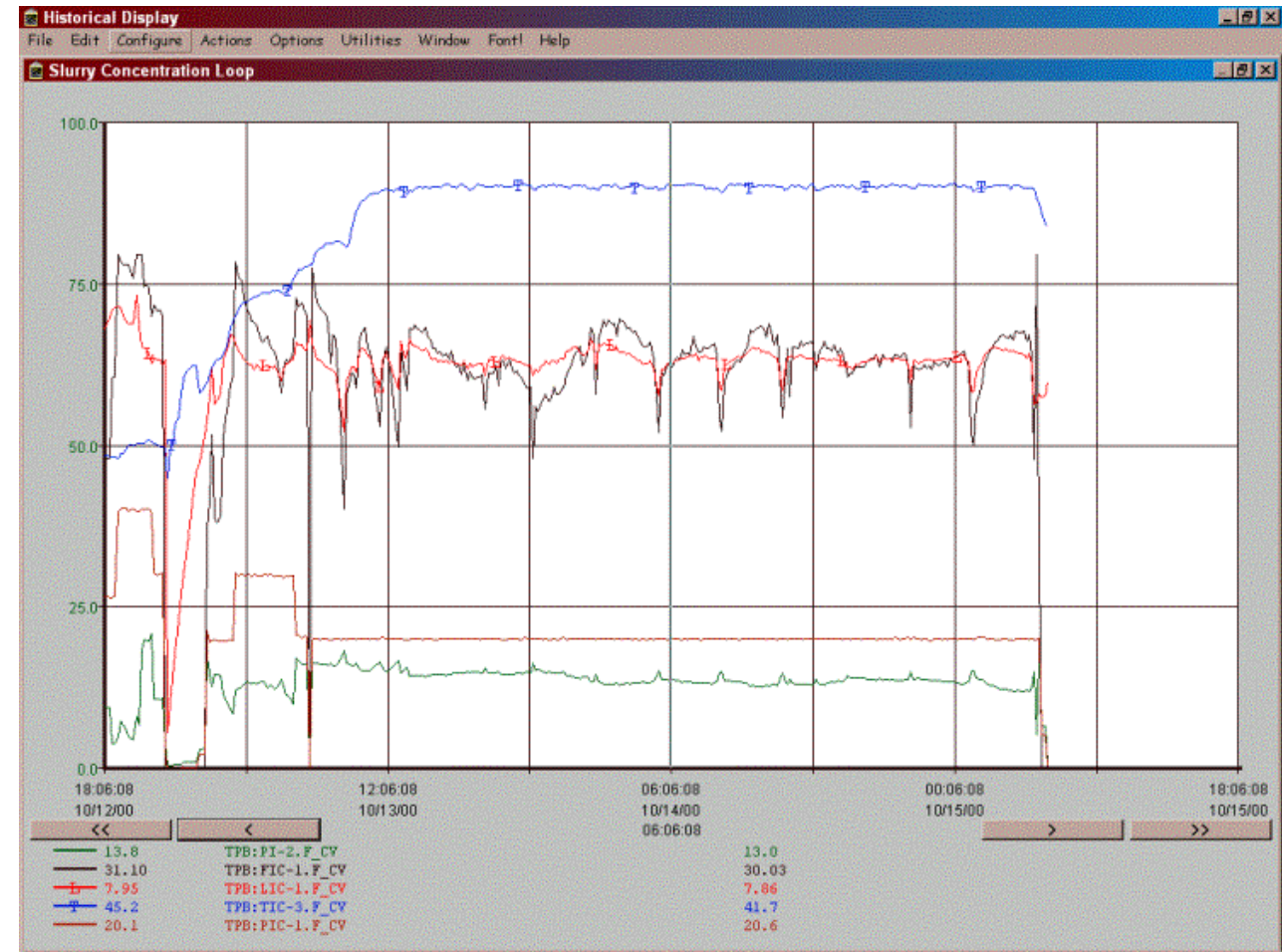

Fig. 39. Slurry concentration loop operation during Batch $2\left(45^{\circ} \mathrm{C}\right)$ of Test 4.

(Blue-Temperature, $0-50^{\circ} \mathrm{C}$; Brown and green-pre- and post-filter pressure, $0-100 \mathrm{psi}$; Black-Filtrate flow, 0-50 mL/min; Red-Tank level, 0-11 in.) 


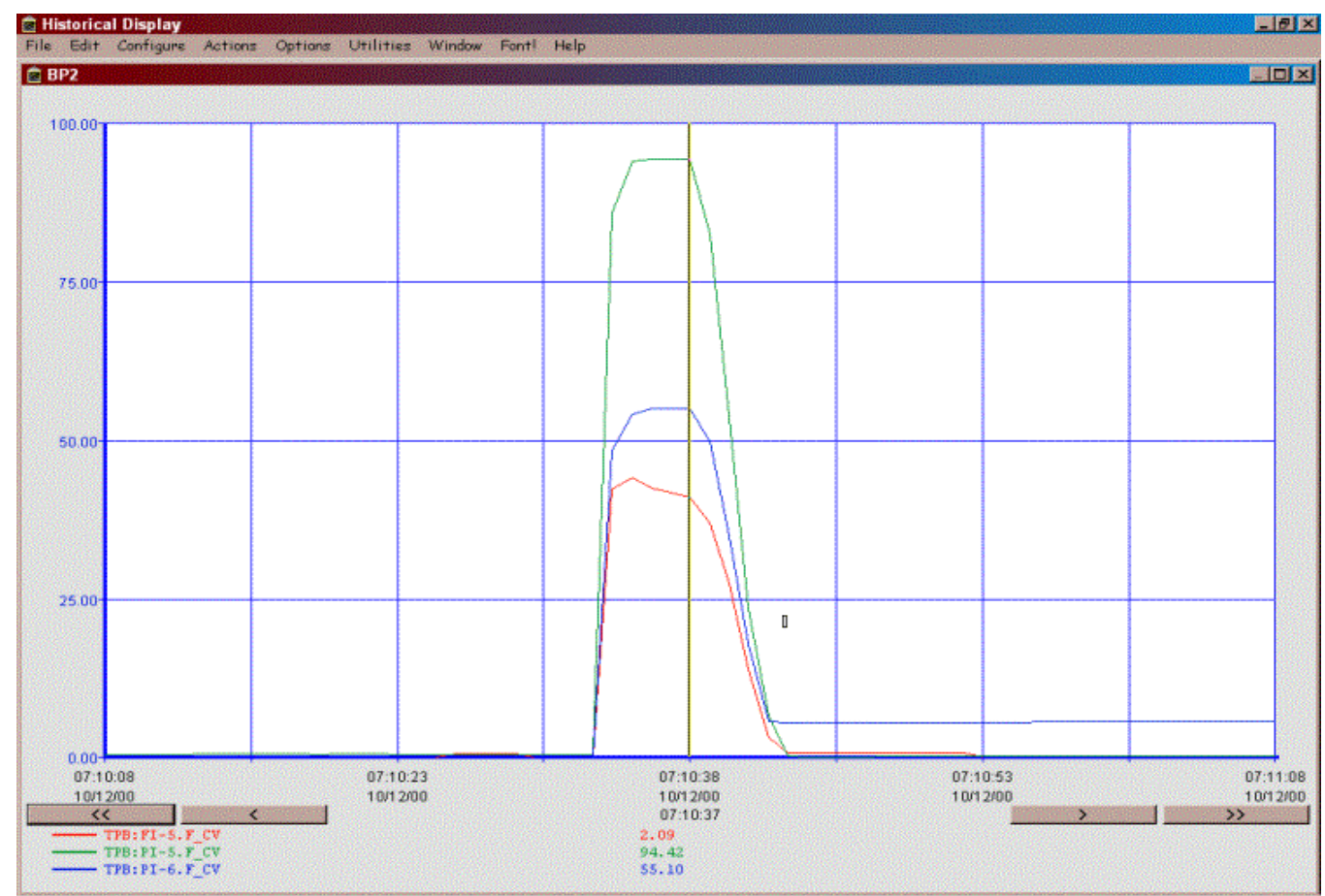

Fig. 40. Slurry concentration loop filter backpulse during first batch concentration. (Green-Gas pressure, 0-100 psi; Blue-Loop pressure, 0-100 psi; Red-Liquid flow, 0-5 L/min)

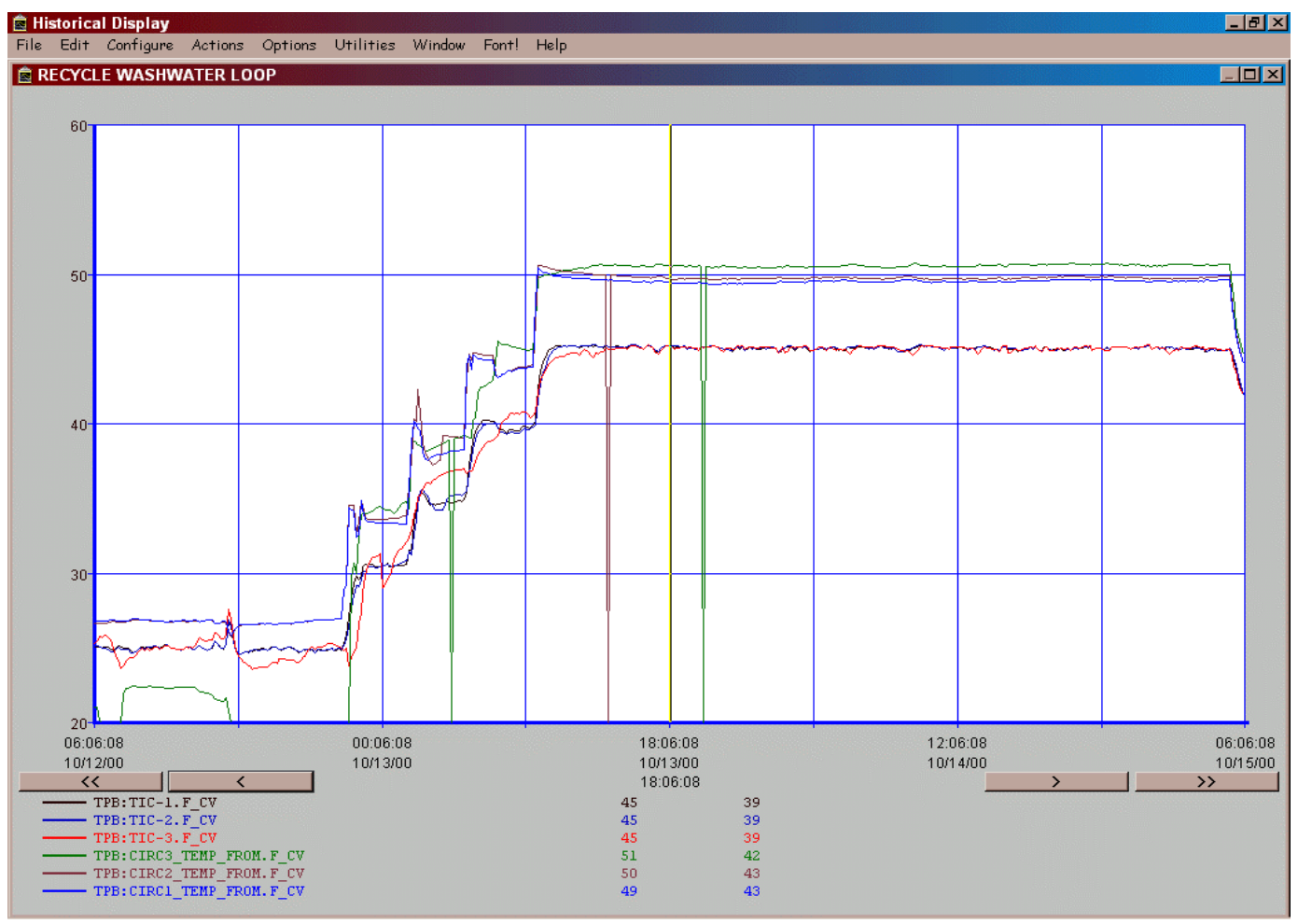

Fig. 41. CSTRs and Slurry Concentrating Tank temperatures during operation at $45^{\circ} \mathrm{C}$. (Black-CSTR 1; Blue-CSTR 2; Red-Slurry Concentrating Tank) 


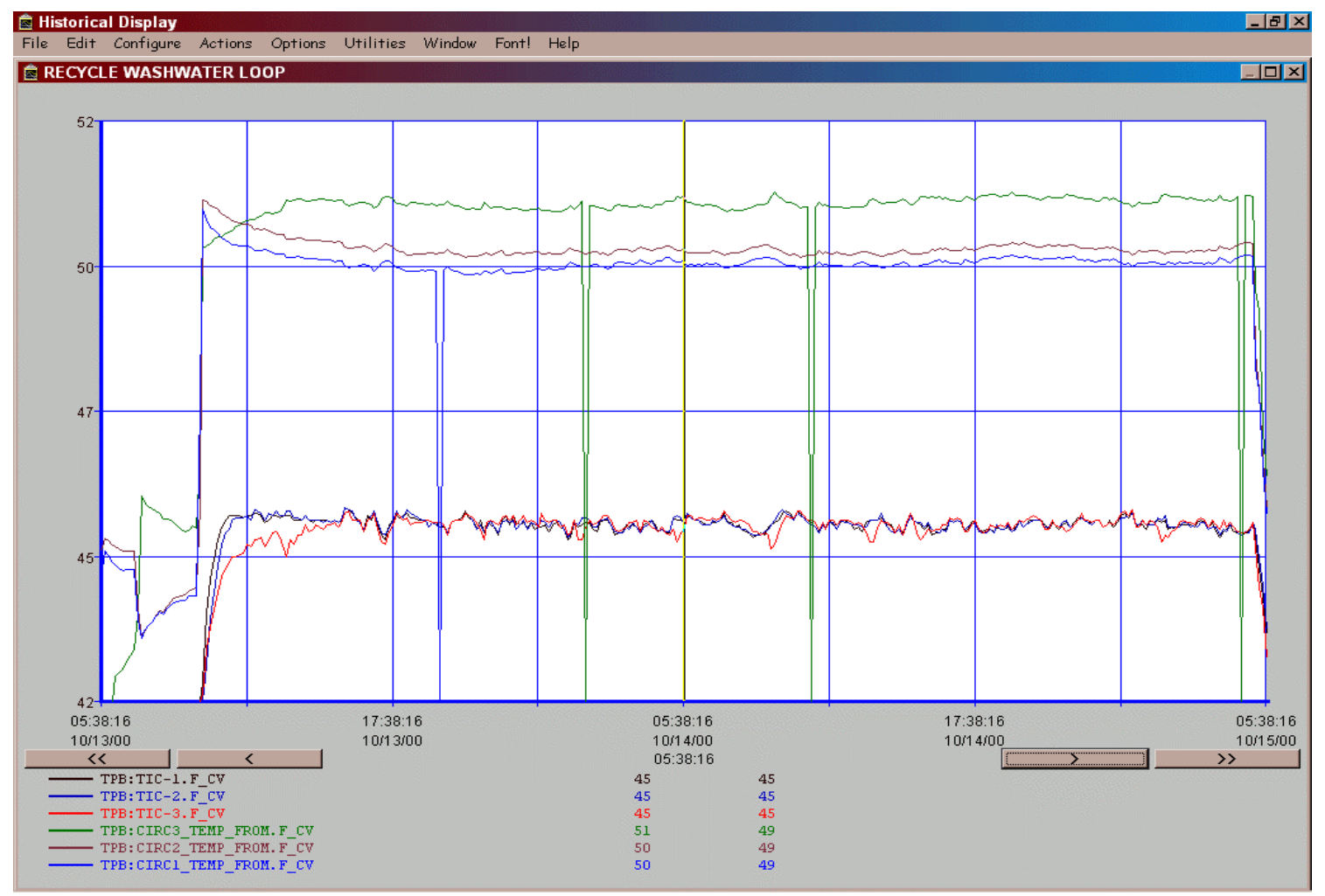

Fig. 42. Close-up view of CSTRs and Slurry Concentrating Tank temperatures during operation at $4^{\circ} \mathbf{C}$. (Black-CSTR 1; Blue-CSTR 2; Red-Slurry Concentrating Tank)

\subsection{SLURRY WASHING}

The goal of washing the concentrated slurries is to remove, by dissolution in water, the excess TPB that was not precipitated with the potassium and cesium. The recovered TPB solution is then recycled to the CSTR 1 for enhanced TPB utilization. Both potassium tetraphenylborate (KTPB) and cesium tetraphenylborate (CsTPB) are insoluble under the dilute conditions; therefore, there is no threat of recycling additional dissolved cesium to the process. The extent of and desirability for recycling TPB will be determined by the end user of the process. Although Test 4 was not a closed-loop test, recycle wash water generated by washing the Test 3 concentrated slurry was used to start the test. A sufficient quantity of NaTPB was added to the wash water to provide the $60 \%$ excess TPB. In all previous tests in which the concentrated slurries were washed with water, the best effort to remove the TPB removed only about $30 \%$ of the needed amount. To provide the $60 \%$ excess, the TPB concentration in the wash water must be $0.033 \mathrm{~mol} / \mathrm{L}$.

The first batch of concentrated slurry in the Slurry Concentrating Tank (about $7 \mathrm{~L}$ at $\sim 10 \mathrm{wt} \%$ solids) was transferred to the Slurry Wash Tank after $78 \mathrm{~h}$ of operation. About $1.5 \mathrm{~L}$ of concentrated slurry was left in the Slurry Concentrating Tank. The second batch was collected over the remaining $52 \mathrm{~h}$ of the test. At the end of the test, the slurries in both CSTRs were pumped from the bottom of the CSTRs to the Slurry Concentrating Tank and then concentrated. Because the recycle wash water tank was full after the process of washing the first batch of slurry, this concentrate batch was water washed in the slurry concentration filtration system and the wash water permeate from the filter was collected in carboys at the concentrator filtrate collection point. Both batches of slurry that were produced in Test 4 were washed with water in steps of 6 to $8 \mathrm{~h}$ for a total of about $24 \mathrm{~h}$ for use in Test 5 . The washing rate was about $20 \mathrm{~mL} / \mathrm{min}$, and about $29 \mathrm{~L}$ of wash water was collected for each batch washed. Samples of wash-water 
filtrates from the cross-flow filter were sent to RMAL for nitrite and TPB analyses. The results are given in Tables 7 and 8 and plotted in Fig. 43. The removal goal was to decrease the nitrite concentration in the wash-water filtrate samples to $0.01 M(440 \mathrm{mg} / \mathrm{L})$. Tables 7 and 8 show that the nitrite concentrations in the last wash-water samples were 721 and $769 \mathrm{mg} / \mathrm{L}$. The concentrations of nitrite and TPB in a sample of the combined wash water from the first batch were 5740 and $1120 \mathrm{mg} / \mathrm{L}$, respectively. The TPB concentration $(1120 \mathrm{mg} / \mathrm{L})$ was only $15 \%$ of the targeted concentration of $7473 \mathrm{mg} / \mathrm{L}$. These results were similar to those obtained for the Test 3 slurry wash. A sample of the composite wash from the second batch has not yet been taken for analysis.

In this test and in previous tests, the expected quantity of TPB to be recovered from the wash water was not achieved. The solubilities of the TPB precipitates of $\mathrm{Na}, \mathrm{K}$, and $\mathrm{Cs}$ are the basis for use of the STTP. ${ }^{7,8}$ The soluble-TPB data for the first batch of slurry concentrate that was washed decreased as the concentration of nitrite decreased. The sodium concentration in the wash filtrate should follow the same trend. For a nitrite concentration of $721 \mathrm{mg} / \mathrm{L}(0.0104 \mathrm{~mol} / \mathrm{L})$, the calculated $\mathrm{Na}^{+}$concentration would be $0.11 \mathrm{~mol} / \mathrm{L}$. If the precipitate had been pure NaTPB, it should have easily gone into solution at that $\mathrm{Na}^{+}$ concentration. (The synthetic recycle wash water has a sodium concentration of about $1.2 \mathrm{M}$ and a NaTPB concentration of $0.033 \mathrm{M}$, or about $11,300 \mathrm{ppm}$.) It appears that the solubility of NaTPB has been reduced due to some chemical condition or component of the concentrated slurry. In lab-scale tests at Savannah River, IITB52 proved to be the most effective antifoam/defoam agent; however, the test data indicated that TPB wash recovery was poor. For example, when no antifoam was present during washing, about $60 \%$ of the excess TPB was dissolved. ${ }^{9}$ However, when IITB52 was used, only $12.7 \%$ of the excess TPB was recovered.

Table 7. Results for Test 4 Batch 1 slurry washing at $20 \mathrm{~mL} / \mathrm{min}$

\begin{tabular}{ccccc}
\hline $\begin{array}{c}\text { Washing } \\
\text { volume } \\
(\mathrm{L})\end{array}$ & $\begin{array}{c}\text { Washing } \\
\text { time } \\
(\mathrm{h})\end{array}$ & $\begin{array}{c}\text { Wash tank } \\
\text { filtrate } \\
\text { sample ID }\end{array}$ & $\begin{array}{c}\text { RMAL } \\
\mathrm{NO}_{2}^{-} \\
(\mathrm{mg} / \mathrm{L})\end{array}$ & $\begin{array}{c}\text { RMAL } \\
\text { NaTPB } \\
(\mathrm{mg} / \mathrm{L})\end{array}$ \\
\hline 4.8 & 4 & $\mathrm{~T} 4 \mathrm{~W}-1$ & 9,740 & 1,120 \\
9.6 & 8 & T4W-2 & 5,810 & 1,110 \\
14.4 & 12 & T4W-3 & 3,330 & 1,010 \\
19.2 & 16 & T4W-4 & 1,870 & 784 \\
24 & 20 & T4W-5 & 1,180 & 810 \\
28.8 & 24 & T4W-6 & 721 & 689 \\
\multicolumn{5}{c}{ Composite from recycle wash water tank } \\
\hline
\end{tabular}

Table 8. Results for Test 4 Batch 2 slurry washing at $20 \mathrm{~mL} / \mathrm{min}$

\begin{tabular}{ccccc}
\hline $\begin{array}{c}\text { Washing } \\
\text { volume } \\
(\mathrm{L})\end{array}$ & $\begin{array}{c}\text { Washing } \\
\text { time } \\
(\mathrm{h})\end{array}$ & $\begin{array}{c}\text { Conc. tank } \\
\text { filtrate } \\
\text { sample ID }\end{array}$ & $\begin{array}{c}\text { RMAL } \\
\mathrm{NO}_{2}^{-} \\
(\mathrm{mg} / \mathrm{L})\end{array}$ & $\begin{array}{c}\text { RMAL } \\
\text { NaTPB } \\
(\mathrm{mg} / \mathrm{L})\end{array}$ \\
\hline 4.8 & 4 & TW4H-1 & 13,200 & 526 \\
9.6 & 8 & TW4H-2 & 6,720 & 1,020 \\
14.4 & 12 & TW4H-3 & 3,580 & 965 \\
19.2 & 16 & TW4H-4 & 2,460 & 1,150 \\
24 & 20 & TW4H-5 & 1,330 & 1,030 \\
28.8 & 24 & TW4H-6 & 769 & 1,090 \\
\hline
\end{tabular}




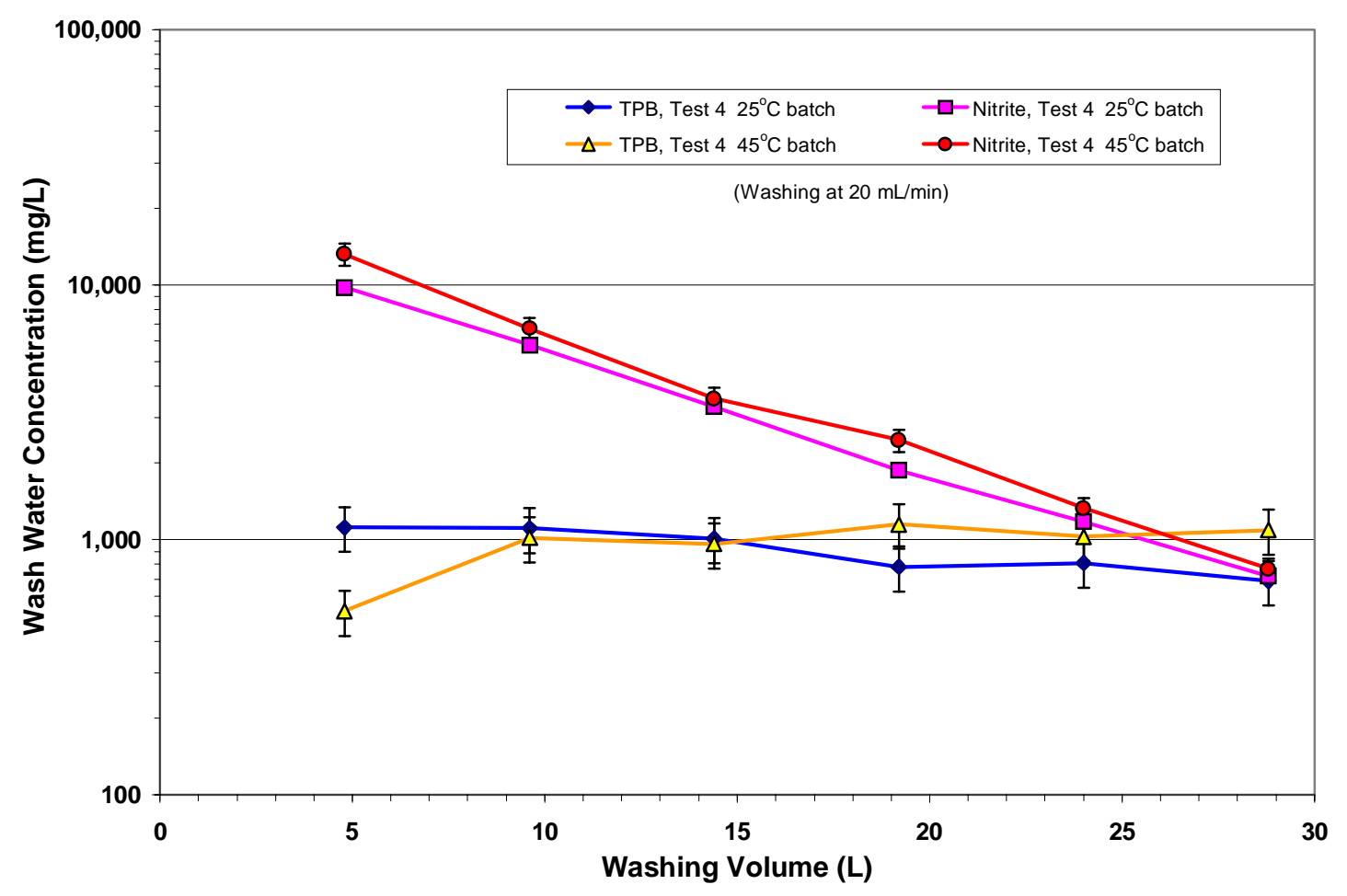

Fig. 43. Nitrite and TPB concentrations during Test 4 slurry washing $\left(25^{\circ} \mathrm{C}\right.$ batch and $45^{\circ} \mathrm{C}$ batch).

A mole accountability analysis of K, Cs, and TPB for each of the CSTR tests was performed to determine the available moles of TPB not associated with K and Cs in each batch of concentrated slurry that was washed (see Table 9). The analyses accounted for the moles of K, Cs, and TPB in the CSTRs and Slurry Concentrating Tank before each test and subsequently the moles of each constituent added during each test. It accounted for the moles of constituents that were transferred to the Slurry Washing Tank and the moles of each that were left in the concentrating system. In Test 1a, for example, all the slurry in the concentrating system and in both CSTRs was transferred to the Slurry Washing Tank and washed. In Test 1a, as well as Tests 2 and 3, the method of starting the test was to first fill the CSTRs with the $4.7 \mathrm{M} \mathrm{Na}^{+}$water diluted salt feed (an additional $3 \mathrm{~L}$ was added to the Slurry Concentrating Tank). Consequently, the initial batches of concentrated slurry had TPB/(potassium + cesium) mole ratios that were much lower than any subsequent batches prepared, as in Tests 2 and 4 . Mole accounting for Test 1a found that the concentrated slurry contained $1.677 \mathrm{~mol} \mathrm{~K}^{+}, 0.0124 \mathrm{~mol} \mathrm{Cs}^{+}$, and $2.173 \mathrm{~mol}$ TPB. The available TPB (that was not precipitated by potassium and cesium) was $0.484 \mathrm{~mol}$. The concentration of TPB in the slurry wash water was analytically determined by HPLC to be $0.0047 \mathrm{~mol} / \mathrm{L}$. The $12.3 \mathrm{~L}$ of wash water contained 0.058 mol TPB. Only $12 \%$ of the available TPB in the slurry concentrate was recovered. If all the available TPB had been recovered, its concentration in the wash water would have been $0.039 \mathrm{~mol} / \mathrm{L}$.

The slurries were left stirring in the CSTRs after Test 3 for use in the startup of Test 4. Only the concentrated slurry in the concentrating system was transferred to the Slurry Washing Tank. The K, Cs, and TPB analyses showed that $0.33 \mathrm{~mol}$ of NaTPB was available for dissolution and about $29 \%$ $(0.095 \mathrm{~mol})$ was recovered. At the start of Test 2 , it was found that the recycle wash water from Test 1 
did not have the needed TPB concentration to provide a 60\% excess. To compensate, an extra TPB feed supply was added that was pumped into a tee connected to the MST/water supply line. The extra TPB was added at a rate of $0.40 \mathrm{~mL} / \mathrm{min}$ and provided the $60 \%$ excess. The recycle wash water in the hot cell was added at $6.8 \mathrm{~mL} / \mathrm{min}$ for the first $30 \mathrm{~h}$ of the test using about $12.4 \mathrm{~L}$; its TPB concentration was 0.0047 . For the next $26 \mathrm{~h}$, simulated recycle wash water containing $0.033 \mathrm{M}$ TPB was added. At $56 \mathrm{~h}$ testing, about 5 of the $7 \mathrm{~L}$ in the concentrating system was transferred to the Slurry Washing Tank for water washing. This batch contained about $0.86 \mathrm{~mol}$ of available TPB. The $\mathrm{K}^{+}$concentration in the salt feed was $0.0163 M$ rather than $0.0171 M$ because of the addition of the large volume of catalyst solution that was used in the test. The water-washing rate was $10 \mathrm{~mL} / \mathrm{min}$, and $18.6 \mathrm{~L}$ of recycle wash water was collected. The TPB concentration was only $0.0039 \mathrm{~mol} / \mathrm{L}$; only $9 \%(0.072 \mathrm{~mol})$ was recovered. The mole accounting method estimates that 18,19 , and $20 \%$ were recovered in the next three batches. These results are twice as good as those for first batch—but still very low recovery.

Mole analysis of the washed batches in Test 4 found that TPB recovery was still inefficient, only 10 and $11 \%$ removal. The recoveries are similar to those for Test $1 \mathrm{a}$ and the first batch for Test 2 . The mixing speed in Tests 1a, 2, and 4 was about 600 to $700 \mathrm{rpm}$. Antifoam B-52 was used in Test 4 but not in Tests 1a and 2. The best TPB recovery (29\%) was obtained in Test 3 in which B-52 was used, but the mixing speed in the Slurry Washing Tank was 1200 to $1400 \mathrm{rpm}$ (about twice as fast as in the other tests), which could have aided the improved recovery. Three of the batches of concentrated slurry in Test 2 removed twice as much of the available TPB as was removed in Test 1a, Test 4, and the first batch of Test 2. This seems to indicate that B-52 may have inhibited the recovery process. It is obvious that the recoveries in all these test were much less than desired, and additional research is need to resolve the problem.

Table 9. NaTPB recovery in slurry washing process in CSTR tests

\begin{tabular}{|c|c|c|c|c|c|c|c|c|}
\hline Test & $\begin{array}{l}\text { Wash } \\
\text { cycle }\end{array}$ & $\begin{array}{l}\text { Time } \\
\text { (h) }\end{array}$ & $\begin{array}{c}\text { Wash } \\
\text { rate } \\
(\mathrm{mL} / \mathrm{min})\end{array}$ & $\begin{array}{c}\text { Available } \\
\mathrm{TPB}^{a} \\
(\mathrm{~mol})\end{array}$ & $\begin{array}{l}\mathrm{RWW}^{b} \\
\text { (L) }\end{array}$ & $\begin{array}{c}\text { TPB } \\
\text { recovered } \\
(\mathrm{mol})\end{array}$ & $\begin{array}{c}\mathrm{TPB}^{c} \\
(\mathrm{~mol} / \mathrm{L})\end{array}$ & $\begin{array}{c}\text { Percent } \\
\text { recovered }^{d}\end{array}$ \\
\hline $1 \mathrm{a}$ & $1^{e}$ & 16 & 10 & 0.48 & 12.3 & 0.058 & 0.0047 & 12 \\
\hline 2 & 1 & 31 & 10 & 0.86 & 18.6 & 0.072 & 0.0039 & 9 \\
\hline 2 & 2 & 28 & 15 & 0.63 & 25 & 0.115 & 0.0046 & 18 \\
\hline 2 & 3 & 43 & 8 & 0.76 & 20.6 & 0.148 & 0.0072 & 19 \\
\hline 2 & 4 & 44 & 5 & 0.69 & 13.2 & 0.138 & 0.0105 & 20 \\
\hline 3 & $1^{f}$ & 32 & 15 & 0.33 & 28.8 & 0.095 & 0.0033 & 29 \\
\hline 4 & $1^{g}$ & 30 & 20 & 1.09 & 35.4 & 0.117 & 0.0033 & 11 \\
\hline 4 & $2^{g}$ & 29 & 20 & 1.11 & 34.6 & 0.111 & 0.0032 & 10 \\
\hline
\end{tabular}

${ }^{a}$ Moles of excess TPB as NaTPB in batch available to be dissolved by water washing.

${ }^{b} \mathrm{RWW}=$ recycle wash water.

${ }^{c}$ Testing goal was to obtain enough TBP in recycle wash water to provide a $60 \%$ excess $(\sim 0.033 \mathrm{~mol} / \mathrm{L})$.

${ }^{d}(\mathrm{~mol} \mathrm{TPB}$ recovered $) /(\mathrm{mol}$ available TPB in batch $)$.

${ }^{e}$ Recycle wash water used in Test 2.

${ }^{f}$ Recycle wash water used in Test 4.

${ }^{g}$ Recycle wash water to be used in Test 5 . 


\section{CONCLUSIONS}

Test 4 was a 130.3-h test (actual operating time of $125.5 \mathrm{~h}$ ) conducted to verify that acceptable STTP performance could be maintained while the TPB was actively decomposing. An improved catalyst mixture, which provided process concentrations of $7.8 \mathrm{mg} / \mathrm{L} \mathrm{Pd}(0), 85 \mathrm{mg} / \mathrm{L} \mathrm{Hg}(\mathrm{II}), 500 \mathrm{mg} / \mathrm{L}$ phenylboronic acid (1PB), and $720 \mathrm{mg} / \mathrm{L}$ benzene, was added continuously to CSTR 1 . The process temperature was maintained at $25^{\circ} \mathrm{C}$ for the first $76 \mathrm{~h}$ of operation while concentrating the slurry in the Slurry Concentrating Tank to about $10 \mathrm{wt} \%$. Over the next $13 \mathrm{~h}$, after the concentrated slurry had been transferred to the Slurry Washing Tank, the temperature of the slurries in the system vessels was increased in increments of $5^{\circ} \mathrm{C}$ to $45^{\circ} \mathrm{C}$, where it was maintained for the remainder of the test. Decomposition of TPB was determined by HPLC analyses of the CSTRs and Slurry Concentrating Tank filtrates and by on-line FTIR measurement of benzene in the vapor space of each vessel. Foam suppressant IIT B52 was added to the system vessels to minimize foam formation.

The ${ }^{137}$ Cs DFs for the filtrates from the Slurry Concentrating Tank were $>56,000$, with some values as high as 650,000. The decontamination chemistry exceeded the DF goal of 40,000 or 99.998\% removal. Moreover, DFs for CSTR 1 and CSTR 2 filtrates were also very high, ranging from 21,000 to 140,000 , with most being $>30,000$. The results indicated that the required cesium DF could be maintained despite the elevated temperature and high rate of TPB decomposition. The MST effectively removed the strontium, providing DFs of 100 to 200 for the duration of the test. The SRS WAC goal was 26 , or $96 \%$ removal.

Efforts to remove the excess TPB by washing the produced slurries with water were not very successful. Only about $10-11 \%$ of the excess TPB that was calculated to be in the sodium form was removed. This is about the same percentage as was removed in Test $1 \mathrm{a}$ and the first batch of Test 2 , in which the mixing speed in the Slurry Washing Tank was about 600 to $700 \mathrm{rpm}$. Based on these results, it does not appear that the use of IIT-B52 in Test 4 inhibited IIT-TPB recovery. Furthermore, in Test 3, B52 was used and three times more TPB was recovered than was recovered in Tests 1a, 2, and 4. However, a higher mixing speed (1200 to $1400 \mathrm{rpm}$ ) was used in Test 3, which may have enhanced the recovery. About 18 to $20 \%$ of the excess TPB was recovered in the last three of the four batches of concentrated slurry washed in Test 2 . No B-52 was used in Test 2 . The recovery data do not yet make it clear as to whether B-52 enhanced or slowed the NaTPB dissolution process during washing. It is obvious that the recoveries in all these test were much less than desirable and additional research is need to resolved the problem.

Problems with the operation of the equipment during the test were minimal, especially in the slurry concentration cross-flow filtration system, at both 25 and $45^{\circ} \mathrm{C}$. Backpulsing the filter worked well when it was required. The benzene monitoring system also performed well, although minor program adjustments were required to remove some interference that was experienced during operation. The primary problems involved the feed systems, mainly the Catalyst/MST feed, which repeatedly plugged due to the $\mathrm{Hg}, \mathrm{MST}$, and Pd interactions and resulted in plugging of the feed line. This problem made it difficult to suspend the slurry mixture in the feed tank. The combined process fluids in CSTR 1 also presented plugging problems in the sample valve between CSTR 1 and CSTR 2, requiring the valve to be changed out during the first day of the test. However, these setbacks were resolved quickly and efficiently by the operating personnel without any significant impact on the overall process or the accuracy of the operating data. 


\section{REFERENCES}

1. D. D. Lee and J. L. Collins, Continuous-Flow Stirred-Tank Reactor 20-L Demonstration Test: Final Report, ORNL/TM-1999/234, February 2000.

2. D. D. Lee and J. L. Collins, Test Results for CSTR Test 3, CERS/SR/TPB/011, Sept. 25, 2000.

3. Mark Barnes et al., Recommendation of Catalyst System and Delivery for ORNL 20-L Testing, SRT-LWP-2000-00126, August 2000.

4. J. L. Collins and D. D. Lee, Preparation of Simulated Waste Solutions for CSTR Tests, CERS/SR/TPB/005, Rev. 3, Oct. 9, 2000.

5. J. L. Collins, Sampling Plan and Procedure (CSTR Test 4), CERS/SR/TPB/006, Rev. 1, Aug. 2, 2000.

6. D. D. Lee, Test Plan for CSTR Test 4, CERS/SR/TPB/010, Sept. 25, 2000.

7. R. A. Peterson and J. O. Burgess, Co-precipitation and Solubility Studies of Cesium, Potassium, and Sodium Tetraphenylborate, WSRC-TR-99-00216, June 24, 1999.

8. S. M. Serkiz, J. D. Ginn, and A. R. Jurgensen, Tetraphenylborate Solubility in High Ionic Strength Salt Solutions, WSRC-TR98-00103, Rev. 0, April 3, 1998.

9. M. A. Baich, D. P. Lambert, and P. R. Monson, Laboratory Scale Antifoam Studies for the STTPB Process (U), WSRC-TR-2000-00261, Rev. 0, Oct. 24, 2000. 


\section{INTERNAL DISTRIBUTION}

ORNL/TM-2001/8

$\begin{aligned} 1 . & \text { K. K. Anderson } & 22 . & \text { C. P. McGinnis } \\ 2 . & \text { P. V. Bonnesen } & 23 . & \text { L. E. McNeese } \\ 3 . & \text { D. A. Bostick } & 24 . & \text { S. A. Richardson } \\ 4-8 . & \text { J. L. Collins } & 25 . & \text { S. M. Robinson } \\ 9 . & \text { B. S. Evans } & 26 . & \text { P. A. Taylor } \\ 10 . & \text { R. D. Hunt } & 27 . & \text { J. R. Travis } \\ 11 . & \text { H. L. Jennings } & 28-30 . & \text { J. F. Walker } \\ 12 . & \text { R. T. Jubin } & 31 . & \text { T. D. Welch } \\ 13-15 . & \text { T. E. Kent } & 32 . & \text { ORNL Central Research Library } \\ 16 . & \text { L. N. Klatt } & 33 . & \text { Laboratory Records, RC } \\ 17-21 . & \text { D. D. Lee } & 34 . & \text { Laboratory Records, OSTI }\end{aligned}$

\section{EXTERNAL DISTRIBUTION}

35. M. J. Barnes, Westinghouse Savannah River Company, P.O. Box 616, 773-A, Room B132, Aiken, SC 29808

36. J. M. Boncella, Dept. of Chemistry and Center for Catalysis, University of Florida, Gainesville, FL 32611-7200

37. L. D. Bustard, Sandia National Laboratories, P.O. Box 5800, MS: 0728, Albuquerque, NM 87185-5800

38. J. T. Carter, Westinghouse Savannah River Company, P.O. Box 616, 704-3N, Room S151, Aiken, SC 29808

39. N. F. Chapman, Westinghouse Savannah River Company, Building 704-3N, Room S151, Aiken, SC 29808

40. E. J. Cruz, U.S. Department of Energy, Richland Operations Office, P.O. Box 550, MSIN: H6-60, Richland, WA 99352

41. F. Damerow, West Valley Nuclear Services, P.O. Box 191, West Valley, NY 14171

42. J. L. Drake, Jr., U.S. Department of Energy, 10282 Rock Springs Road, West Valley, NY 14171

43. M. C. Duff, Savannah River Ecology Laboratory, University of Georgia, Aiken, SC 29802

44. Herbert H. Elder, Westinghouse Savannah River Company, P.O. Box 616, 704-196N, Room N411, Aiken, SC 29808

45. Samuel D. Fink, Westinghouse Savannah River Company, P.O. Box 616, 773-A, Room B112, Aiken, SC 29808 
46. Kurt Gerdes, TFA Headquarters Program Lead, DOE Office of Science and Technology, 19901 Germantown Rd., 1154 Cloverleaf Building, Germantown, MD 20874-1290

47. P. W. Gibbons, Numatec Hanford Corporation, P.O. Box 1970, MS: H5-61, Richland, WA 99352

48. Roger L. Gilchrist, Pacific Northwest National Laboratory, P.O. Box 999, MS:K9-91, Richland, WA 99352

49. T. S. Gutmann, U.S. Department of Energy, Savannah River Operations Office, P.O. Box A, Aiken, SC 29802

50. H. D. Harmon, Tanks Focus Area Salt Processing Program, P.O. Box 616, 704-3N, Room N111, Aiken, SC 29808

51. E. W. Holtzscheiter, Westinghouse Savannah River Company, Savannah River Technology Center, Building 773-A, Room A-230, MS: 28, Aiken, SC 29802

52. J. O. Honeyman, Lockheed Martin Hanford Corporation, P.O. Box 1500, MS: G3-21, Richland, WA 99352

53. R. A. Jacobs, Westinghouse Savannah River Company, Building 704-3N, Room S311, Aiken, SC 29808

54. Jim Jewett, Numatec Hanford Corporation, P.O. Box 1970, Richland, WA 99352

55. R. T. Jones, Westinghouse Savannah River Company, P.O. Box 616, 704-3N, Room S122, Aiken, SC 29808.

56. R. B. King, Dept. of Chemistry, University of Georgia, Athens, GA 30602-2556

57. R. A. Kirkbride, Numatec Hanford Corporation, P.O. Box 1970, MS: H5-27, Richland, WA 99352

58. C. L. Leung, Westinghouse Savannah River Company, P.O. Box 616, 704-3N, Room S151, Aiken, SC 29808

59. K. A. Lockie, U.S. Department of Energy, Idaho Operations Office, 750 DOE Place, MS: 1145, Idaho Falls, ID 83402

60. C. S. Louie, U.S. Department of Energy, Richland Operations Office, P.O. Box 550, MSIN: B4-55, Richland, WA 99352

61. J. W. McCullough, Jr., U.S. Department of Energy, Savannah River Operations Office, P.O. Box A, Building 704-3N, Room N380, Aiken, SC 29802

62. J. P. Morin, Westinghouse Savannah River Company, Savannah River Technology Center, P.O. Box 616, Building 703-H, Room 119, Aiken, SC 29808

63. L. M. Nelson, Westinghouse Savannah River Company, P.O. Box 616, 773-43A, Room 222, Aiken, SC 29808 
64. J. R. Noble-Dial, U.S. Department of Energy, Oak Ridge Operations Office, P.O. Box 2001, Oak Ridge, TN 37830-8620

65. Arlin Olson, Idaho National Engineering and Environmental Laboratory, Building 637, MS-5218, Idaho Falls, ID 83415-5218

66. L. M. Papouchado, Westinghouse Savannah River Company, P.O. Box 616, 773-A, Room A-263, Aiken, SC 29808

67. S. F. Piccolo, Westinghouse Savannah River Company, Building 703-H, Room: 118, Aiken, SC 29808

68. J. M. Reynolds II, U.S. Department of Energy, Savannah River Operations Office, P.O. Box A, Building 704-3N, Room N152, Aiken, SC 29802

69. Jim Rindfleisch, Idaho National Engineering and Environmental Laboratory, Building 637, MS: 5218, Idaho Falls, ID 83415-5218

70. Lynne Roeder-Smith, TFA Technical Team Communications, Pacific Northwest National Laboratory, P.O. Box 999, MSIN: K9-69, Richland, WA 99352

71. W. W. Schulz, 12704 Sandia Ridge Place NE, Albuquerque, NM 87111

72. S. N. Schlahta, Tanks Focus Area Salt Processing Program, P.O. Box 616, 704-3N, Room N302, Aiken, SC 29808

73. Patricia C. Suggs, U.S. Department of Energy, Savannah River Operations Office, P.O. Box A, Building 704-3N, Room N380, Aiken, SC 29802

74. J. L. Swanson, 1318 Cottonwood, Richland, WA 99352

75. W. L. Tamosaitis, Westinghouse Savannah River Company, P.O. Box 616, 773-A, Room A-231, Aiken, SC 29808

76. Larry Tavlarides, Syracuse University, Dept. of Chemical Engineering \& Materials Science, 334 Hinds Hall, Syracuse, NY 13244-1190

77. M. T. Terry, Los Alamos National Laboratory, P.O. Box 999, MSIN: K9-69, Richland, WA 99352

78. T. R. Thomas, Lockheed Martin Idaho Technologies Company, P.O. Box 1625, MSIN: 3458, Idaho Falls, ID 83415-3423

79. T. A. Todd, Idaho National Engineering and Environmental Laboratory, Building 637, MS-5218, Idaho Falls, ID 83415-5218

80. J. H. Valentine, Bechtel BWXT Idaho, Inc., P.O. Box 1625, MS: 3211, Idaho Falls, ID $83415-3100$

81. George Vandegrift, Argonne National Laboratory, Building 205, 9700 South Cass Avenue, Argonne, IL 60439 
82. J. H. Westsik, Pacific Northwest National Laboratory, P.O. Box 999, MS: K9-91, Richland, WA 99352

83. W. R. Wilmarth, Westinghouse Savannah River Company, P.O. Box 616, 773-42A, Room 153, Aiken, SC 29808

84. P. E. Woodall, U.S. Department of Energy, Idaho Operations Office, 750 DOE Place, MS: 1145, Idaho Falls, ID 83402

85-92. Tanks Focus Area Technical Team, c/o B. J. Williams, Pacific Northwest National Laboratory, P.O. Box 999, MSIN: K9-69, Richland, WA 99352

93. Tanks Focus Area Field Lead, c/o T. P. Pietrok, U.S. Department of Energy, Richland Operations Office, P.O. Box 550, MS: K8-50, Richland, WA 99352 